\title{
Surface-Water and Groundwater Interactions along the Withlacoochee River, West-Central Florida
}

By J.T. Trommer, D.K. Yobbi, and W.S. McBride

Prepared in cooperation with the

Southwest Florida Water Management District

Scientific Investigations Report 2009-5124 


\title{
U.S. Department of the Interior \\ KEN SALAZAR, Secretary
}

\author{
U.S. Geological Survey \\ Suzette M. Kimball, Acting Director
}

U.S. Geological Survey, Reston, Virginia: 2009

For more information on the USGS - the Federal source for science about the Earth, its natural and living resources, natural hazards, and the environment, visit http://www.usgs.gov or call 1-888-ASK-USGS

For an overview of USGS information products, including maps, imagery, and publications, visit http://www.usgs.gov/pubprod

To order this and other USGS information products, visit http://store.usgs.gov

Any use of trade, product, or firm names is for descriptive purposes only and does not imply endorsement by the U.S. Government.

Although this report is in the public domain, permission must be secured from the individual copyright owners to reproduce any copyrighted materials contained within this report.

Suggested citation:

Trommer, J.T., Yobbi, D.K., and McBride, W.S., 2009, Surface-Water and Groundwater Interactions along the Withlacoochee River, West-Central Florida: U.S. Geological Survey Scientific Investigations Report 2009-5124, 47 p. 


\section{Contents}

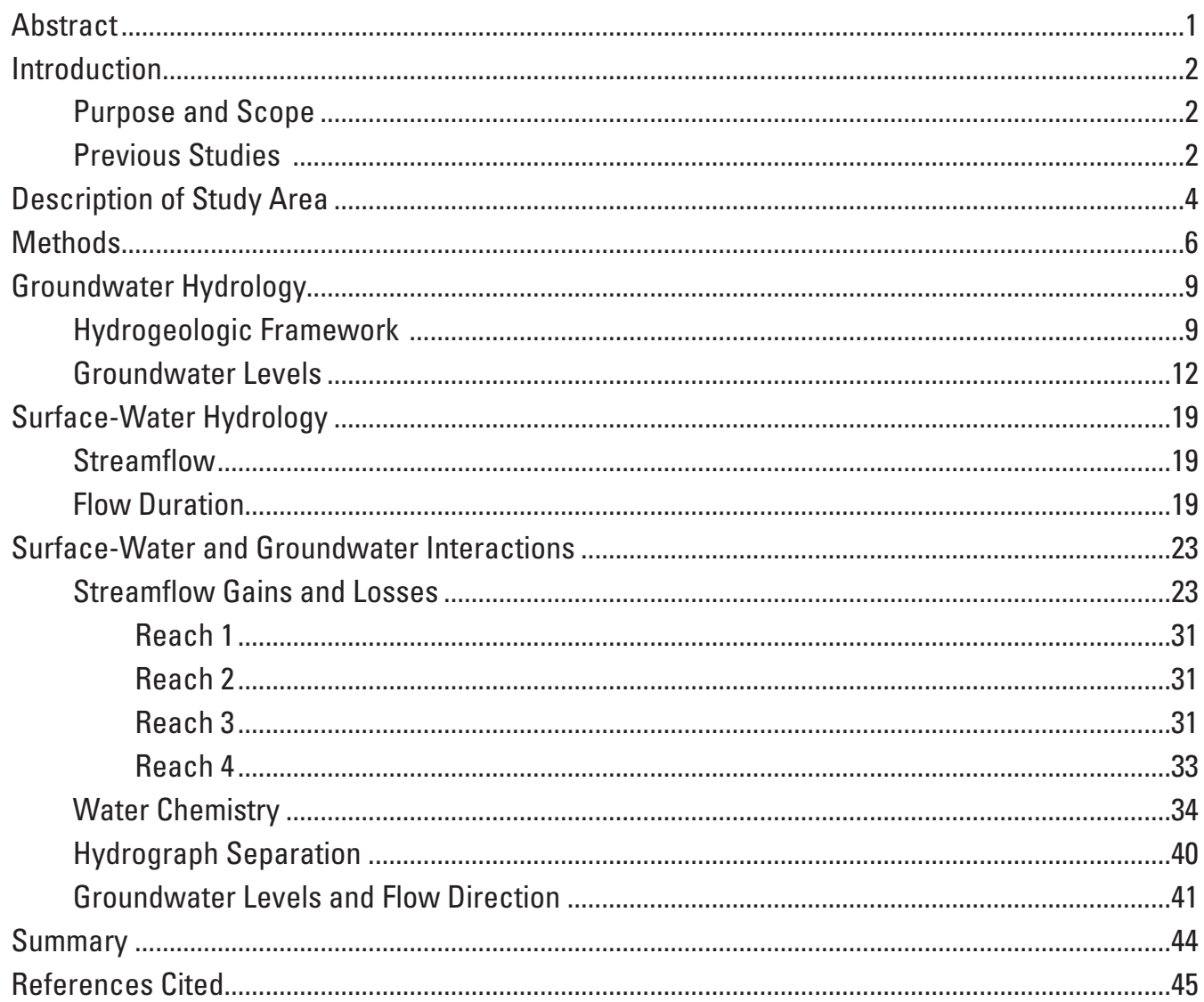

\section{Figures}

1-4. Maps showing-

1. Location of the Withlacoochee River watershed, west-central Florida .....................3

2. Location of the study area and the surface-water data collection network.............5

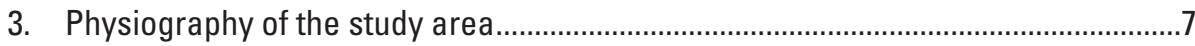

4. Location of seismic-reflection survey areas along the Withlacoochee River ..........8

5. Generalized hydrostratigraphy for the study area .....................................................10

6. Map showing geology at or near land surface, west-central Florida .............................11

7. Map showing location of the paired well sites and Upper Floridan aquifer wells

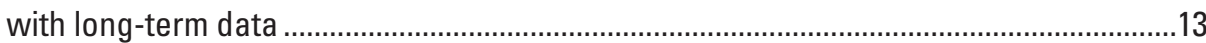

8. Graph showing transient nature of surficial aquifer water levels at the Green Swamp L-11M well site.

9. Graphs showing cumulative water level in relation to time for the four Upper Floridan aquifer wells with long-term data

10. Maps showing potentiometric surface of the Upper Floridan aquifer in the Withlacoochee River watershed and adjacent areas, September 2005 and May 2006 
11. Map showing difference in the potentiometric surface of the Upper Floridan aquifer in the Withlacoochee River watershed and adjacent areas between September 2005 and May 2006.

12-14. Graphs showing-

12. Daily mean discharge at the Withlacoochee River near Holder and at Trilby stations, and at the Withlacoochee River near Dade City and Cumpressco stations, 2004-06 water years

13. Cumulative daily mean streamflow in relation to time for the Withlacoochee River near Cumpressco, at Trilby, and near Holder stations .22

14. Duration curves of daily mean discharge at the Withlacoochee River near Holder, at Trilby, near Dade City, and near Cumpressco stations for the period between 1967 and 2006, and the study period (2004-06)...

15. Map showing location of streamflow measurement sites and seepage reaches ..........25

16. Graph showing streamflow balance for the Withlacoochee River near Holder station ..........30

17. Map showing generalized patterns of river and aquifer interaction, and net seepage gains and losses for each subreach along the Withlacoochee River 32

18. Graphs showing downstream change in water chemistry along the Withlacoochee River during dry conditions, March 2004. .36

19. Piper diagram showing water chemistry at eight river sites, two tributary sites, two springs, and one Upper Floridan aquifer groundwater reference site in the Withlacoochee River watershed during low flow conditions in 2004.

20. Graph showing relation between the ratio of strontium-87 to strontium-86 and the inverse of the concentration of strontium in samples from the Withlacoochee River sites, springs, and groundwater reference wells

21. Graph showing base flow calculated using the hydrograph separation (HYSEP) method with the fixed interval, sliding interval, and local minimum solutions; the conductivity mass-balance method; and the calibrated HYSEP method at the Cumpressco, Dade City, Croom, and Holder gaging stations.

22. Diagram showing groundwater flow at the ROMP WR6 Withlacoochee River transect during the wet season, September 2005, and the dry season, May 2006 43

\section{Tables}

1. Surface-water data collection sites. 6

2. Groundwater data collection sites with paired deep and shallow wells.........................14

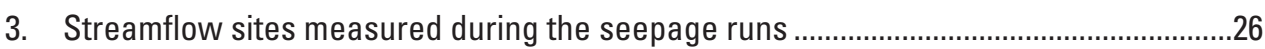

4. Streamflow balance and specific conductance of water for the May 2004 seepage run

5. Streamflow balance and specific conductance of water for the April 2005 seepage run

6. Streamflow balance and specific conductance of water for the April 2006 seepage run

7. Summary of net seepage gains and losses for the 20 subreaches along the Withlacoochee River.

8. Water-quality data at seven successive downstream locations on the Withlacoochee River and at two selected tributaries, 2004.

9. Water-quality data for groundwater sites

10. Mean concentration of selected water-quality constituents at eight Withlacoochee River gaging stations for the period of record

11. Base flow estimated by hydrograph separation methods for 1983-2006 


\section{Conversion factors}

\begin{tabular}{|c|c|c|}
\hline Multiply & By & To obtain \\
\hline \multicolumn{3}{|c|}{ Length } \\
\hline inch (in.) & 25.4 & millimeter (mm) \\
\hline foot $(\mathrm{ft})$ & 0.3048 & meter $(\mathrm{m})$ \\
\hline mile (mi) & 1.609 & kilometer (km) \\
\hline \multicolumn{3}{|c|}{ Area } \\
\hline square mile $\left(\mathrm{mi}^{2}\right)$ & 2.590 & square kilometer $\left(\mathrm{km}^{2}\right)$ \\
\hline \multicolumn{3}{|c|}{ Flow rate } \\
\hline cubic foot per second $\left(\mathrm{ft}^{3} / \mathrm{s}\right)$ & 0.02832 & cubic meter per second $\left(\mathrm{m}^{3} / \mathrm{s}\right)$ \\
\hline cubic foot per second per mile $\left[\left(\mathrm{ft}^{3} / \mathrm{s}\right) / \mathrm{mi}\right]$ & 0.0176 & cubic meter per second per kilometer $\left.\left(\mathrm{m}^{3} / \mathrm{s}\right) / \mathrm{km}\right]$ \\
\hline cubic foot per day $\left(\mathrm{ft}^{3} / \mathrm{d}\right)$ & 0.02832 & cubic meter per day $\left(\mathrm{m}^{3} / \mathrm{d}\right)$ \\
\hline inch per year (in/yr) & 25.4 & millimeter per year (mm/yr) \\
\hline \multicolumn{3}{|c|}{ Hydraulic gradient } \\
\hline foot per mile (ft/mi) & 0.1894 & meter per kilometer $(\mathrm{m} / \mathrm{km})$ \\
\hline
\end{tabular}

\section{Acronyms}

$\begin{array}{ll}\text { ADCP } & \text { Acoustic Doppler current profiler } \\ \text { ADV } & \text { Acoustic Doppler velocity } \\ \text { AMO } & \text { Atlantic Multidecadal Oscillation } \\ \text { CMB } & \text { Conductivity mass balance } \\ \text { NWIS } & \text { National Water Information System } \\ \text { ROMP } & \text { Regional Observation and Monitoring Program } \\ \text { SWFWMD } & \text { Southwest Florida Water Management District } \\ \text { USGS } & \text { U.S. Geological Survey }\end{array}$

Temperature in degrees Fahrenheit $\left({ }^{\circ} \mathrm{F}\right)$ may be converted to degrees Celsius $\left({ }^{\circ} \mathrm{C}\right)$ as follows:

${ }^{\circ} \mathrm{C}=\left({ }^{\circ} \mathrm{F}-32\right) / 1.8$

Vertical coordinate information is referenced to the National Geodetic Vertical Datum of 1929 (NGVD 29).

Altitude, as used in this report, refers to distance above the vertical datum.

Specific conductance is given in microsiemens per centimeter at 25 degrees Celsius $\left(\mu \mathrm{S} / \mathrm{cm}\right.$ at $\left.25^{\circ} \mathrm{C}\right)$.

Concentrations of chemical constituents in water are given either in milligrams per liter (mg/L) or micrograms per liter $(\mu \mathrm{g} / \mathrm{L})$. 



\title{
Surface-Water and Groundwater Interactions along the Withlacoochee River, West-Central Florida
}

\author{
By J.T. Trommer, D.K. Yobbi, and W.S. McBride
}

\section{Abstract}

A study of the Withlacoochee River watershed in westcentral Florida was conducted from October 2003 to March 2007 to gain a better understanding of the hydrology and surface-water and groundwater interactions along the river. The Withlacoochee River originates in the Green Swamp area in north-central Polk County and flows northerly through seven counties, emptying into the Gulf of Mexico. This study includes only the part of the watershed located between the headwaters in the Green Swamp and the U.S. Geological Survey gaging station near Holder, Florida. The Withlacoochee River within the study area is about 108 miles long and drains about 1,820 square miles.

The Withlacoochee River watershed is underlain by thick sequences of carbonate rock that are covered by thin surficial deposits of unconsolidated sand and sandy clay. The clay layer is breached in many places because of the karst nature of the underlying limestone, and the degree of confinement between the Upper Floridan aquifer and the surficial aquifer is highly variable throughout the watershed.

The potential for movement of water from the surface or shallow deposits to deeper deposits, or from deeper deposits to the shallow deposits, exists throughout the Withlacoochee River watershed. Water levels were higher in deeper Upper Floridan aquifer wells than in shallow Upper Floridan aquifer wells or surficial aquifer wells at 11 of 19 paired or nested well sites, indicating potential for discharge to the surfacewater system. Water levels were higher in shallow Upper Floridan aquifer or surficial aquifer wells than in deeper Upper Floridan aquifer wells at five other sites, indicating potential for recharge to the deeper Upper Floridan aquifer. Water levels in the surficial aquifer and Upper Floridan aquifer wells at the remaining three sites were virtually the same, indicating little or no confinement at the sites.

Potentiometric-surface maps of the Upper Floridan aquifer indicate the pattern of groundwater flow in the aquifer did not vary greatly from season to season during the study.

Potentiometric contours indicate groundwater discharge to the river in the vicinity of Dade City and Lake Panasoffkee.
During dry periods, groundwater from the underlying Upper Floridan aquifer contributed to the flow in the river. During wet periods, streamflow had additional contributions from runoff and input from tributaries. Groundwater has a greater effect on streamflow downstream from the Dade City station than upstream from the Dade City station because confinement between surficial deposits and the Upper Floridan aquifer is greater in the Green Swamp area than in downstream areas.

Estimates of streamflow gains and losses were made along the Withlacoochee River during base-flow conditions in May 2004, April 2005, and April 2006. Base flow was higher in April 2005 than in May 2004 and April 2006. Consistent net seepage gains were identified in 16 of 20 subreaches analyzed during all seepage runs. The direction of exchange was variable in the remaining four subreaches.

Low specific conductance, $\mathrm{pH}$, and calcium concentrations in water from the Withlacoochee River near the headwater area indicated a surface-water system not directly connected to the Upper Floridan aquifer. Downstream from the Dade City station, higher specific conductance, $\mathrm{pH}$, and calcium concentrations in the river water indicated an increasing influence of groundwater, and were similar to groundwater during low-flow conditions. Strontium isotope ratios indicate groundwater originates from shallow parts of the Upper Floridan aquifer in the upper reaches of the river, and from increasingly deeper parts of the aquifer in the downstream direction.

Mean annual base-flow estimates also indicate increasing groundwater discharge to the river in the downstream direction. Mean annual base flow estimated using standard hydrograph separation method assumptions ranged from about 4.7 to 5.1 inches per year, or about 76 to 92 percent of total flow. However, the standard assumptions tend to overestimate base flow because of low topographic relief and extensive wetlands located in the watershed. When the hydrograph separation method was calibrated to the local setting using a conductivity mass-balance procedure, mean annual base flow estimates ranged from 0.6 to 2.7 inches per year, or from 1.04 to 47.5 percent of total flow. 


\section{Introduction}

The Withlacoochee River originates in the Green Swamp area in north-central Polk County and flows northerly through seven counties for about $157 \mathrm{mi}$, emptying into the Gulf of Mexico near Yankeetown, Florida (fig. 1). The river drains about $2,100 \mathrm{mi}^{2}$ and is one of only two rivers in the State that flow from south to north. In 1989, the Withlacoochee River was designated an "Outstanding Florida Water" by the Florida Department of Environmental Protection (Southwest Florida Water Management District, 2001a). The Withlacoochee River is a valuable resource to the State of Florida and plays a central role in the hydrology and ecology of west-central Florida. Continuing growth and related water-quality issues could pose future environmental challenges within the watershed. Water managers and local residents have expressed strong concern that increases in water demand may create hydrologic problems similar to those experienced in many other areas of the State, especially the highly developed Tampa Bay area (fig. 1).

Water managers are required to set minimum flows and levels for water bodies throughout the State, including the Withlacoochee River. "Minimum flows and levels" are flows or levels below which significant harm occurs to the water resources or ecology of the area (Southwest Florida Water Management District, 2001a). Increasing competition for groundwater resources and a legislative requirement to set minimum flows and levels for the Withlacoochee River by 2009 have driven State agencies to improve the understanding of the connection between surface water and groundwater. In the northern part of west-central Florida, where many of the rivers are spring fed, an understanding of the extent and magnitude of interaction between the river and the underlying aquifer system will aid water-resources management by documenting current conditions and providing information needed to evaluate the sustainability of the water resources in this relatively undeveloped watershed. This information is essential for addressing issues of water quality and supply, and for ensuring the health of ecosystems. In 2003, the U.S. Geological Survey (USGS) began a cooperative investigation with the Southwest Florida Water Management District (SWFWMD) to gain a better understanding of the hydrology and surface-water and groundwater interaction along the Withlacoochee River. Results from this study can be useful in future decisions affecting the watershed. Studies that include surface-water and groundwater interaction, water-supply watersheds, and source-water protection information are a high priority of the USGS Federal Water Cooperative Program, and the investigative methods of this study have transfer value to other watersheds located in karst areas.

\section{Purpose and Scope}

This report describes the hydrology of the watershed and the interaction of surface and groundwater along the Withlacoochee River. Hydrologic and geologic data collected in the watershed during the 3.5-year study period
(October 2003 - March 2007), historical data from the files of the USGS and the SWFWMD, and data from previously published reports were examined and analyzed. Data were collected at 12 continuous streamflow monitoring stations during the study. Detailed potentiometric-surface maps were constructed and synoptic streamflow measurements were made to assess the interconnection between the river and groundwater system. Areas of hydraulic connection between the river and aquifers were identified. Surface-water and groundwater quality data were compared to assess sources and interconnection between the hydrologic systems. Annual data included in this report are presented by water year (a 12-month period from October 1 through September 30). All continuously recorded streamflow as well as water-quality data are stored in the USGS National Water Information System (NWIS) databases.

\section{Previous Studies}

The Withlacoochee River watershed is included in geologic and geomorphic studies conducted by Cooke (1939, 1945), Vernon (1951), White $(1958,1970)$, Yon and Hendry (1972), and Scott (1988). Pride and others $(1961,1966)$ described the hydrologic features of the Green Swamp area. Rabon (1967) described the inflow and outflow characteristics of Lake Rousseau (Inglis Reservoir) on the Withlacoochee River. Cherry and others (1970) described the hydrogeology of the middle gulf area of Florida, which includes part of the Withlacoochee River watershed. Grubb (1977) studied the potential for downward leakage to the Floridan aquifer system in the Green Swamp area. Taylor (1977) described the hydrology of Lake Panasoffkee, and Rutledge (1977) and Bradner (1988) described the water resources of Tsala Apopka Chainof-Lakes in Citrus County. Both lakes are within the Withlacoochee River watershed. Lake Panasoffkee discharges to the river. Tsala Apopka Chain-of-Lakes at times receives river inflow and at other times discharges to the river. German (1978) described the hydrology of Lake Rousseau. Grubb and Rutledge (1978) evaluated the long-term water-supply potential of the Green Swamp area. Anderson (1980) described the hydrology of Jumper Creek Canal, a tributary to the Withlacoochee River in Sumter County. Miller and others (1981), Anderson and Laughlin (1982), and Kimrey and Anderson (1987) described the water resources of the Withlacoochee River region. Anderson and Laughlin (1982) described the geohydrology of the Floridan aquifer system in the Withlacoochee River basin. Camp and Barcelo (1988) investigated surface-water and groundwater interactions near the Wysong Dam and Lake Panasoffkee. In 2001, the SWFWMD developed a comprehensive watershed plan and Atlas for the Withlacoochee River watershed. The USGS has published potentiometric-surface maps of the Upper Floridan aquifer, which include the Withlacoochee River watershed, intermittently from 1934 to January 1964, every other year from May 1969 to May 1973, annually from May 1973 to May 1975, and in May and September of every year beginning in May 1975 to the present. 


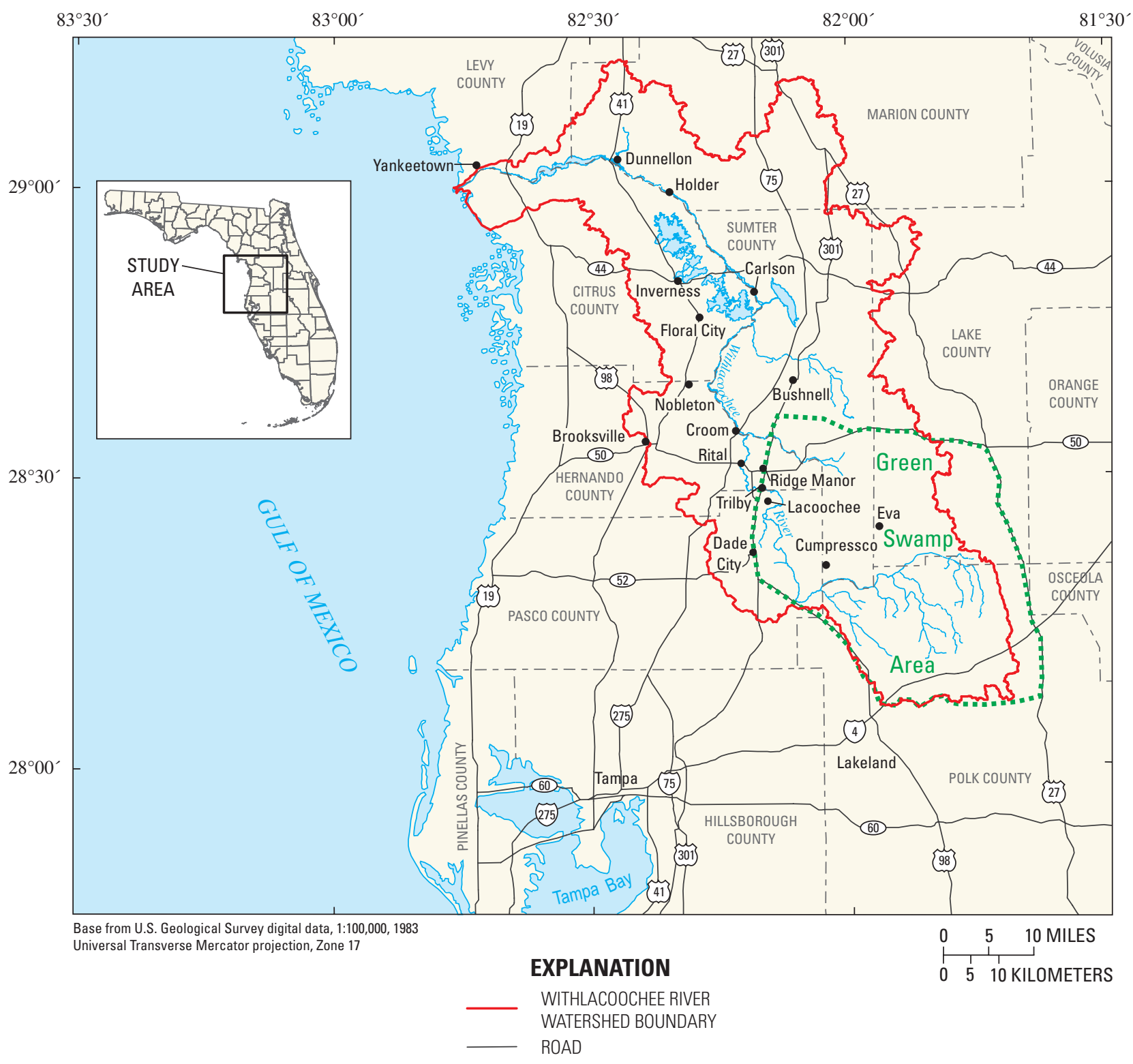

Figure 1. Location of the Withlacoochee River watershed, west-central Florida. 
Surface-Water and Groundwater Interactions along the Withlacoochee River, West-Central Florida

\section{Description of Study Area}

The study concentrates on the Withlacoochee River from the discontinued USGS gaging station near Eva, in the Green Swamp area (site SW1, fig. 2 and table 1), to the USGS gaging station near Holder (site SW13, fig. 2 and table 1). The Holder station was chosen as the end of the study area because it is the farthest downstream gage where streamflow is not affected by impounded or structurally altered water levels from Lake Rousseau. The Withlacoochee River within the study area is about $108 \mathrm{mi}$ long and drains about $1,820 \mathrm{mi}^{2}$. The river stage drops from an altitude of about $105 \mathrm{ft}$ above NGVD 29 at the Eva station, to about $25 \mathrm{ft}$ above NGVD 29 at the Holder station. The river has an average fall of $1.5 \mathrm{ft} / \mathrm{mi}$ from the Green Swamp area to the town of Lacoochee (fig. 1). Between Lacoochee and the Holder station, the gradient is only about $0.3 \mathrm{ft} / \mathrm{mi}$ (White, 1958). The main tributaries to the river are Pony Creek, Grass Creek, Gator Hole Slough, Little Withlacoochee River, Jumper Creek, Outlet River, and Gum Slough (fig. 2). The largest open surface-water bodies in the study area are Lake Panasoffkee and the interconnected lakes and wetlands that form the Tsala Apopka Chain-of-Lakes. Inflow to Lake Panasoffkee is from springs along Shady Brook, Big Jones Creek, and Little Jones Creek (fig. 2). Outflow from Lake Panasoffkee to the Withlacoochee River is through the Outlet River (Southwest Florida Water Management District, 1994). Within the study area, several springs flow into the Withlacoochee River, including Dobes Hole Spring, Riverdale Spring, Nichols Spring, Gum Slough Springs, Wilson Head Spring and Blue Spring (fig. 2).

Drainage in the area around the Tsala Apopka Chainof-Lakes and the Withlacoochee River has been extensively modified. Water-level control structures allow water to flow from the Withlacoochee River to the lake from the south, and to the river from the lake to the north. Natural flow from the Withlacoochee River to the lake can occur when water overflows the banks of the river during high flow events (Southwest Florida Water Management District, 1994). In addition, an inflatable fabric dam, known as the Wysong Dam, was placed across the river about $2 \mathrm{mi}$ downstream from the mouth of the Outlet River (fig. 2). All these structures are operated to prevent extreme low water levels and conserve water in Lake Panasoffkee, the Tsala Apopka Chain-of-Lakes, and the Withlacoochee River upstream from the Wysong Dam.

Land-surface altitudes in the Withlacoochee River watershed range from about $40 \mathrm{ft}$ to greater than $300 \mathrm{ft}$ above NGVD 29. The Withlacoochee River originates in the Lake Uplands physiographic province and flows through the Western Valley, Brooksville Ridge, and Tsala Apopka Plain (fig. 3). Sections of the Brooksville Ridge, Ocala Hill, Cotton Plant Ridge, Lake and Sumter Uplands, Lakeland Ridge, and Winter Haven Ridge physiographic provinces described by White (1970) are located in the watershed (fig. 3). The most prominent ridge in the watershed is the north-trending Brooksville Ridge. The Brooksville Ridge is the westernmost and largest of the central Florida ridges. Land-surface altitudes along the ridge range from 70 to just over $300 \mathrm{ft}$ above NGVD 29 (Southwest Florida Water Management District, 2001a). The topography is hilly because of karst features (Vernon, 1951), with land-surface altitudes varying greatly over short distances. Depressional features and sinkholes are common. The Withlacoochee River flows north and west to the Gulf of Mexico through the Dunnellon Gap, an erosional feature that splits the Brooksville Ridge. This gap is responsible for reversing the ancient course of the river from south to north (White, 1958), and lowering water levels in the Tsala Apopka Chain-of-Lakes to present day levels (White, 1970). Lowland physiographic provinces that make up parts of the watershed include the Tsala Apopka Plain and the Western Valley (fig. 3). The flat, low-lying Tsala Apopka Plain is part of the Western Valley and parallels the Brooksville Ridge in the central part of the watershed. The Tsala Apopka Plain is an erosional valley with land-surface altitudes ranging from about 40 to $75 \mathrm{ft}$ above NGVD 29. Lake Panasoffkee, the Tsala Apopka Chain-of-Lakes, and the Withlacoochee River are located in the lower lying areas of the plain. The Western Valley is located east of the Tsala Apopka Plain, with land-surface altitudes ranging from about 40 to $100 \mathrm{ft}$ above NGVD 29. In the northern part of the watershed, the Western Valley lies between the Brooksville Ridge, Cotton Plant Ridge, and Sumter Upland. In the southern part of the watershed, the Western Valley separates the Tsala Apopka Plain from the Lake Upland.

The karst nature of the landscape in the watershed is due to irregular weathering of the limestone surface, illustrated by small-localized sinkholes, sinkhole lakes (primarily on the ridges), isolated circular wetlands, and coalescence of multiple sinkholes in wetlands and lakes.

The study area is predominately rural, and contains substantial public land. Although residential and commercial development in the area is increasing, the watershed remains largely undeveloped. Only about 12 percent of the watershed is developed, primarily as residential housing (Tetra Tech, Inc., 2004). The watershed includes ecosystems ranging from forested river floodplain, cypress domes, pine flatwoods, and sandhills in the Green Swamp, to extensive lake systems and marshes in the middle watershed, to salt marshes and an estuary at the mouth of the river (Florida Department of Environmental Protection, 2005). Agricultural land use is primarily improved pasture, and lime rock mining is the largest industrial land use in the watershed. Major towns include Brooksville, Bushnell, Dade City, Dunnellon, Inverness, and Ridge Manor (fig. 1). Currently, no urban centers are located along the Withlacoochee River.

The study area has a subtropical climate with warm, humid summers and mild, dry winters. Average temperature in the watershed is about $72^{\circ} \mathrm{F}$; however, temperatures often reach $95^{\circ} \mathrm{F}$ in the summer and can drop below freezing in the winter when cold fronts move through the area. Rainfall varies seasonally, with about 60 percent occurring between June and September from intense localized thunderstorms as well as occasional tropical storms. Winter frontal storms account for most of the rainfall from December through March. Mean annual rainfall is about 55 in. for the watershed (Southwest Florida Water Management District, 2001a). 


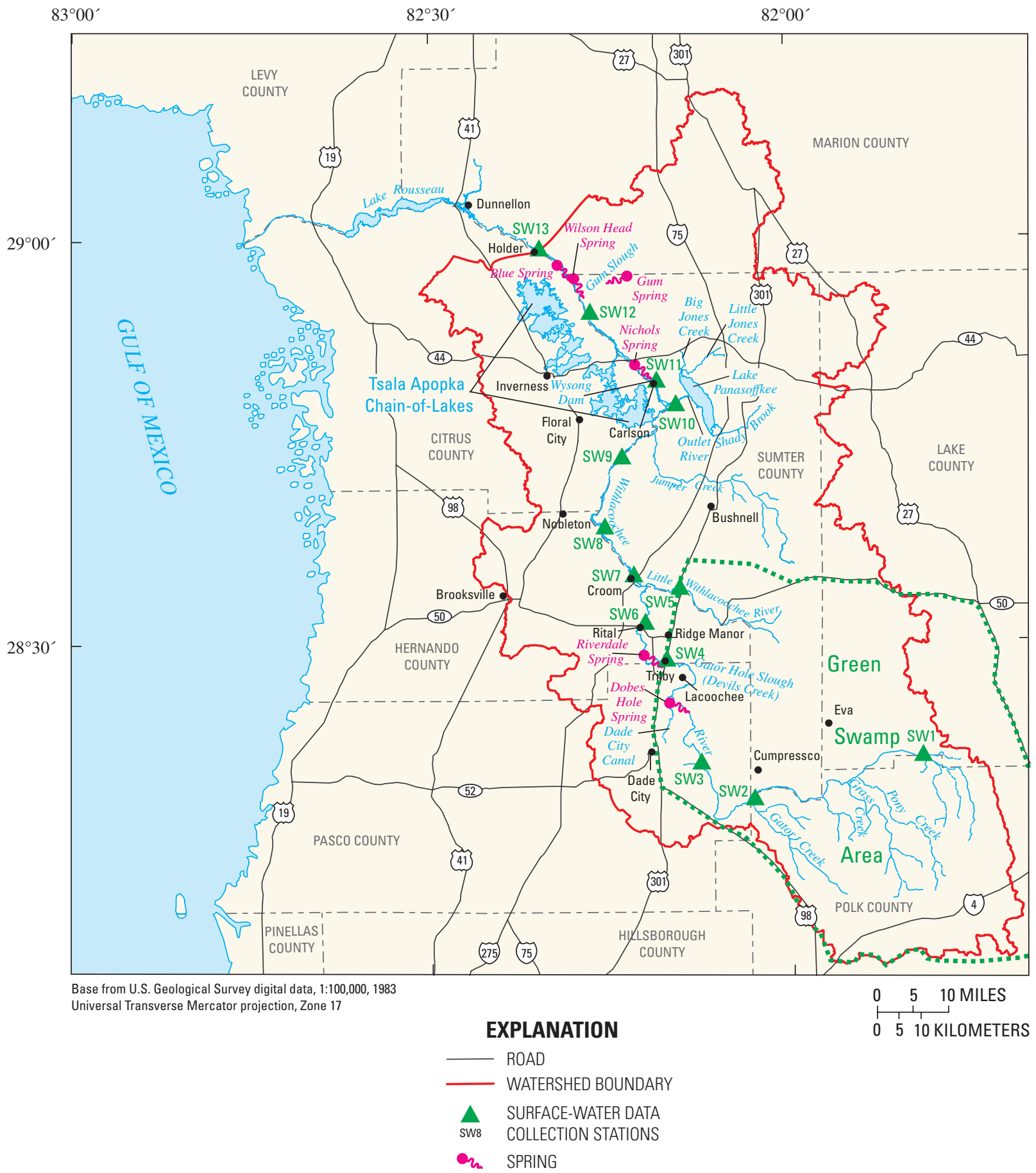

Figure 2. Location of the study area and the surface-water data collection network. Site identification numbers and names are given in table 1 . 
Table 1. Surface-water data collection sites.

[Period of record is a water year covering a 12-month period from October 1 to September 30. Miscellaneous water-quality samples collected and streamflow measurements made at site SW1. Continuous daily discharge stations are sites SW2 to SW13]

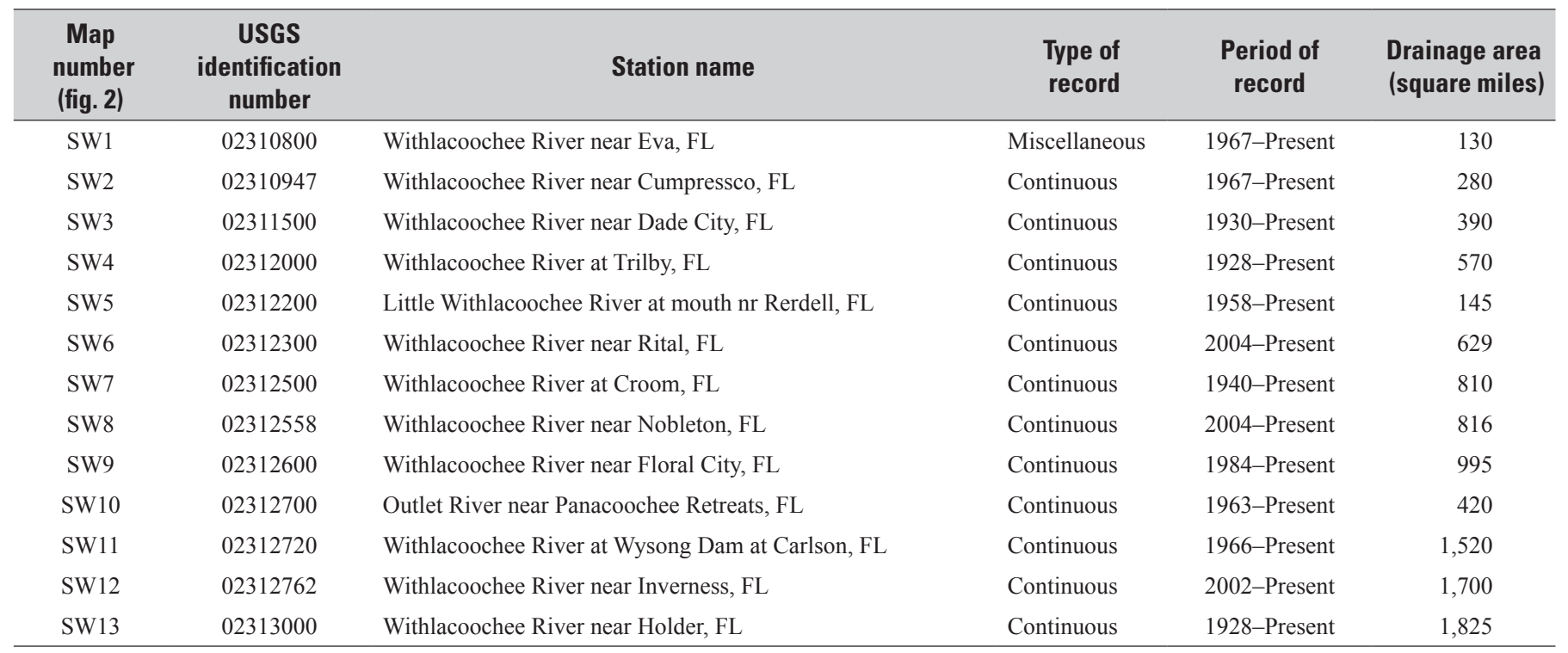

\section{Methods}

Major components of data collection for the study included streamflow and groundwater level measurements, well installation, a seismic reflection survey, and surface-water and groundwater sampling for water quality. Synoptic streamflow measurements during low-flow conditions were conducted to calculate surface-water and groundwater exchanges between the river and aquifer.

Groundwater data from 291 wells completed into the Upper Floridan aquifer were used to map the potentiometric surface of the aquifer for dry (May) and wet (September) season conditions for this study. A total of 221 of these wells are part of a larger regional network used to produce semi-annual potentiometric-surface maps. An additional 70 wells were used in the study. These include local area wells, and the deep and shallow nested wells drilled during this study. All wells and reference points were leveled to NGVD 29. Spatial and temporal patterns of recharge and discharge were evaluated by comparing water levels in shallow and deep Upper Floridan aquifer wells and surficial aquifer wells where possible. Paired surficial aquifer and Upper Floridan aquifer wells or shallow and deep Upper Floridan aquifer wells were installed at five sites during this study to compare water levels and evaluate the potential for recharge or discharge along the river. Eight additional existing well clusters also were used to evaluate groundwater movement.

Thirteen continuous streamflow stations were operated by the USGS in the Withlacoochee River watershed during the study period. The northernmost station located near Dunnellon (fig. 1) was not used for analysis because of backwater conditions from Lake Rousseau, thus 12 stations were used for analysis. The discontinued (1993) USGS streamflow station at Eva (site SW1, fig. 2 and table 1) was added as a miscellaneous streamflow and water-quality station for this study because of its location in the upstream headwater area in the Green Swamp (fig. 2). Ten surface-water stations were established prior to the study and thus have historical data. The stations near Rital, Nobleton, and Inverness (sites SW6, SW8, and SW12, table 1 and fig. 2) were established for this study.

In March 2004, the USGS conducted a geophysical seismic-reflection survey along the Withlacoochee River to identify seismic reflectors that could be correlated to hydrogeologic units and karst features. The river was profiled between Dunnellon and Rital (fig. 4). A boomer (transducer) was towed on a sled at the water surface that when discharged emitted a short acoustic pulse, or shot, that propagated through the water and sediment column. The acoustic energy was reflected at density boundaries (such as the riverbed or sediment layers beneath the riverbed), detected by the receiver, and recorded by a PC-based seismic acquisition system. Twodimensional vertical images of the shallow geologic structure beneath the ship track were produced and included in a data report that was published in 2006 (Calderon and others, 2006).

Synoptic streamflow measurements (seepage runs) were made along the Withlacoochee River during differing lowflow conditions over 3- to 4-day periods to quantify streamflow gains or losses, and to evaluate areas of measurable interaction between the surface-water system and underlying aquifer. The USGS daily discharge station near Holder (site SW13) was the farthest downstream site included in the seepage runs because it represented the approximate end of natural channel conditions not influenced by the structurally controlled water levels of Lake Rousseau. The river was 


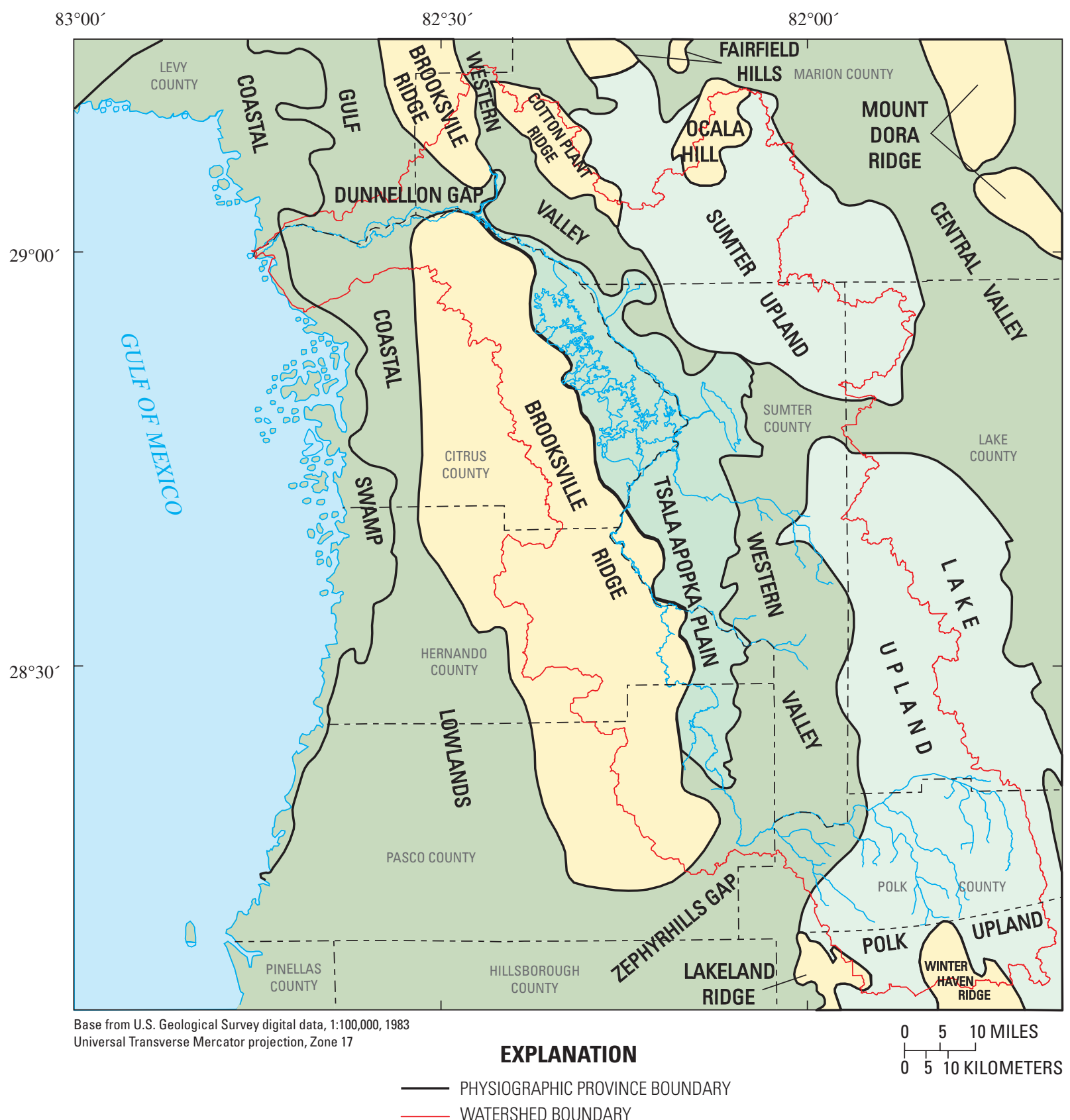

Figure 3. Physiography of the study area (modified from White, 1970). 


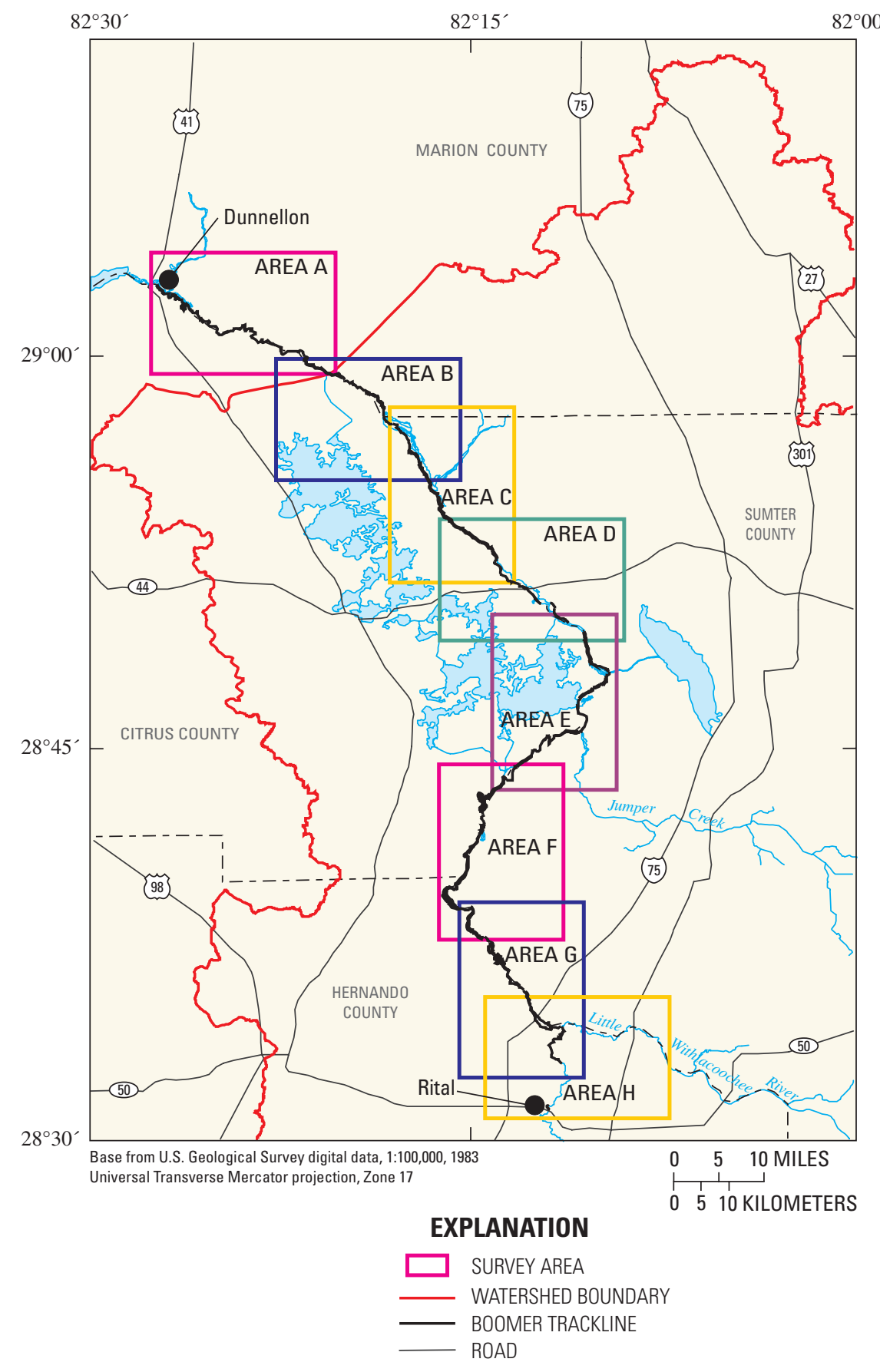

Figure 4. Location of seismic-reflection survey areas along the Withlacoochee River (modified from Calderon and others, 2006).

divided into 4 main reaches and 20 subreaches between measurement sites. Successive downstream measurements were compared to determine if river segments were gaining water from or losing water to the groundwater system. An increase in streamflow at the downstream point in a river reach not accounted for by tributary inflow or spring flow was attributed to groundwater seepage into the river. Likewise, a decrease in streamflow at the downstream location was attributed to recharge to the groundwater system from the river. Sources of discharge data included records of streamflow at USGS gages, acoustic Doppler velocimeter (ADV) measurements, and acoustic Doppler current profiler (ADCP) measurements. Streamflow at each location was measured directly or determined from a rating curve at a streamflow gaging station. Standard USGS methods, as described in Rantz and others (1982) and Oberg and others (2005), were used to make measurements and compute streamflow. In this report, a threshold of 5 percent of the average of the upstream and downstream 
discharge values was used to identify apparent net seepage gains or losses. Additionally, when streamflow is low, small differences in the measurements may produce large percentage differences. To compensate for this, the average streamflow of the upstream and downstream sites had to exceed $0.5 \mathrm{ft}^{3} / \mathrm{s}$ before the greater than 5-percent net seepage gain or loss would be considered significant.

Samples for water-quality analysis were collected from seven surface-water sites, two springs, and three Upper Floridan aquifer wells. All water-quality samples were collected using methods described in the USGS National Field Manual for the Collection of Water-Quality Data (U.S. Geological Survey, variously dated). Specific conductance, temperature, $\mathrm{pH}$, and dissolved oxygen were measured in the field. Samples were analyzed for dissolved major ions and trace metals, organic carbon, and the stable isotopes of strontium $\left({ }^{87} \mathrm{Sr} /{ }^{86} \mathrm{Sr}\right)$. Strontium isotope ratios $\left({ }^{87} \mathrm{Sr} /{ }^{86} \mathrm{Sr}\right)$ in surface-water samples were compared to ratios from groundwater samples to gain insight about the source of the water in the streams (DePaolo and Ingram, 1985; Hess and others, 1986; Howarth and McArthur, 1997).

Hydrograph separation techniques were used to estimate the groundwater contribution to streamflow (base flow) at long-term streamflow stations. Within the Withlacoochee River watershed, hydrograph separation methods were applied to data from the Cumpressco, Dade City, Croom, and Holder gaging stations (sites SW2, SW3, SW7, and SW13, respectively). A method developed by Stewart and others (2007) to calibrate hydrograph separation methods using streamflow conductivity was used to improve the accuracy of the hydrograph separation base-flow estimates. Base flow was calculated using a conductivity mass-balance (CMB) method that assumes base flow conductivity is equal to streamflow conductivity at the lowest flows, and runoff conductivity is equal to streamflow conductivity at the highest flow. Continuous streamflow and conductivity data collected during the study were used to calculate base flow. The hydrograph separation method was then calibrated to the CMB method by varying the time parameter (Stewart and others, 2007). A spreadsheet based on the USGS HYSEP computer program (Sloto and Crouse, 1996), an analytical "time of cessation of runoff" technique, was used so the time could be varied easily (Stewart and others, 2007). The calibrated hydrograph separation method was then applied to long-term records for four gaging stations. Base flow for the 1983 to 2006 period was calculated because this was the longest overlapping period of record at these stations over which continuous streamflow data were available.

Data from Romp WR6 transect wells constructed and maintained by the SWFWMD were used to evaluate the groundwater component of flow in the river (Mallams, 2007). The well transect is located across the Withlacoochee River near the Croom gaging station (site SW7), and consists of four well clusters, two on each side of the river. Each cluster contains a deep Upper Floridan aquifer well completed into the Avon Park Formation, a shallow Upper Floridan aquifer well completed into the Ocala Formation, and a surficial aquifer well completed into the sandy surficial deposits. The nested wells are designed to monitor head differences with depth.

\section{Groundwater Hydrology}

The watershed contains several large springs and many smaller springs indicative of a karst-dominated groundwater flow system (Florida Department of Environmental Protection, 2005). Sinkholes, caves, and depressional features characteristic of karst are all located within the Withlacoochee River watershed. Karst is terrain with distinctive hydrology and landforms resulting from a combination of high rock solubility and well developed secondary porosity due to solution along structural pathways within the rocks (Ford and Williams, 1989).

\section{Hydrogeologic Framework}

The stratigraphy and hydrogeology of the Withlacoochee River watershed is relatively simple. A veneer of clastic material of variable thickness overlies a thick, near-surface sequence of carbonate rock. The most recent sediments are alluvium and terrace deposits of Holocene and Pleistocene age consisting of quartz sand and clay (fig. 5). Most of these deposits consist of undifferentiated reworked material from the underlying Cypresshead Formation. The Cypresshead Formation of Pliocene age is located at or near land surface east of the Withlacoochee River (fig. 6) and consists of phosphate sands and clays. Underlying the Cypresshead Formation are phosphatic sands, clayey sands, and clays of the Hawthorn Group of early Miocene age. The Hawthorn Group is thin and discontinuous in the south, and generally absent toward the north, except for a few erosional remnants associated with the ridges. The limestone units beneath the clastic deposits of the Cypresshead Formation and the Hawthorn Group in this region can include the Suwannee Limestone of Oligocene age, and Ocala Limestone and Avon Park Formation of Eocene age. The Suwannee Limestone was eroded in most parts of the watershed after the Oligocene age (Miller, 1986) and is absent along the channel of the Withlacoochee River. The Ocala Limestone is permeable, has a highly irregular karstified surface, and is present at or near the surface along most of the Withlacoochee River channel (fig. 6). Underlying the Ocala Limestone is the Avon Park Formation. The Avon Park Formation is the deepest formation in this area that contains potable water. The lower part of the formation contains extensive evaporite deposits that form an impermeable unit that separates the upper potable zone from the lower non-potable zone. In northern Sumter and southern Marion Counties, the evaporite deposits are absent and a largely carbonate zone of lower permeability separates the upper and lower zones (Miller, 1986). Detailed information about the geology of the area can be found in Puri and Vernon (1959) and Stringfield (1966).

The principal hydrogeologic units within the watershed are the surficial aquifer located within the sandy alluvium terrace deposits, the intermediate confining unit located within Hawthorn Group clays, the Upper Floridan aquifer located within the Suwannee and Ocala Limestones and the upper 


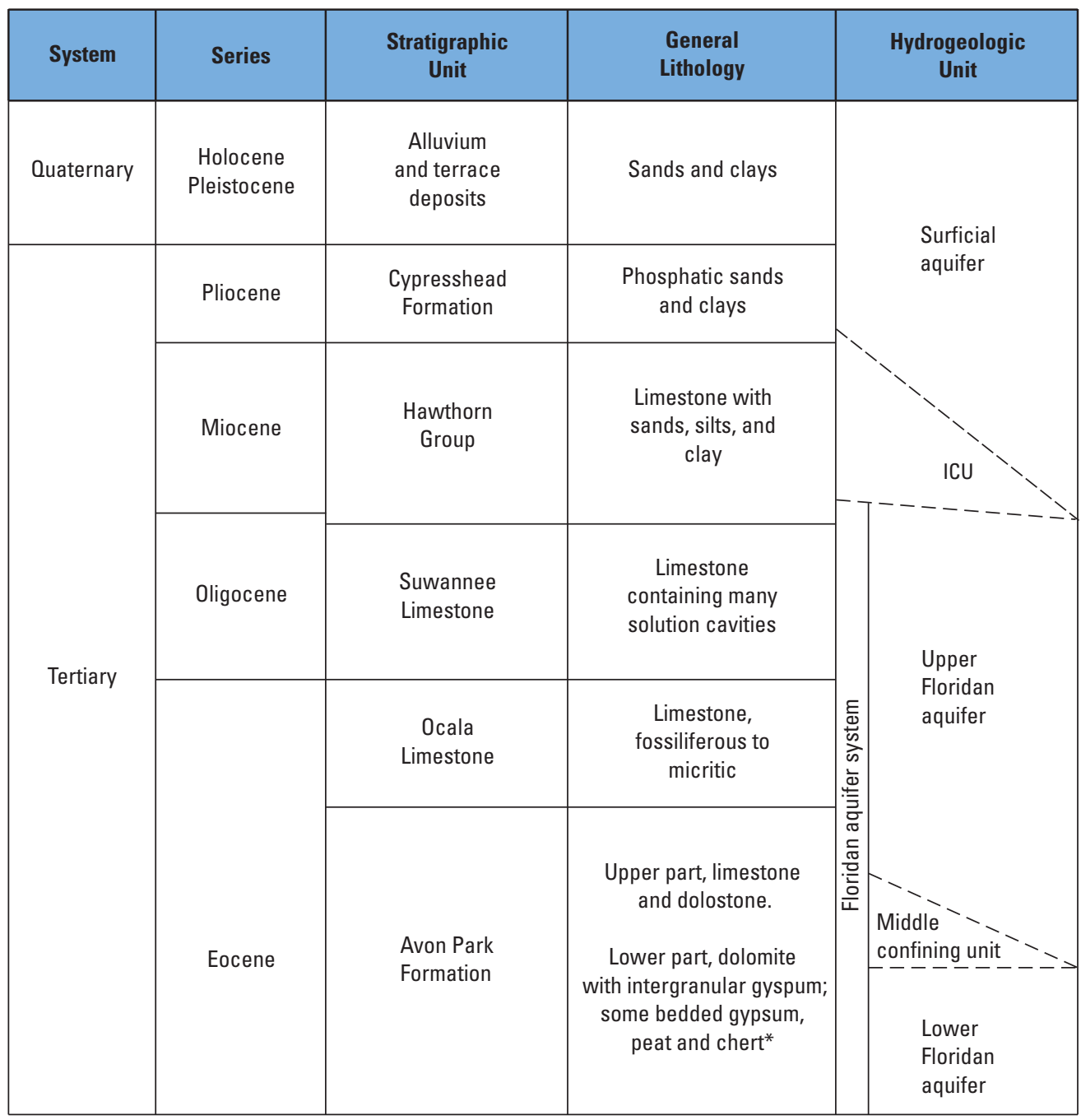

*Except in northeastern part of the watershed where formation is mostly carbonate.

Figure 5. Generalized hydrostratigraphy for the study area (modified from Sacks, 1996).

ICU (intermediate confining unit) is of limited areal extent in the study area.

Avon Park Formation, the middle confining unit located in the lower evaporate deposits of the Avon Park Formation, and the Lower Floridan aquifer located in the underlying carbonate rocks (fig. 5). The intermediate confining unit separates the surficial aquifer from the Upper Floridan aquifer and is discontinuous throughout the Withlacoochee River watershed. The middle confining unit separates the Upper Floridan aquifer from the Lower Floridan aquifer (Miller, 1986).

The surficial aquifer in the watershed consists of unconsolidated clastic sediments of sand, clayey sand, and organic debris. This unit is referred to as the surficial aquifer system where more than one permeable unit is present, or where these units are interbedded (Metz and Sacks, 2002). In this area, these deposits form a single water-bearing zone referred to as the surficial aquifer, rather than a system. The thickness of the aquifer is variable; generally, surficial deposits are thinnest near the river and thickest toward the ridges. A continuous surficial aquifer does not extend across the entire study area because of the variability of the underlying confining unit. Where low permeability clays of the Hawthorn Group (Scott, 1988) separate the limestone and sand, a water table may develop within the sands. In the eastern part of the Green Swamp area, the surficial aquifer can be 50 to $100 \mathrm{ft}$ thick, whereas in the western part it can be 0 to $50 \mathrm{ft}$ thick. Where these deposits directly overlie limestone, a surficial aquifer is not present. Along the Withlacoochee River, the surficial aquifer is generally thin to nonexistent, and the Upper Floridan aquifer is exposed along much of the river channel. 


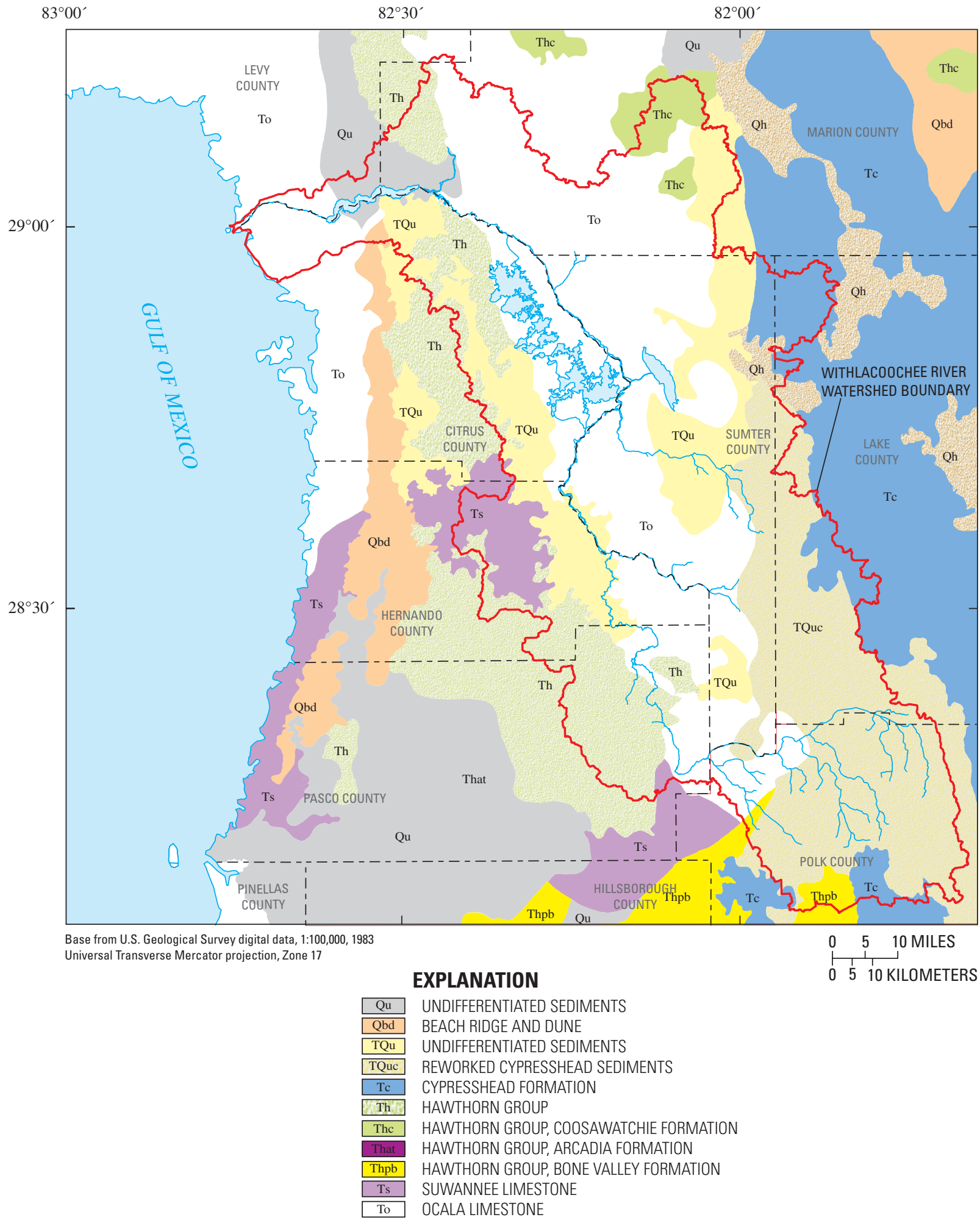

Figure 6. Geology at or near land surface, west-central Florida (modified from Scott and others, 2001). 
Within the surficial aquifer, the occurrence of a water table is influenced by seasonal rainfall and the continuity of the underlying confining unit. When present, the water table in the surficial aquifer ranges from land surface near ponds and wetland areas to greater than $15 \mathrm{ft}$ below land surface along the ridges (Southwest Florida Water Management District, 1994). The surficial aquifer is not a substantial source of water supply in the Withlacoochee River watershed. However, where present, the surficial aquifer does provide a source of water that flows to streams, and recharges the Upper Floridan aquifer either by downward vertical leakage through the confining unit, or directly through breaches in the confining unit.

The intermediate confining unit underlies the surficial aquifer and consists of siliclastic sediments of Miocene age that include interbedded sand, clay, limestone, sandy phosphatic limestone, and marl (Anderson and Laughlin, 1982). The confining unit is thin and discontinuous toward the north and along the stream channels, except for a few erosional remnants associated with the ridges. Where present, the confining unit ranges in thickness from a few feet to more than $50 \mathrm{ft}$ and is commonly breached by karst features (Southwest Florida Water Management District, 2001a).

The Upper Floridan aquifer underlies the intermediate confining unit. In parts of the watershed where an intermediate confining unit is present, the aquifer is semiconfined because of the karst nature of the terrain. The Upper Floridan aquifer is a regional aquifer consisting of multiple layers of continuous limestone and dolomite that include the Suwannee Limestone, Ocala Limestone, and Avon Park Formation. The Suwannee Limestone is absent throughout most of the watershed, except in the Brooksville and Lakeland Ridge areas. The Upper Floridan aquifer is at or near land surface along the Withlacoochee River and the river channel has been eroded into the rock surface of the Ocala Limestone (fig. 6). The karst nature of the Ocala Limestone provides an opportunity for direct hydraulic and geochemical interactions between the surface-water and groundwater systems. Evaporites of gypsum and anhydrites infill the pore spaces in the lower part of the Avon Park Formation, forming the lower boundary of the aquifer, and are referred to as the middle confining unit (Miller, 1986). The middle confining unit underlies most of the watershed. In the northeastern part of the watershed, the evaporites pinch out and a layer of low permeable carbonate rock separates the Upper and Lower Floridan aquifers (fig. 5).

The Lower Floridan aquifer contains non-potable water throughout most of the watershed. Although generally not used as a source of water, in the extreme northeastern part of the watershed, the water in this aquifer is fresh, and some wells are completed into the Lower Floridan aquifer.

\section{Groundwater Levels}

Vertical water-level differences between shallow and deep Upper Floridan aquifer wells and surficial aquifer wells (where a water table was present) were used to evaluate the recharge and discharge potential and degree of confinement at
19 sites with paired or nested wells (fig. 7 and table 2). Water levels in the deeper Upper Floridan aquifer wells were higher than in the shallow Upper Floridan aquifer wells or surficial aquifer wells at 11 sites (GW1, GW2, GW3, GW5, GW10, GW11, GW12, GW15, GW16, GW17, and GW18), indicating upward potential for discharge to the surficial aquifer. Surficial aquifer wells are located at six of these sites (sites GW10, GW11, GW12, GW15, GW16, and GW17). With the exception of site GW11, a water table was present in the surficial aquifer at these sites during all site visits during the study period (October 2003-September 2006). The surficial aquifer well at site GW11 contained water only twice during site visits, in September 2004 and July 2005. At those times, the water table in the surficial aquifer was higher than the potentiometric surface of the Upper Floridan aquifer, resulting in a temporary potential for recharge to the Upper Floridan aquifer. The transient reversal in head gradient also was observed at site GW2 during wet conditions when surficial sediments became saturated. The hydrograph of the Green Swamp medium deep and shallow wells (site GW2) illustrates a water-level reversal during a wet period in March 2005 (fig. 8).

Water levels in the shallow Upper Floridan aquifer or surficial wells were higher than in the deeper Upper Floridan aquifer wells at five sites (sites GW4, GW6, GW9, GW14, and GW19), indicating downward potential for recharge to the Upper Floridan aquifer and possibly lower permeability of the deposits between the shallow and deep wells. Surficial aquifer wells are located at three of these sites (sites GW9, GW14, and GW19). A water table was present in the surficial aquifer at sites GW14 and GW19 during all site visits during the study period. The surficial aquifer well at site GW9 was dry during all site visits.

Water levels in the surficial aquifer and Upper Floridan aquifer wells at site GW13 (fig. 7 and table 2) were virtually the same, indicating little or no confinement at the site, and that the Upper Floridan aquifer is under water-table conditions. Similar conditions were observed at sites GW7 and GW8 for the deep and shallow Upper Floridan aquifer wells; however a water table was not observed in the surficial aquifer well at site GW8 during the study period, and was only observed in the surficial aquifer well at site GW7 during September site visits in 2004 and 2005. At that time, the water table was higher than the potentiometric surface of the Upper Floridan aquifer, indicating a temporary downward potential for recharge to the Upper Floridan aquifer. Similar to sites GW2 and GW11, the surficial aquifer at site GW7 appears to contain water only during wet periods when rainfall is sufficient to saturate surficial deposits.

Cumulative groundwater levels were plotted against time for four long-term well sites. Plots were developed with average annual water-level data for the period between 1964 and 2006. A resulting straight line indicates that data are proportional, and that the slope represents the proportionality of the variables. A change in slope of the resulting line indicates a change in the proportionality of the variables, and the time at which the change occurred (Searcy and Hardison, 1960). 


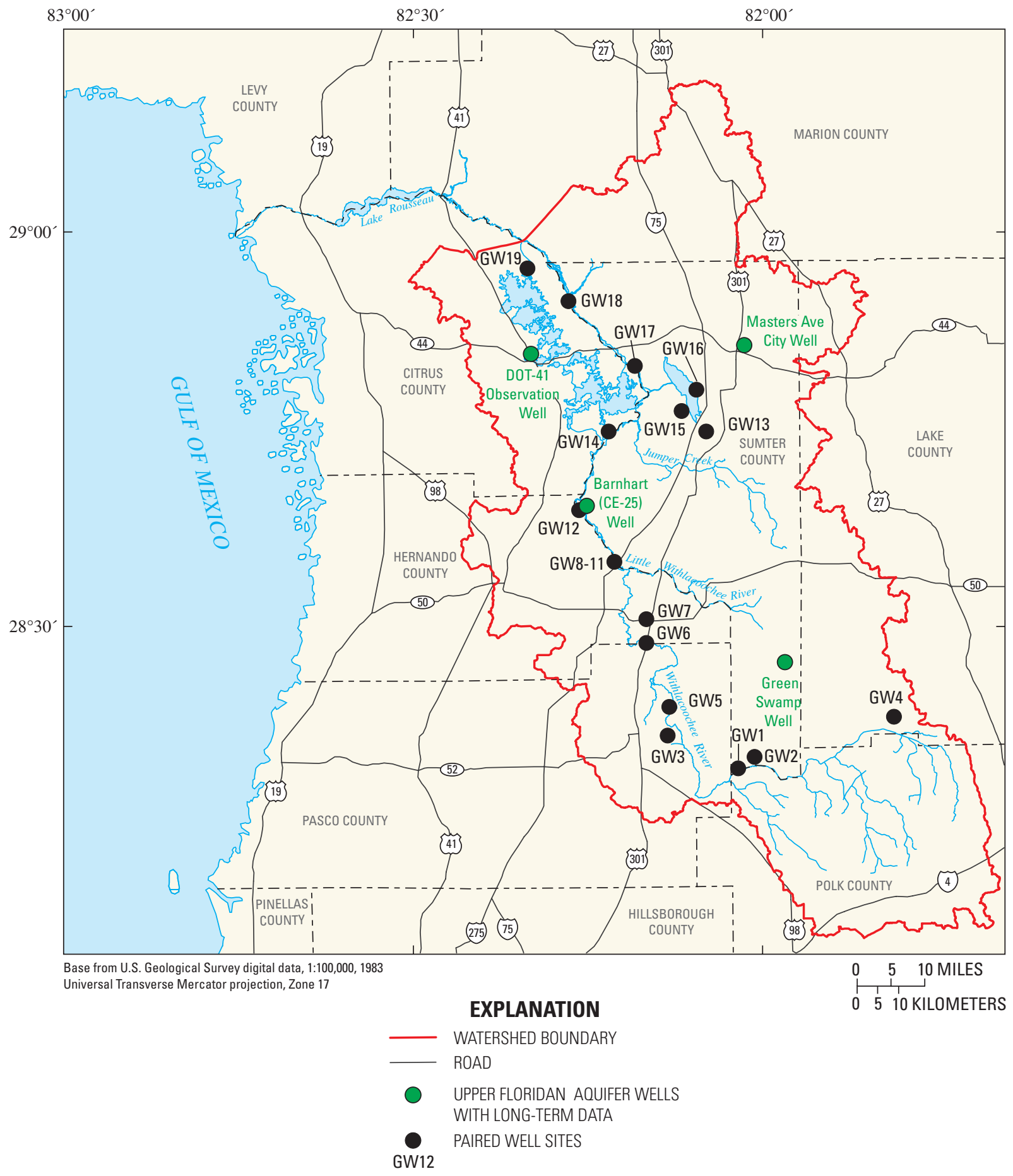

Figure 7. Location of the paired well sites and Upper Floridan aquifer wells with long-term data. Site identification numbers and names of paired well sites are given in table 2 . 
Table 2. Groundwater data collection sites with paired deep and shallow wells.

[UFA, Upper Floridan aquifer: SAS ${ }^{1}$, surficial aquifer system]

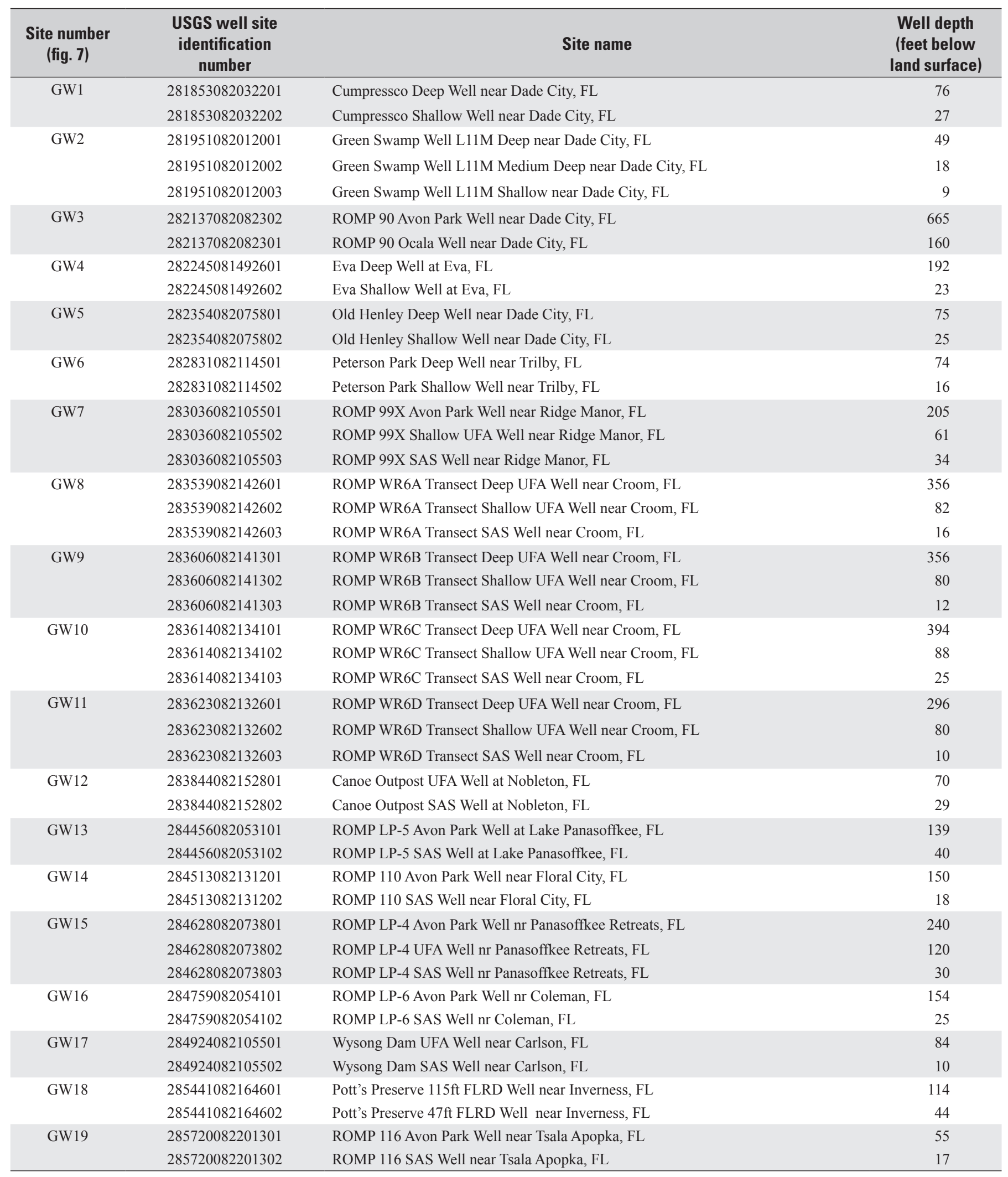

${ }^{1}$ Although many site names include the acronym SAS (surficial aquifer system), the term surficial aquifer is used throughout the rest of this report because the aquifer consists of a single water-bearing zone. 


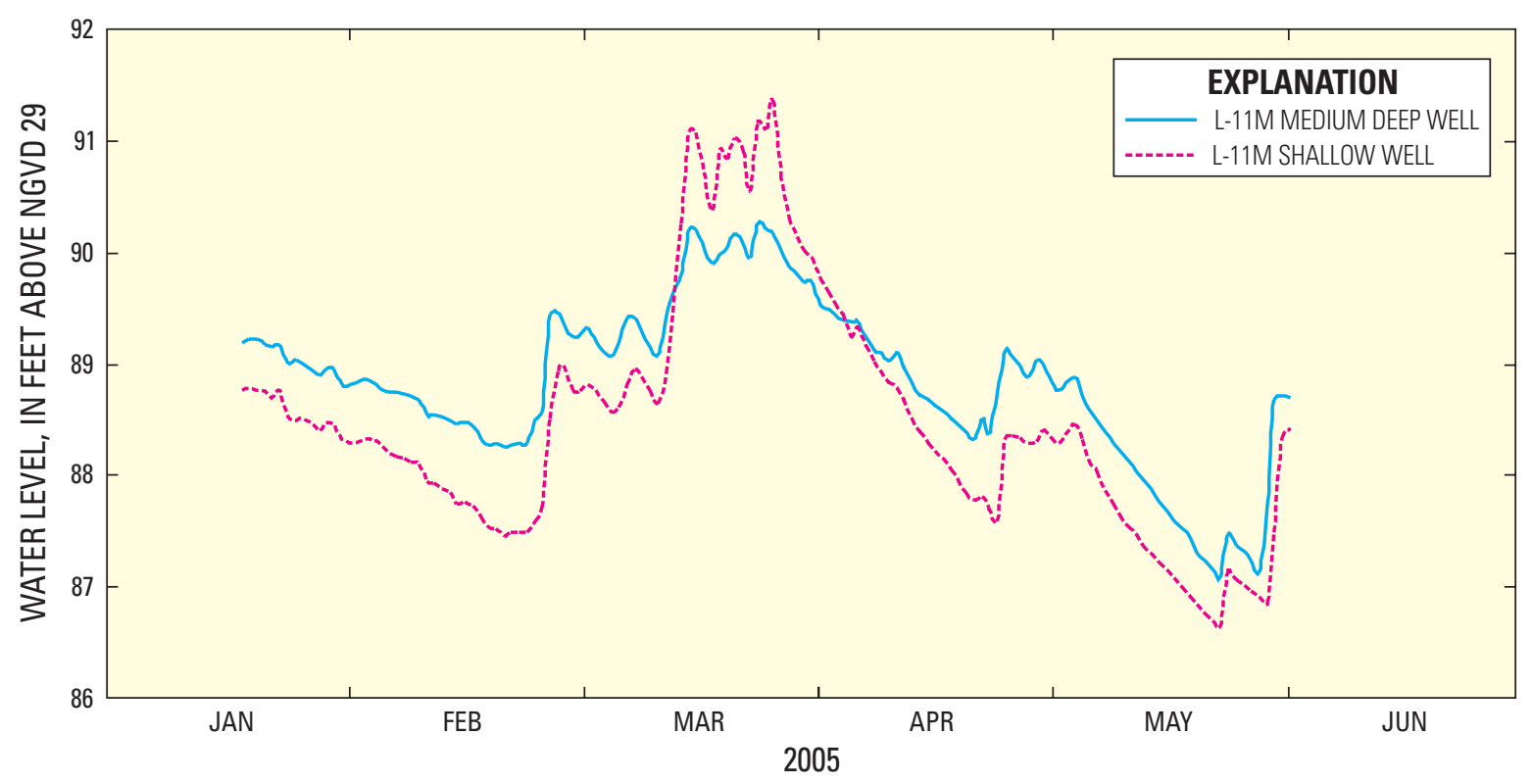

Figure 8. Transient nature of surficial aquifer water levels at the Green Swamp L-11M well site (site GW2 in figure 7 and table 2).

Analysis of cumulative water-level data shows a small change in the slope of the graph for the Green Swamp, Barnhart, and Masters Ave well sites occurring about 1983 (fig. 9). The graphs show a steeper slope after 1983, indicating higher water levels. Analysis of the DOT-41 observation well data did not indicate a similar change in slope. The water level at this well appears to be consistent over the entire period of record (fig. 9). Cumulative groundwater data also were plotted against cumulative rainfall for the four long-term sites. The resulting graphs for the Green Swamp, Barnhart, and Masters Ave wells are similar, also showing a small change in slope occurring about 1983 to a steeper slope. Analysis of cumulative groundwater and rainfall data for the DOT -41 observation well did not show a change in slope around 1983. Analysis of cumulative water-level and rainfall data indicates that rainfall within the Withlacoochee River watershed and groundwater levels are related.

Potentiometric-surface maps of the Upper Floridan aquifer were constructed for the dry season in May and wet season in September during 2004-06 (fig. 10). The September 2005 map (fig. 10A) represents wet-season water levels, and the May 2006 map (fig. 10B) represents dry-season water levels. The map contours were similar for all periods, indicating the pattern of groundwater flow in the aquifer did not vary greatly. Two large potentiometric highs were observed in the watershed during the study period, the largest located in the area of the Green Swamp in the southeastern part of the study area (figs. 2 and 10). The potentiometric surface reaches altitudes greater than $125 \mathrm{ft}$ above NGVD 29 in this area. The second smaller potentiometric high (sometimes referred to as the East Pasco High) is located west of the Withlacoochee River in Pasco County (figs. 2 and 10). The potentiometric surface in the area of the East Pasco High reaches altitudes greater than $85 \mathrm{ft}$ above NGVD 29. A small potentiometric high also was observed near the lower part of the Tsala Apopka Chain-of-Lakes during the May 2006 dry season (fig. 10B).

Potentiometric-surface contours indicate groundwater flow in the Upper Floridan aquifer within the Withlacoochee River watershed was predominantly northwest and west, with some to the north from the Green Swamp, and to the east from the East Pasco High toward the Withlacoochee River. Hydraulic gradients are toward the river, and potentiometric contours bend upstream near the river from Dade City northward to Rital (sites SW3 and SW6, fig. 2 and table 1) during September 2005, indicating groundwater flow toward the river (fig. 10A). During May 2006 (fig. 10B), the pattern was similar but extended farther north to Croom (site SW7, fig. 2 and table 1). Potentiometric contours also bend in an upstream direction along the Outlet River (site SW10, fig. 2 and table 1) to Lake Panasoffkee (fig. 2), indicating groundwater from the Upper Floridan aquifer was discharging to the surface-water system. The small potentiometric high near the Tsala Apopka Chain-of-Lakes is a result of water-level control structures designed to prevent extreme low water levels during dry periods. The water levels in the lake are normally maintained at a higher level than the groundwater levels, thereby recharging the Upper Floridan aquifer. Groundwater moves from this recharge area toward the river on the eastern side of this high and toward the coast on the western side (Southwest Florida Water Management District, 1994). While water levels in the lake also are controlled during the wet season, a potentiometric high is not evident on the September 2005 potentiometricsurface map because the differences are not as great between groundwater and lake levels. The slope of the potentiometric 

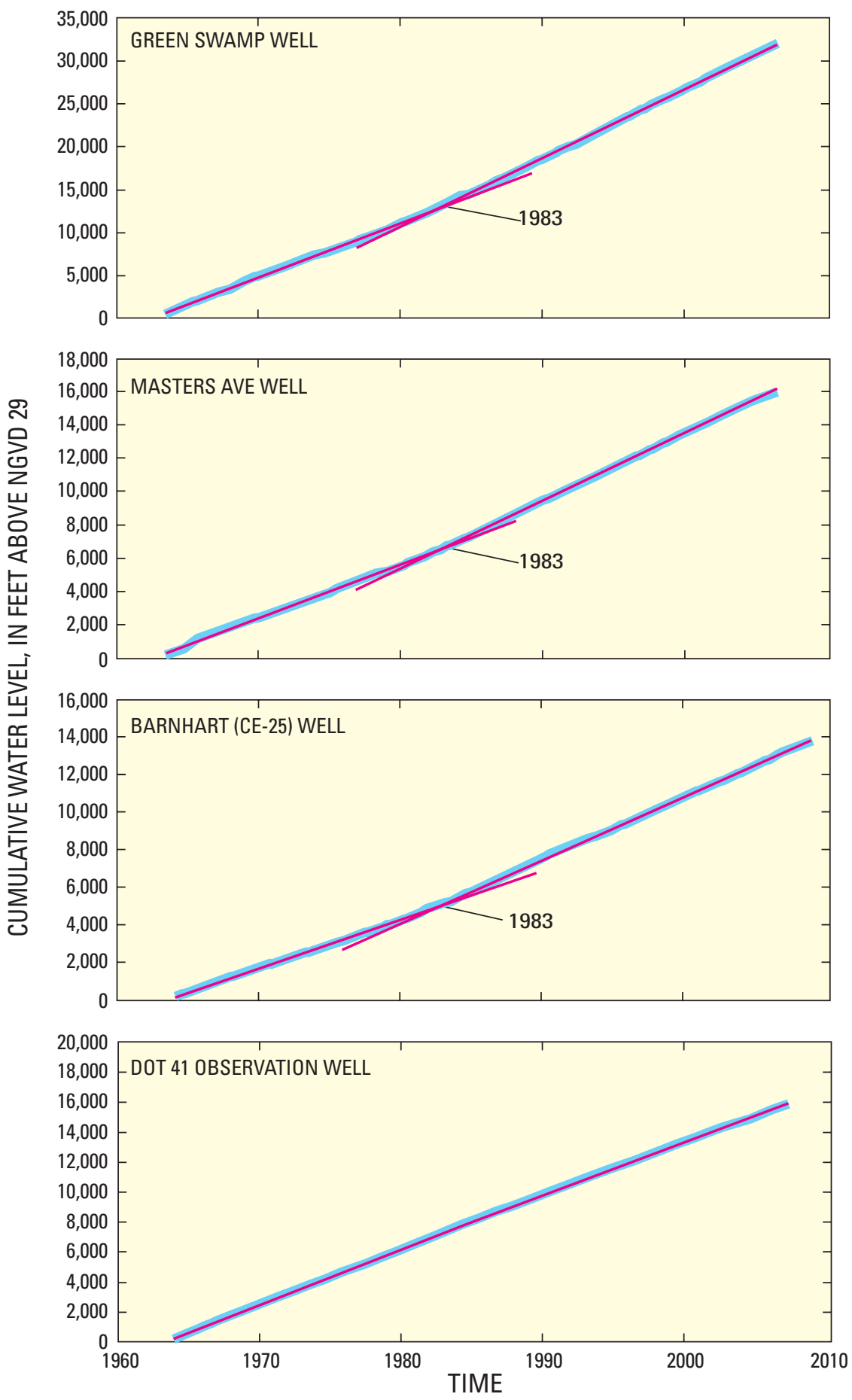

Figure 9. Cumulative water level in relation to time for the four Upper Floridan aquifer wells with long-term data. Site locations are shown in figure 7. 


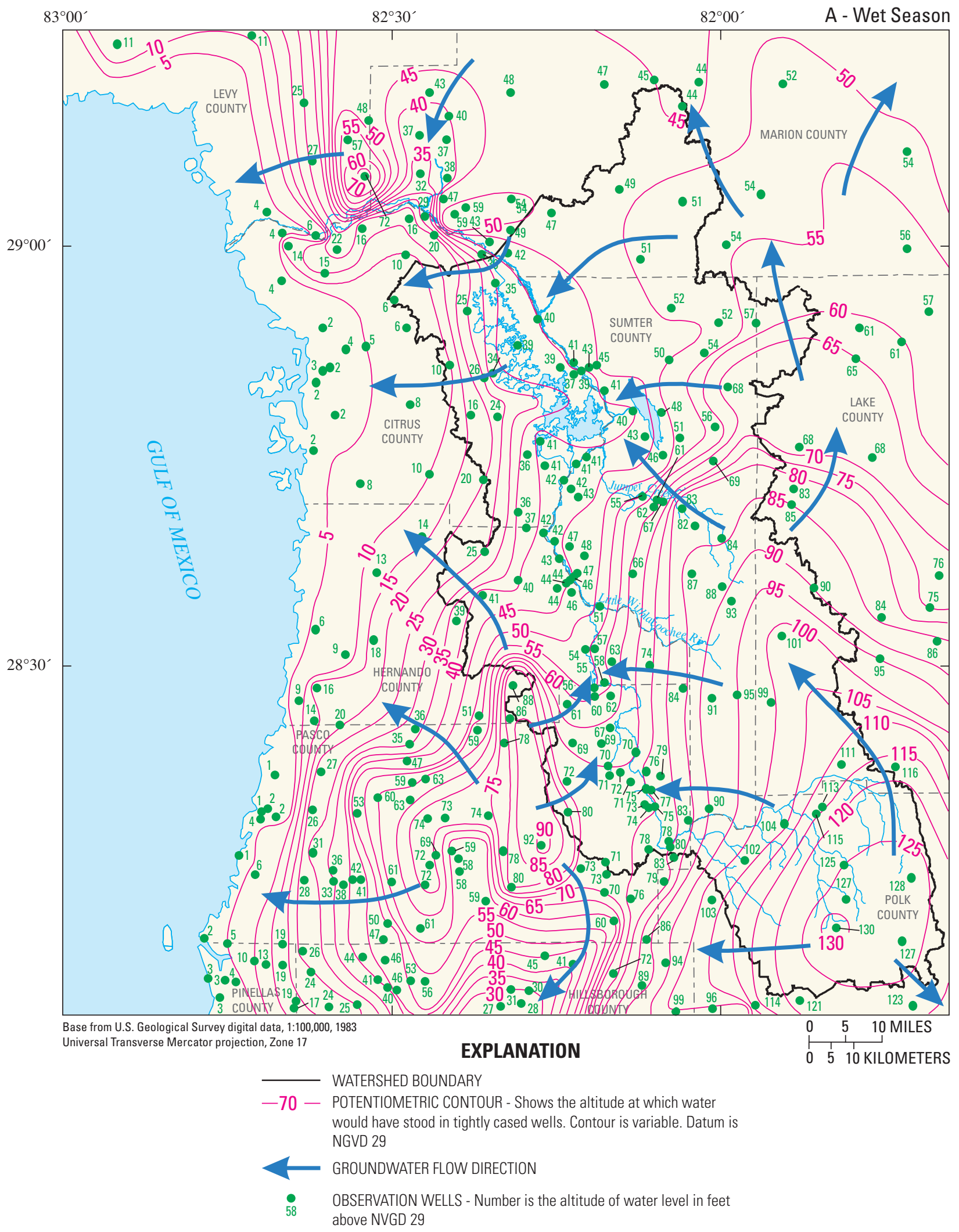

Figure 10A. Potentiometric surface of the upper Floridan aquifer in the Withlacoochee River watershed and adjacent areas, September 2005. Modified from Ortiz (2005). 


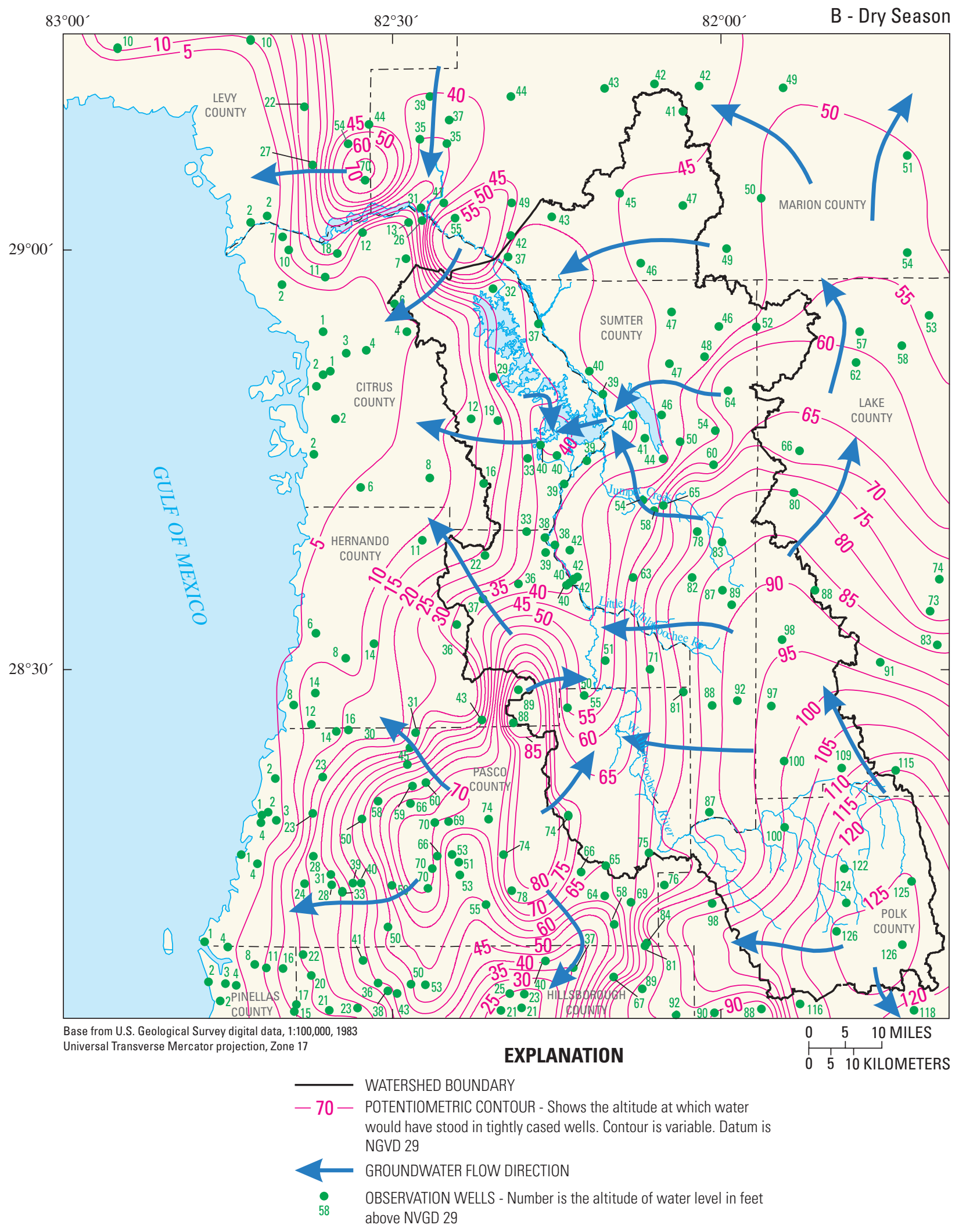

Figure 10B. Potentiometric surface of the upper Floridan aquifer in the Withlacoochee River watershed and adjacent areas, May 2006. Modified from Ortiz (2006). 
surface cuts across the river north of Croom, south of Dade City, and in the area of the Green Swamp, indicating less groundwater discharge from the Upper Floridan aquifer in these areas. Potentiometric contours shown in figures $10 \mathrm{~A}$ and $10 B$ vary slightly from the regional potentiometric-surface maps for the same period because more data points are included for the study area maps.

With the exception of the area around Lake Panasoffkee and the Tsala Apopka Chain-of-Lakes, differences in the potentiometric surface between September 2005 and May 2006 range from 3 to $6 \mathrm{ft}$ throughout most of the central part of the study area. Potentiometric-surface differences in the area of the lakes range from 0 to $3 \mathrm{ft}$. The impoundment of water in the Tsala Apopka Chain-of-Lakes and the Withlacoochee River in this area maintains relatively constant water levels in the lake and river, increasing recharge to the Upper Floridan aquifer and stabilizing water levels in the aquifer. Toward the coast and on the eastern side of the study area, potentiometric-surface differences also range from 0 to $3 \mathrm{ft}$. Areas with greater than $6 \mathrm{ft}$ of change are probably related to local conditions. Figure 11 shows the difference, in feet, in the potentiometric surface of the Upper Floridan aquifer between September 2005 and May 2006.

\section{Surface-Water Hydrology}

Thirteen gaging stations located between the Eva station (site SW1, fig. 2 and table 1) and the Holder station (site SW13, fig. 2 and table 1) were used for the study. Continuous streamflow data were collected at 12 stations. Periodic streamflow data were collected at the Eva station. Periodic water-quality samples were collected at seven gaging stations.

\section{Streamflow}

Continuous streamflow was observed in the Withlacoochee River from the Trilby station (site SW4, fig. 2) to the Holder station (site SW13, fig. 2) during the entire study period (October 2003 - March 2007). During wet periods, streamflow was influenced by direct runoff, inflow from tributaries, and storage and release of water from riverine wetlands, particularly those located at the headwaters in the Green Swamp area. During dry periods, groundwater discharging from the underlying Upper Floridan aquifer augments flow in the river. The hydrograph showing flow at the Holder station was a subdued reflection of the hydrograph at the upstream Trilby station (fig. 12A) because of increasing groundwater discharge to the river in the downstream direction and the controlled release of water through the Wysong Dam (site SW11, fig. 2).

In contrast, streamflow observed at the Cumpressco station (site SW2; fig. 2) near the Green Swamp was less constant, with 74 no-flow days occurring periodically during dry periods between October 2003 and September 2006 (fig. 12B). Of these no-flow days, 60 days occurred during a dry period in 2006, 11 days occurred in 2004, and only 3 days occurred in 2005. Rainfall was much below the 30-year normal (19752004) during 2006. Streamflow at the Dade City station downstream from Cumpressco (site SW3, fig. 2) was more constant, with only 9 no-flow days occurring during the 2006 dry period (fig. 12B). During wet periods, runoff causes streamflow peaks and recessions at the Cumpressco and Dade City stations to be more rapid and extreme than those observed at the Trilby and Holder stations. Confinement between surficial deposits and the Upper Floridan aquifer is greater in the Green Swamp area than in areas farther downstream in the watershed (Grubb and Rutledge, 1978).

Cumulative mean daily streamflow data for the Withlacoochee River near Cumpressco, Withlacoochee River at Trilby, and the Withlacoochee River near Holder stations were plotted against time. A slope change around 1970 is evident in the data for all three stations (fig. 13). The slope for the 1970-2000 period is less steep than the pre-1970 slope, indicating a trend toward lower streamflow. A second, increasing slope change is evident around 2000 at the Cumpressco and Trilby stations, but not at the Holder station. The absence of a clear change in slope at the Holder station may be related to the storage and controlled release of water from the Wysong Dam (fig. 2). The slope for the 2000-06 period is steeper than the slope for the 1970-2000 period at the Cumpressco and Trilby stations, indicating a possible trend toward higher streamflow.

Analysis of rainfall by Basso and Shultz (2003) indicates that there has been no statistically significant change in annual rainfall over the last century; however, when the record was partitioned into shorter intervals, several cycles of above and below average rainfall were evident. According to their study, the period between 1940 and 1969 was wetter than the period between 1970 and 1999. A study by Enfield and others (2001) also found differences in pre- and post-1970 rainfall. This period is similar to the natural variation in North Atlantic sea surface temperature cycles that occurs every 20 to 50 years, referred to by Kerr (2000) as the Atlantic Multidecadal Oscillation (AMO). Kelley (2004) examined rainfall and river flow in west-central Florida and determined trends related to the AMO. The 1970 slope change of cumulative streamflow data for the Cumpressco, Trilby, and Holder gaging stations coincides with the AMO- related wetter pre- and drier post-1970 rainfall cycles discussed by Enfield and others (2001) and Kelley (2004).

\section{Flow Duration}

Discharge-duration curves are cumulative frequency curves that show the percentage of time that the daily mean discharge of a stream equals or exceeds a given value during a specific period. The shape of the curve reflects the characteristics of the watershed upstream from the station. A flatter slope indicates flood plain storage or groundwater-dominated systems, whereas a steeper slope indicates less storage or groundwater contributions (Searcy, 1959). Duration curves were developed for the period between 1967 and 2006 to 


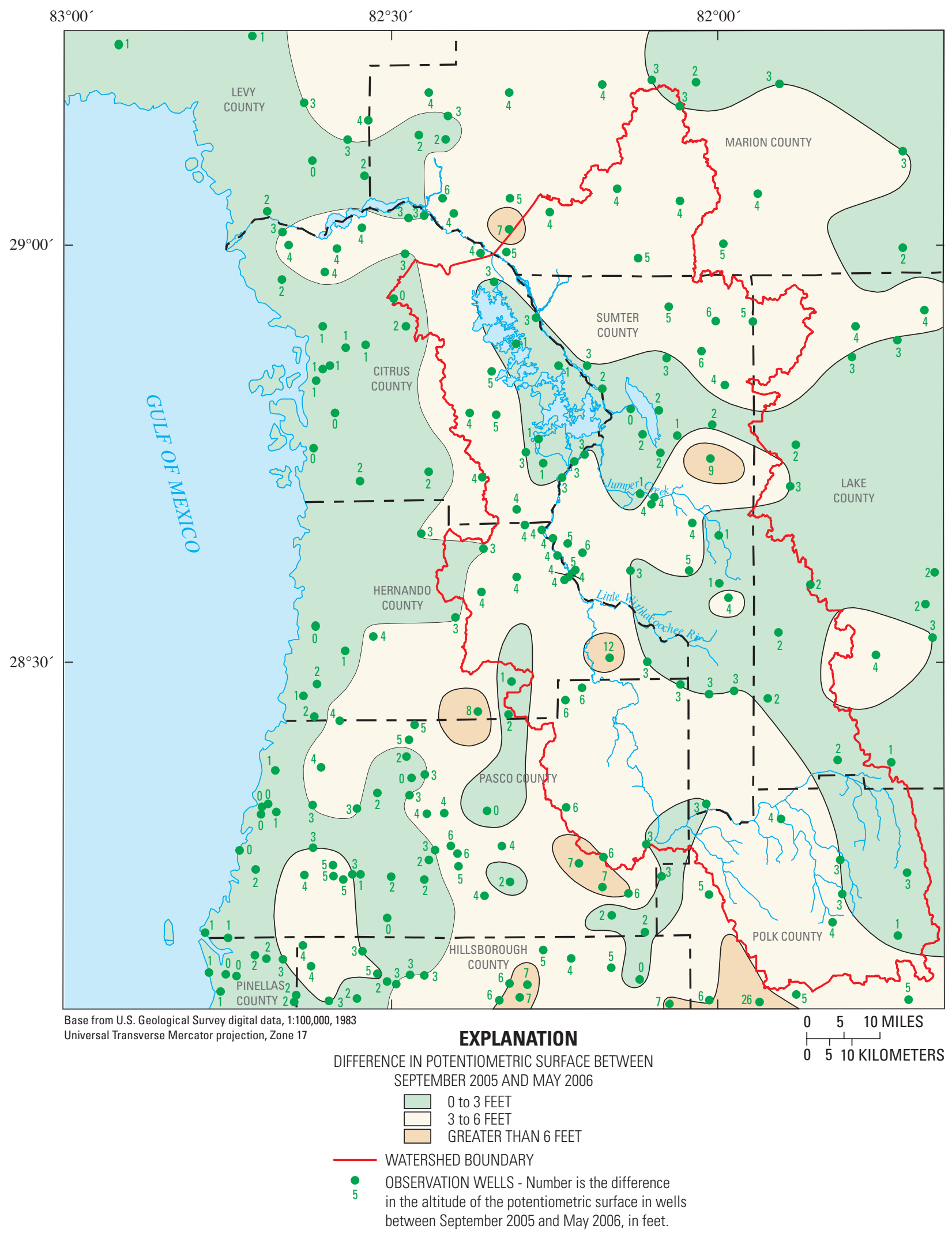

Figure 11. Difference in the potentiometric surface of the Upper Floridan aquifer in the Withlacoochee River watershed and adjacent areas between September 2005 and May 2006. 


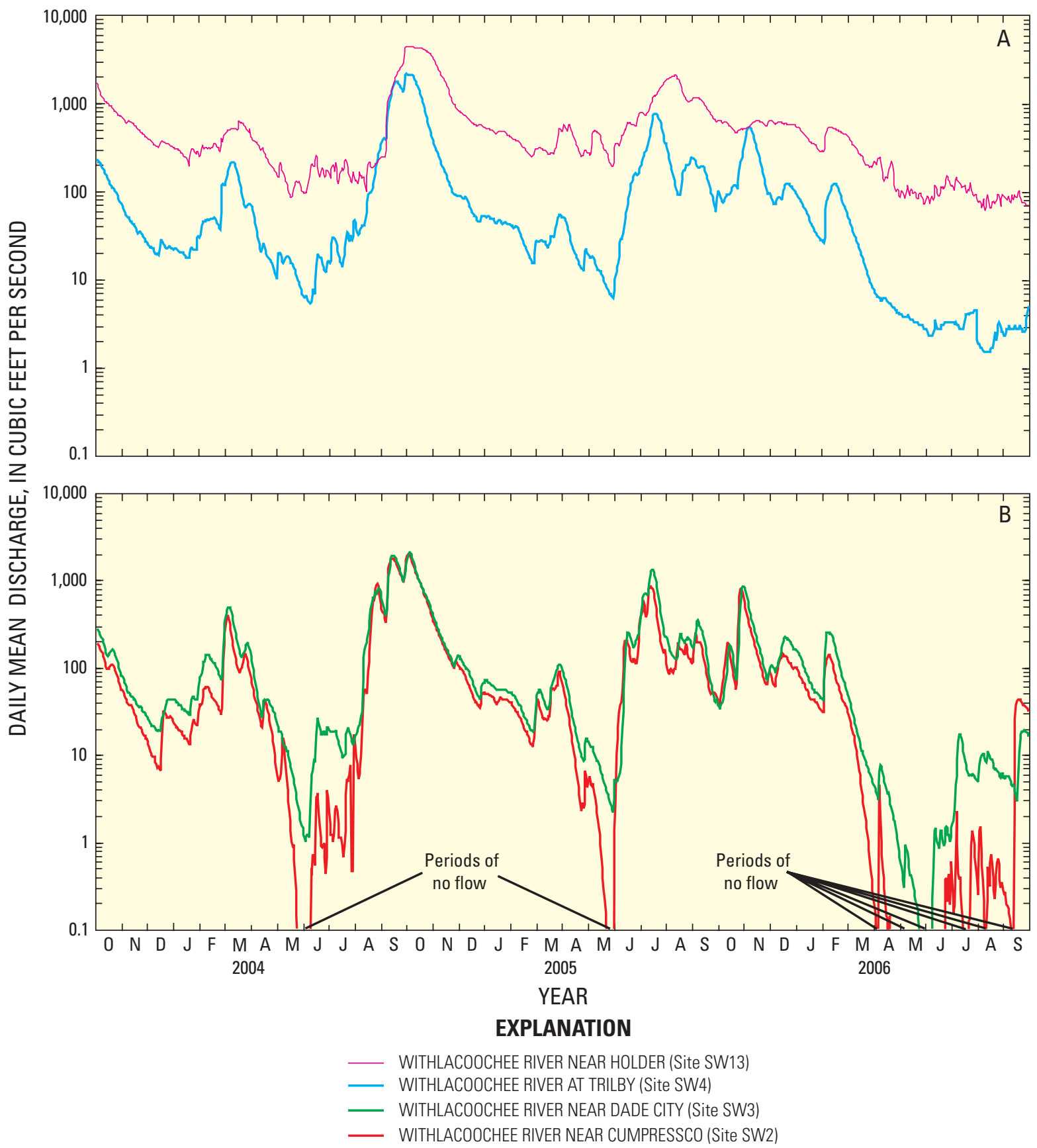

Figure 12. Daily mean discharge at $A$, the Withlacoochee River near Holder and at Trilby stations, and $B$, the Withlacoochee River near Dade City and Cumpressco stations, 2004-06 water years. Site locations are shown in figure 2 and described in table 1. 


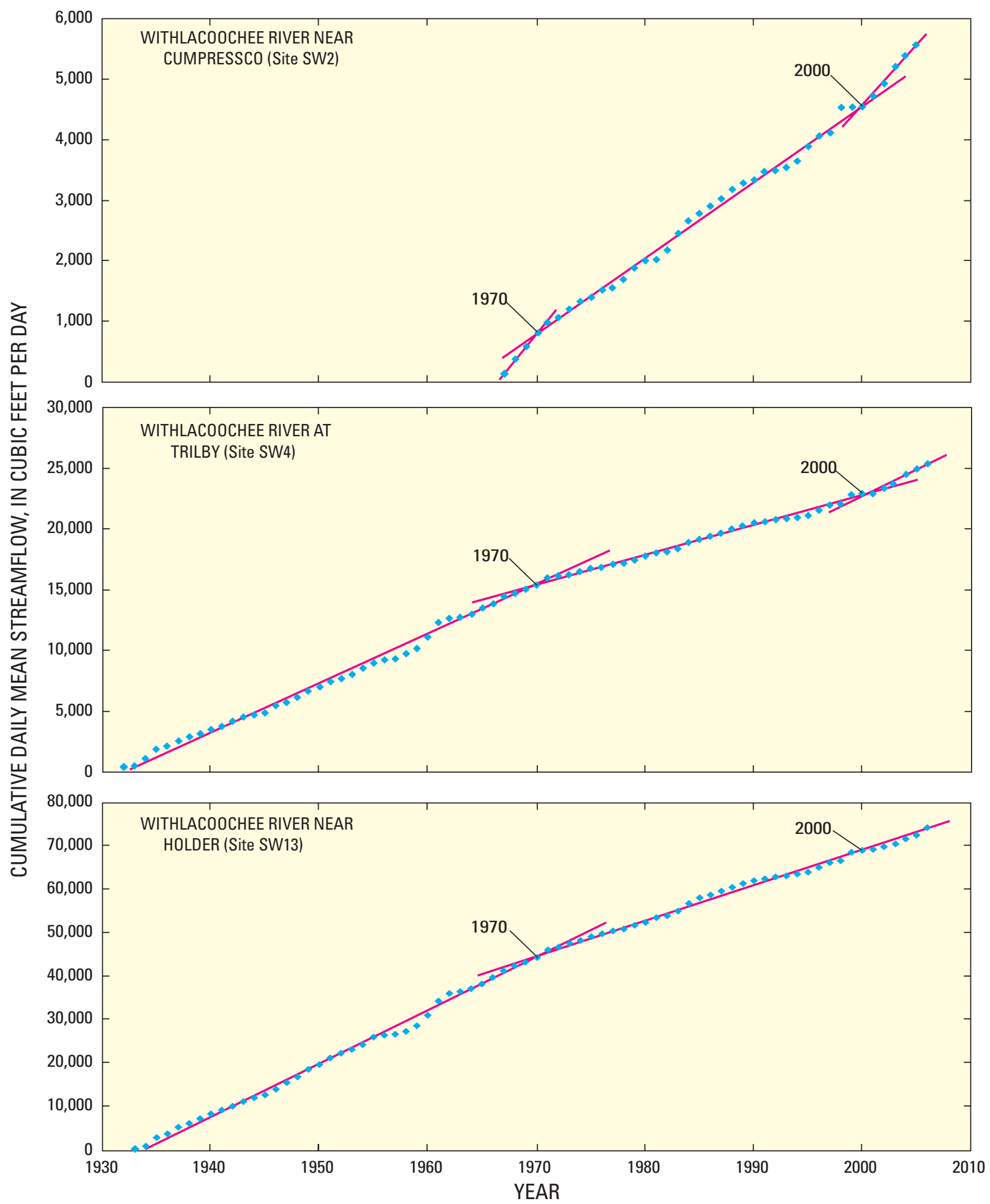

Figure 13. Cumulative daily mean streamflow in relation to time for the Withlacoochee River near Cumpressco, at Trilby, and near Holder stations. Site locations are shown in figure 2. 
allow comparison between the Withlacoochee River near Cumpressco, Withlacoochee River near Dade City, Withlacoochee River at Trilby, and the Withlacoochee River near Holder stations (fig. 14A). Duration curves also were calculated for the study period (2004-06) at these stations (fig. 14B) to compare current and historical flow characteristics.

Duration curves developed for the period from 1967 to 2006 are not as steep for the Holder and Trilby gaging stations as curves developed for the Dade City and Cumpressco stations (fig. 14A). The low end of the curves (greater than 95-percent exceedance level) for the Holder and Trilby stations never reach zero flow. Groundwater discharge, the storage and release of water from riverine wetlands along the flood plain and, for the Holder station, the controlled release of water at the Wysong Dam (site SW11, fig. 2) have a stabilizing effect on flow in these sections of the Withlacoochee River. The curves for the Dade City and Cumpressco stations are steeper, declining more rapidly than at the Holder and Trilby stations, indicating less groundwater influence on streamflow at the Dade City and Cumpressco stations. Lack of groundwater inflow also is demonstrated by no-flow days that occurred during dry periods throughout the study period (fig. 12B).

Duration curves developed for the study period (2004-06) for the Holder, Trilby, Dade City, and Cumpressco stations are similar in shape and slope to duration curves developed for the period of record. The low end of the curves for the Holder and Trilby stations never reach zero flow, indicating stable and constant flow during the study period (fig. 14B). The duration curve developed at the Dade City station is not as steep for the study period as for the period from 1967 to 2006. The curve declines rapidly at the lower end (greater than 90-percent exceedance level) almost reaching zero flow, indicating more groundwater influence on streamflow during the study period than during the 1967-2006 period (fig. 14A). The slope of the curve developed for the Cumpressco station for the study period is slightly flatter below the 60-percent exceedance level than the 1967-2006 period curve, indicating that wetlands in the Green Swamp were on average contributing a greater amount of streamflow during the study period than during the 1967-2006 period. Above the 60-percent exceedance level, the curves for the 1967-2006 period and the study period at the Cumpressco station are similar, with both declining to zero flow, indicating that groundwater does not have as much of a stabilizing influence on streamflow (fig. 14).

At the Trilby, Dade City, and Cumpressco stations shown in figure 14, historical streamflow (1967-2006) at exceedance levels less than or equal to 30 percent were more often greater than during the study period. High flow events at these stations occurred less often during the study period than during the 1967-2006 period. However, streamflow at exceedance levels greater than 30 percent was historically smaller at these stations than during the study period (fig. 14). More discharge occurred in the mid-to-low flow range during the study period than during the period of record. Lower than normal rainfall in 2006 affected streamflow during the study period. Streamflow at the Holder station was greater during the study period than during the 1967-2006 period over the entire range of exceedance levels.

\section{Surface-Water and Groundwater Interactions}

Examination of surface-water altitude data, surficial aquifer and shallow and deep Floridan aquifer system water levels, and water-quality data for the Withlacoochee River watershed indicates that a good hydraulic connection exists between the shallow and deep groundwater systems and the surface-water system. Depending on the location and seasonal conditions, water can discharge from the aquifers to the streams or from the streams to the underlying aquifer. Seepage runs were conducted to determine the quantity of water flowing from or lost to the groundwater system. Base-flow hydrograph separation analyses were conducted to characterize groundwater discharge to the river. Water-quality analysis was used to establish the linkage between the river and groundwater flow system. Hydraulic analysis of the groundwater system at a cross section was conducted to characterize the linkage between groundwater and surface water. A geophysical seismic-reflection survey was conducted to identify seismic reflectors that could be correlated to hydrogeologic units and karst features.

\section{Streamflow Gains and Losses}

Synoptic streamflow measurements were made at 21 locations along the Withlacoochee River, 8 tributaries, and 6 springs (fig. 15 and table 3). Streamflow gains or losses were estimated from measurements made during three low-flow seepage runs conducted in May 2004, April 2005, and April 2006. The highest flows were measured during the April 2005 seepage run when streamflow at the Holder station (site R21, fig. 15) was about $652 \mathrm{ft}^{3} / \mathrm{s}$. Streamflow was lower at all locations during the May 2004 and April 2006 seepage runs, when discharge at the Holder station was about 355 and $411 \mathrm{ft}^{3} / \mathrm{s}$, respectively. Surface-water outflow from the river to a tributary was observed once during the seepage runs at site T28 (fig. 15 and table 3) during 2005. All other tributaries did not flow, or discharge into the river during the seepage runs. Summaries of streamflow measurements, and computed net seepage gains and losses for the four reaches are presented in tables 4 to 6 .

Streamflow data collected under low-flow conditions during the study period, with the exception of a few sites that can gain or lose water, indicated that the river was a gaining stream. Net seepage gains of about 165 and $162 \mathrm{ft}^{3} / \mathrm{s}$ from groundwater was calculated for the entire study reach for the seepage runs in May 2004 and April 2006, respectively (table 7). A net seepage gain of about $272 \mathrm{ft}^{3} / \mathrm{s}$ was calculated for the seepage run in April 2005 (table 7). Groundwater levels in the Upper Floridan aquifer were generally higher during the 2005 seepage run than during the 2004 and 2006 seepage runs; however, water levels in some wells near the Green Swamp had similar water levels during all three seepage runs. The streamflow balance for the Withlacoochee River near Holder for the three seepage runs is shown in figure 16. The flow 


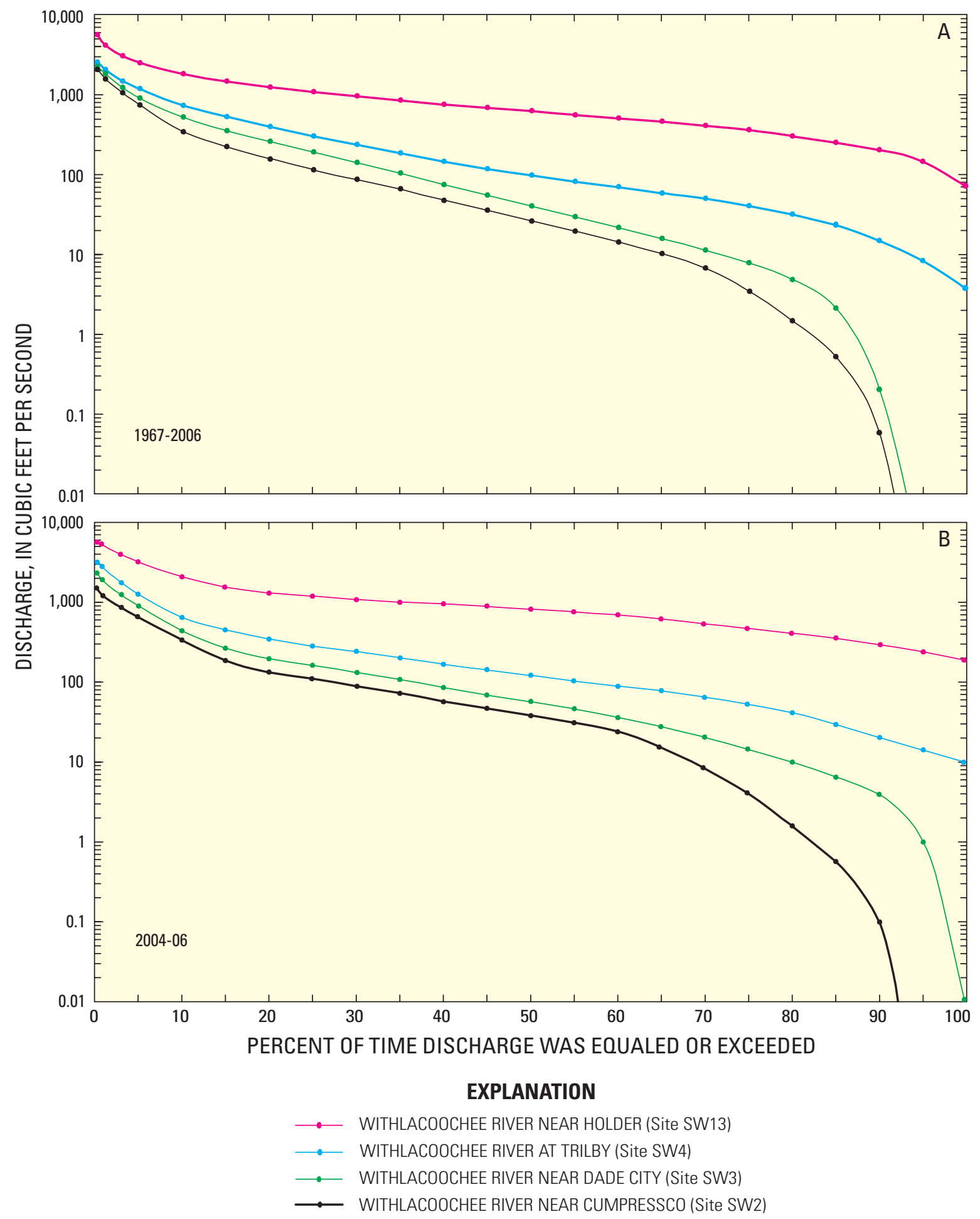

Figure 14. Duration curves of daily mean discharge at the Withlacoochee River near Holder, at Trilby, near Dade City, and near Cumpressco stations for $A$, the period between 1967 and 2006, and $B$, the study period (2004-06). Site locations are shown in figure 2. 


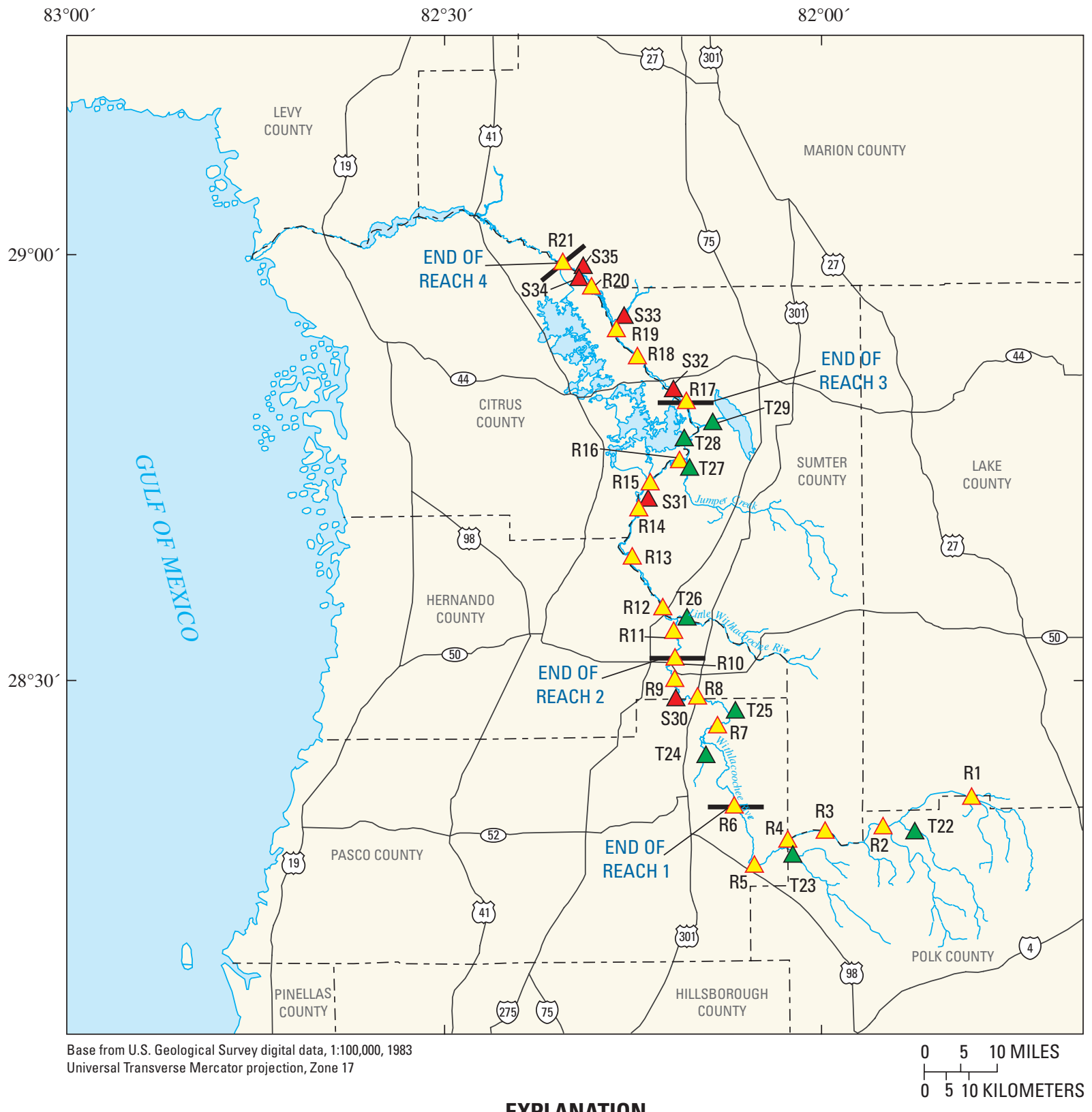

\section{EXPLANATION}

$\triangle$ R1 RIVER MEASURING SITE AND NUMBER

$\triangle$ T27 TRIBUTARY MEASURING SITE AND NUMBER

$\triangle$ S3O SPRING MEASURING SITE AND NUMBER

Figure 15. Location of streamflow measurement sites and seepage reaches. Site locations described in table 3. 
Table 3. Streamflow sites measured during the seepage runs.

[Latitude and longitude in degrees, minutes, seconds in North American Datum of 1983 (NAD83)]

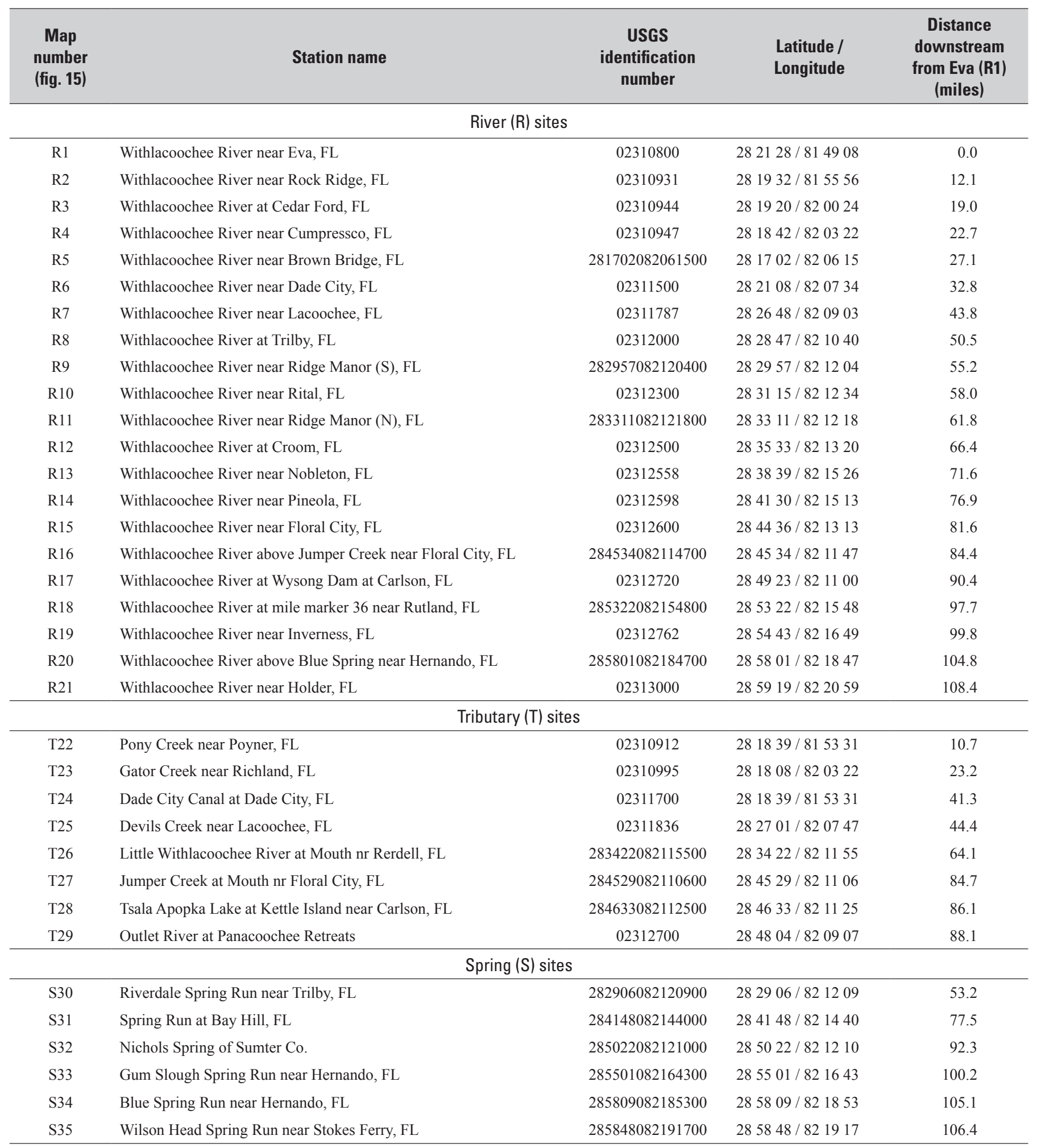


Table 4. Streamflow balance and specific conductance of water for the May 2004 seepage run.

[Seepage loss and rate of loss are shown in red. $\mathrm{ft}^{3} / \mathrm{s}$, cubic feet per second; $\mathrm{ft}^{3} / \mathrm{s} / \mathrm{mi}$, cubic feet per second per mile; $\mu \mathrm{S} / \mathrm{cm}$, microsiemens per centimeter at $25^{\circ} \mathrm{C}$; --, no data]

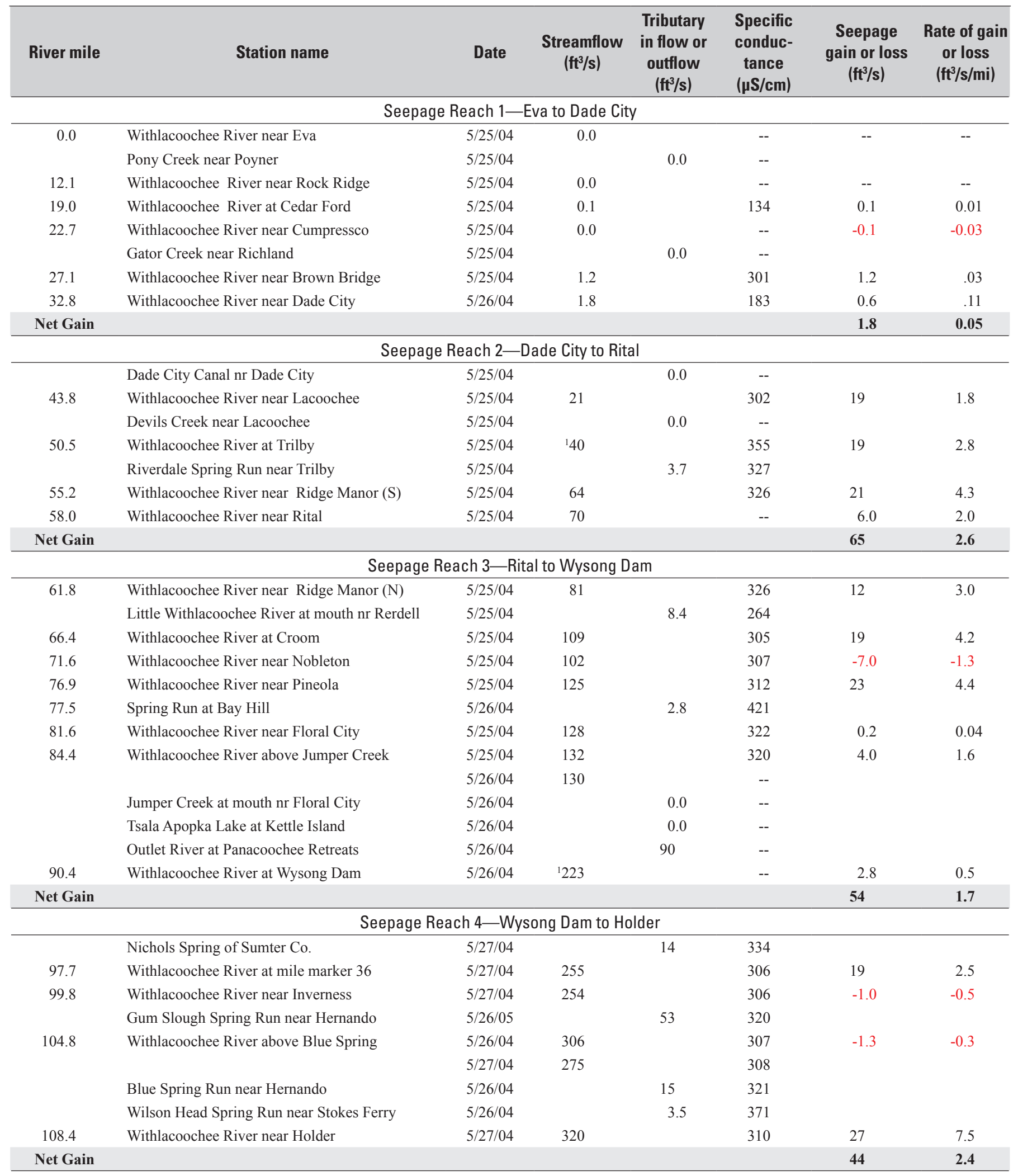

${ }^{1}$ Daily mean discharge 
Table 5. Streamflow balance and specific conductance of water for the April 2005 seepage run.

[Seepage loss and rate of loss are shown in red. $\mathrm{ft}^{3} / \mathrm{s}$, cubic feet per second; $\mathrm{ft}^{3} / \mathrm{s} / \mathrm{mi}$, cubic feet per second per mile; $\mu \mathrm{S} / \mathrm{cm}$, microsiemens per centimeter at $25^{\circ} \mathrm{C}$; --, no data]

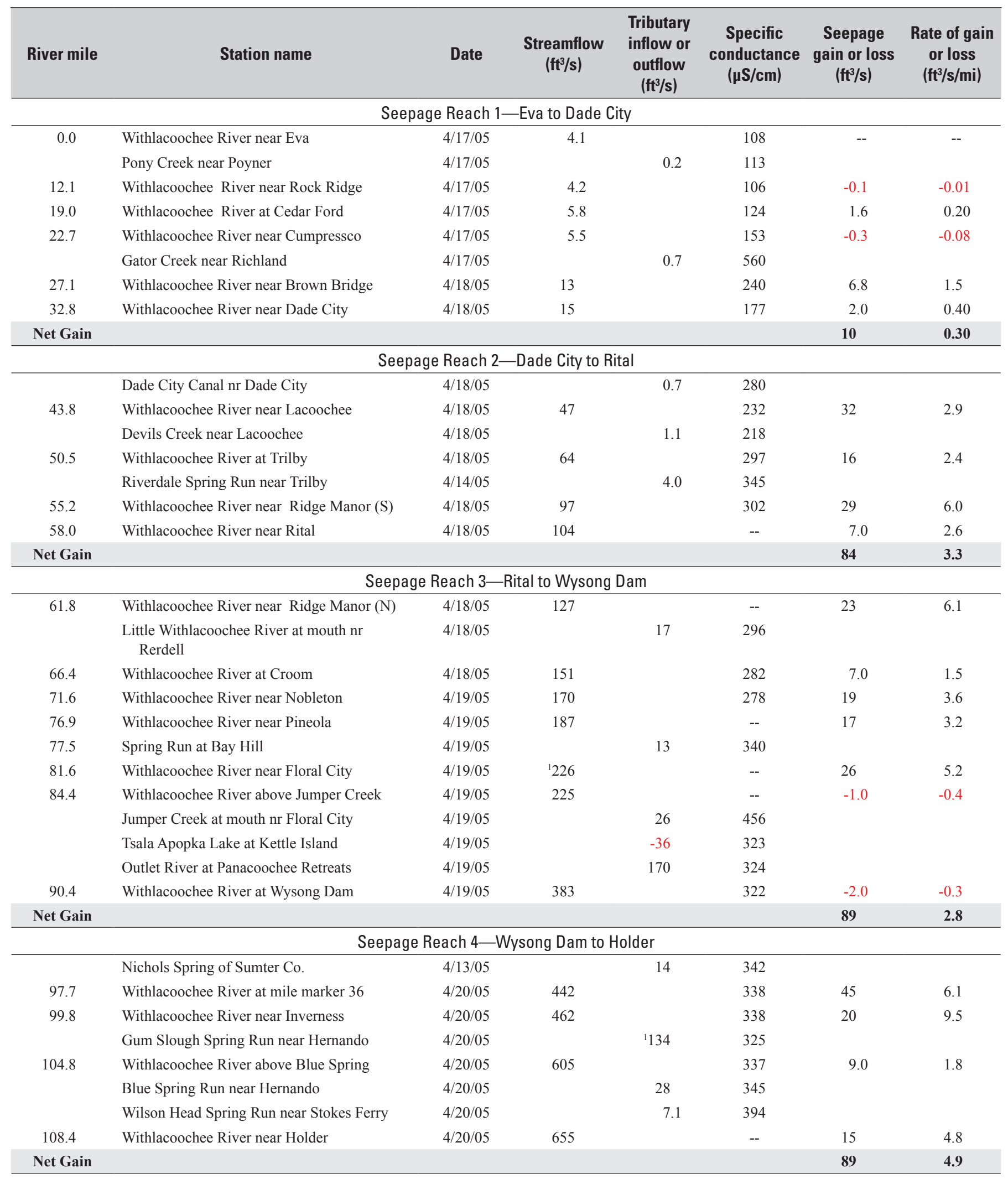

${ }^{1}$ Daily mean discharge 
Table 6. Streamflow balance and specific conductance of water for the April 2006 seepage run.

[Seepage loss and rate of loss are shown in red. $\mathrm{ft}^{3} / \mathrm{s}$, cubic feet per second; $\mathrm{ft}^{3} / \mathrm{s} / \mathrm{mi}$, cubic feet per second per mile; $\mu \mathrm{S} / \mathrm{cm}$, microsiemens per centimeter at $25^{\circ} \mathrm{C}$; --, no data]

\begin{tabular}{|c|c|c|c|c|c|c|c|}
\hline $\begin{array}{l}\text { River } \\
\text { mile }\end{array}$ & Station name & Date & $\begin{array}{c}\text { Streamflow } \\
\left(\mathrm{ft}^{3} / \mathrm{s}\right)\end{array}$ & $\begin{array}{c}\text { Tributary } \\
\text { inflow } \\
\text { or outflow } \\
\left(\mathrm{ft}^{3} / \mathrm{s}\right)\end{array}$ & $\begin{array}{c}\text { Specific } \\
\text { conductance } \\
\text { ( } \mathrm{S} / \mathrm{cm})\end{array}$ & $\begin{array}{c}\text { Seepage } \\
\text { gain } \\
\text { or loss } \\
\text { (ft } 3 / \mathrm{s})\end{array}$ & $\begin{array}{c}\text { Rate of gain } \\
\text { or loss } \\
\left(\mathrm{ft}^{3} / \mathrm{s} / \mathrm{mi}\right)\end{array}$ \\
\hline \multirow[t]{2}{*}{0.0} & Withlacoochee River near Eva & $4 / 18 / 06$ & 0.0 & & -- & -- & -- \\
\hline & Pony Creek near Poyner & $4 / 18 / 06$ & & 0.0 & -- & & \\
\hline \multirow[t]{2}{*}{22.7} & Withlacoochee River near Cumpressco & $4 / 18 / 06$ & 0.1 & & 398 & 0.0 & 0.00 \\
\hline & Gator Creek near Richland & $4 / 18 / 06$ & & 0.0 & -- & & \\
\hline 27.1 & Withlacoochee River near Brown Bridge & $4 / 18 / 06$ & 3.4 & & 422 & 3.3 & 0.80 \\
\hline 32.8 & Withlacoochee River near Dade City & $4 / 18 / 06$ & 4.2 & & 201 & 0.8 & 0.10 \\
\hline Net Gain & & & & & & 4.2 & 0.10 \\
\hline 43.8 & Devils Creek near Lacoochee & $4 / 18 / 06$ & & 0.0 & -- & & \\
\hline \multirow[t]{2}{*}{50.5} & Withlacoochee River at Trilby & $4 / 19 / 06$ & 34 & & 359 & 15 & 2.3 \\
\hline & Riverdale Spring Run near Trilby & $4 / 18 / 06$ & & 3.8 & 354 & & \\
\hline 55.2 & Withlacoochee River near Ridge Manor (S) & $4 / 19 / 06$ & 50 & & -- & 12 & 2.5 \\
\hline 58.0 & Withlacoochee River near Rital & $4 / 19 / 06$ & 55 & & -- & 5.1 & 1.8 \\
\hline Net Gain & & & & & & 47 & 1.9 \\
\hline \multicolumn{8}{|c|}{ Seepage Reach 3-Rital to Wysong Dam } \\
\hline \multirow[t]{2}{*}{61.8} & Withlacoochee River near Ridge Manor (N) & $4 / 19 / 06$ & 61 & & 346 & 6.0 & 1.6 \\
\hline & Little Withlacoochee River at mouth $\mathrm{nr}$ Rerdell & $4 / 19 / 06$ & & 8.6 & -- & & \\
\hline 66.4 & Withlacoochee River at Croom & $4 / 19 / 06$ & 71 & & 350 & 1.4 & 0.30 \\
\hline \multirow{2}{*}{84.4} & Tsala Apopka Lake at Kettle Island & $4 / 19 / 06$ & & 0.00 & 328 & & \\
\hline & Outlet River at Panacoochee Retreats & $4 / 19 / 06$ & & ${ }^{1} 126$ & 382 & & \\
\hline 90.4 & Withlacoochee River at Wysong Dam & $4 / 19 / 06$ & ${ }^{2} 270$ & & 317 & 4.0 & 0.70 \\
\hline Net Gain & & & & & & 40 & 1.4 \\
\hline \multicolumn{8}{|c|}{ Seepage Reach 4-Wysong Dam to Holder } \\
\hline & Nichols Spring of Sumter Co. & $4 / 19 / 06$ & & 14 & 383 & & \\
\hline 97.7 & Withlacoochee River at mile marker 36 & $4 / 20 / 06$ & ${ }^{3} 333$ & & 349 & 49 & 6.8 \\
\hline \multirow[t]{2}{*}{99.8} & Withlacoochee River near Inverness & -- & 2312 & & 347 & -21 & -10 \\
\hline & Gum Slough Spring Run near Hernando & $4 / 20 / 06$ & & 77 & -- & & \\
\hline \multirow[t]{3}{*}{104.8} & Withlacoochee River above Blue Spring & $4 / 20 / 06$ & 407 & & 335 & 18 & 3.5 \\
\hline & Blue Spring Run near Hernando & $4 / 25 / 06$ & & 14 & 328 & & \\
\hline & Wilson Head Spring Run near Stokes Ferry & $4 / 25 / 06$ & & 3.2 & 382 & & \\
\hline 108.4 & Withlacoochee River near Holder & -- & $449^{2}$ & & 334 & 25 & 7.0 \\
\hline Net Gain & & & & & & 71 & 3.9 \\
\hline
\end{tabular}

${ }^{1}$ Daily mean discharge.

23-day mean discharge for 4/20-22/2006.

${ }^{3}$ Estimated. 
Table 7. Summary of net seepage gains and losses for the 20 subreaches along the Withlacoochee River.

[Seepage is in cubic feet per second. Seepage losses are shown in red]

\begin{tabular}{|c|c|c|c|}
\hline \multirow{2}{*}{ Subreach ${ }^{1}$} & \multicolumn{3}{|c|}{ Seepage } \\
\hline & May 2004 & April 2005 & April 2006 \\
\hline \multicolumn{4}{|c|}{ Reach $1^{1}$} \\
\hline Eva (R1) to Rock Ridge (R2) & 0.00 & $-0.10^{2}$ & 0.10 \\
\hline Rock Ridge (R2) to Cedar Ford (R3) & 0.01 & 1.6 & 0.00 \\
\hline Cedar Ford (R3) to Cumpressco (R4) & $-0.01^{2}$ & $-0.30^{2}$ & 0.00 \\
\hline Cumpressco (R4) to Brown Bridge (R5) & 1.20 & 6.80 & 3.30 \\
\hline Brown Bridge (R5) to Dade City (R6) & 0.60 & 2.00 & 0.80 \\
\hline Subtotal for reach 1 & 1.8 & 10 & 4.2 \\
\hline \multicolumn{4}{|c|}{ Reach $2^{1}$} \\
\hline Dade City (R6) to Lacoochee (R7) & 19 & 32 & 15 \\
\hline Lacoochee (7) to Trilby (R8) & 19 & 16 & 15 \\
\hline Trilby (R8) to Ridge Manor (S) (R9) & 21 & 29 & 12 \\
\hline Ridge Manor (S) (R9) to Rital (R10) & 6.0 & 7.0 & 5.1 \\
\hline Subtotal for reach 2 & 65 & 84 & 47 \\
\hline \multicolumn{4}{|c|}{ Reach $3^{1}$} \\
\hline Rital (R10) to Ridge Manor (N) (R11) & 12 & 23 & 6.0 \\
\hline Ridge Manor (N) (R11) to Croom (R12) & 19 & 7.0 & 1.4 \\
\hline Croom (R12) to Nobleton (R13) & -7.0 & 19 & $-3.0^{2}$ \\
\hline Nobleton (R13) to Pineola (R14) & 23 & 17 & 26 \\
\hline Pineola (R14) to Floral City (R15) & 0.20 & 26 & $-5.3^{2}$ \\
\hline Floral City (R15) to Jumper Creek (R16) & 4.0 & $-1.0^{2}$ & 11 \\
\hline Jumper Creek (R16) to Wysong Dam (R17) & 2.8 & -2.0 & 4.0 \\
\hline Subtotal for reach 3 & 54 & 89 & 40 \\
\hline \multicolumn{4}{|c|}{ Reach $4^{1}$} \\
\hline Wysong Dam (R17) to mile marker 36 (R18) & 19 & 45 & 49 \\
\hline Mile marker 36 (R18) to Inverness (R19) & -1.0 & 20 & -21 \\
\hline Inverness (R19) to Blue Spring (R20) & -1.3 & 9.0 & 18 \\
\hline Blue Spring (R20) to Holder (R21) & 27.0 & 15.0 & 25 \\
\hline Subtotal for reach 4 & 44 & 89 & 71 \\
\hline Net Gain & 165 & 272 & 162 \\
\hline
\end{tabular}

${ }^{1}$ Reaches and subreaches are shown in figures 15 and 17 and described in table 3.

${ }^{2}$ Gain or loss is not statistically significant.

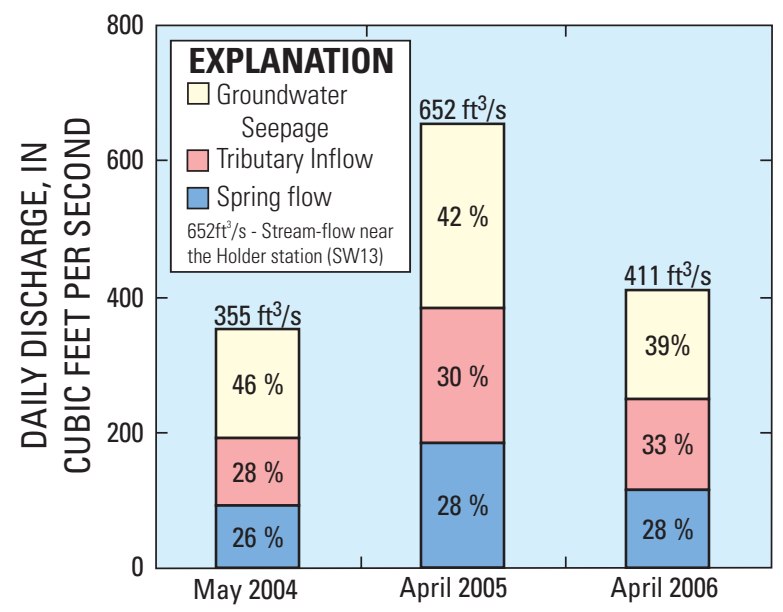

Figure 16. Streamflow balance for the Withlacoochee River near Holder station (Site SW13). 
components at this station were relatively stable, ranging from 39 to 46 percent for groundwater seepage, 26 to 28 percent for spring flow, and from 28 to 33 percent for tributary inflow. The highest percentage of groundwater seepage coincided with the lowest total surface-water flow. Spring flow was correlated with surface-water flow, increasing with river flow.

The generalized patterns of net seepage gains and losses for the 20 subreaches of the Withlacoochee River during the three seepage runs are shown in figure 17. Net seepage gains were identified for 16 subreaches; however, apparent seepage gains or losses were less than the accuracy of the measurement at four of these subreaches during two of the three seepage runs, and are therefore, indeterminate (table 7). The direction of exchange was mixed in four other subreaches, which are labeled "variable" in figure 17. River water recharged the groundwater system at these four subreaches during at least one seepage run.

\section{Reach 1}

Reach 1 is about $32.8 \mathrm{mi}$ long, extending from the farthest upstream USGS gaging station 02310800 at Eva to the USGS gaging station 02311500 at Dade City (sites R1 and R6, fig. 15). When streamflow was observed, measurements were made at two USGS gaging stations (sites R4 and R6, fig. 15 and table 3), four ungaged sites (sites R1, R2, R3, and R5, fig.15 and table 3), and two tributaries (sites T22 and T23, fig.15 and table 3) during each of the seepage runs. Inflow from tributaries ranged between 0 and 6 percent of the total flow through this reach. River flow increased over this reach because of groundwater seepage during all three seepage runs, averaging about $5.3 \mathrm{ft}^{3} / \mathrm{s}$, or about 1 percent of the average river flow exiting the study area at the Holder station (site R21, fig. 15). The largest gain measured for reach 1 was about $10 \mathrm{ft}^{3} / \mathrm{s}$, or about $0.3 \mathrm{ft}^{3} / \mathrm{s} / \mathrm{mi}$, in April 2005. The smallest gain was about $1.8 \mathrm{ft}^{3} / \mathrm{s}$, or about $0.05 \mathrm{ft}^{3} / \mathrm{s} / \mathrm{mi}$, in May 2004 (tables 4-6).

A net seepage gain was calculated for Reach 1 for all three seepage runs; however, some of the gains or losses calculated for the subreaches between Eva and Cumpressco were less than the accuracy of the measurement and were considered indeterminate (table 7). No flow was observed along the subreach from Eva to Rock Ridge (sites R1 and R2, fig. 15) in May 2004, and calculated gains or losses during the April 2005 and 2006 seepage runs were less than the measurement accuracy. Net seepage gains ranged from 0.0 to $1.6 \mathrm{ft}^{3} / \mathrm{s}$ along the subreach from Rock Ridge to Cedar Ford (sites R2 and R3, fig. 15 and table 7). The calculated gain during the May 2004 seepage run was less than the measurement accuracy (table 7), and no gain or loss was calculated for April 2006. Losses calculated along the subreach from Cedar Ford to Cumpressco (sites R3 and R4, fig. 15) for the May 2004 and April 2005 seepage runs also were less than the measurement accuracy, and no gain or loss was calculated for April 2006. Consistent net gains for all seepage runs were calculated for the subreaches between Cumpressco, Brown Bridge, and
Dade City (sites R4, R5 and R6, fig. 15). Most of the gains for each seepage run were concentrated between Cumpressco and Brown Bridge. About two-thirds of calculated gains for Reach 1 are from this subreach (tables 4-7).

\section{Reach 2}

Reach 2 is about $25.2 \mathrm{mi}$ long and extends from the USGS gaging station 02311500 at Dade City to the USGS gaging station 02312300 at Rital (sites R6 and R10, fig. 15). Measurements were made at three USGS gaging stations (sites R6, R8, and R10, fig. 15 and table 3), two ungaged sites (sites R7 and R9, fig. 15 and table 3), and at one spring (site S30, fig. 15 and table 3) during each of the seepage runs. River flow consistently increased over this reach because of seepage from the groundwater system. Mean groundwater seepage for Reach 2 for the three seepage runs was about $65 \mathrm{ft}^{3} / \mathrm{s}$, which was about 14 percent of the average river flow measured at the Holder station (site R21, fig. 15). The largest gain calculated for Reach 2 was about $84 \mathrm{ft}^{3} / \mathrm{s}$, or about $3.3 \mathrm{ft}^{3} / \mathrm{s} / \mathrm{mi}$, in April 2005. The smallest gain was about $47 \mathrm{ft}^{3} / \mathrm{s}$, or about $1.9 \mathrm{ft}^{3} / \mathrm{s} / \mathrm{mi}$, in April 2006 (tables 4-6).

About 90 percent of the net gain calculated for Reach 2 during all three seepage runs was from the three subreaches between Dade City, Lacoochee, Trilby, and Ridge Manor (S) (sites R6-R9, fig. 15). Net seepage gains for the subreach between Dade City and Lacoochee (sites R6 and R7, fig. 15) ranged from $15 \mathrm{ft}^{3} / \mathrm{s}$ in April 2006 to $32 \mathrm{ft}^{3} / \mathrm{s}$ in April 2005 (table 7). This subreach most likely receives inflow from a spring that was discovered in April 2006 (Karst Underwater Research Inc., 2006), but was not measured during this study. Net seepage gains calculated for the 6.7-mi subreach between Lacoochee and Trilby (sites R7 and R8, fig. 15) ranged from $15 \mathrm{ft}^{3} / \mathrm{s}$ in April 2006 to $19 \mathrm{ft}^{3} / \mathrm{s}$ in May 2004, averaging about $17 \mathrm{ft}^{3} / \mathrm{s}$, or about $2.5 \mathrm{ft}^{3} / \mathrm{s} / \mathrm{mi}$ (tables $4-6$ ). Net seepage gains calculated for the 4.7-mi subreach between Trilby and Ridge Manor (S) (sites R8 and R9, fig. 15) ranged from $12 \mathrm{ft}^{3} / \mathrm{s}$ in April 2006 to $29 \mathrm{ft}^{3} / \mathrm{s}$ in April 2005, averaging about $21 \mathrm{ft}^{3} / \mathrm{s}$, or about $4.4 \mathrm{ft}^{3} / \mathrm{s} / \mathrm{mi}$ (tables $4-6$ ). The highest net seepage gain coincided with the highest flow in the river. This subreach received an average inflow of about $3.8 \mathrm{ft}^{3} / \mathrm{s}$ from Riverdale Spring based on the three seepage runs (site S30, fig. 15). Net seepage gain calculated for the 2.8-mi subreach between Ridge Manor (S) and Rital (sites R9 and R10, fig. 15) were considerably less than the other subreaches in Reach 2. Calculated gains ranged from $5.1 \mathrm{ft}^{3} / \mathrm{s}$ in April 2006 to $7.0 \mathrm{ft}^{3} / \mathrm{s}$ in April 2005, averaging about $6.0 \mathrm{ft}^{3} / \mathrm{s}$, or about $2.1 \mathrm{ft}^{3} / \mathrm{s} / \mathrm{mi}$ (tables 4-6). The highest net seepage gain in this subreach also coincided with the highest flow in the river.

\section{Reach 3}

Reach 3 is about $32.4 \mathrm{mi}$ long, extending from USGS gaging station 02312300 at Rital to USGS gaging station 02312720 at Wysong Dam (sites R10 and R17, fig. 15). 


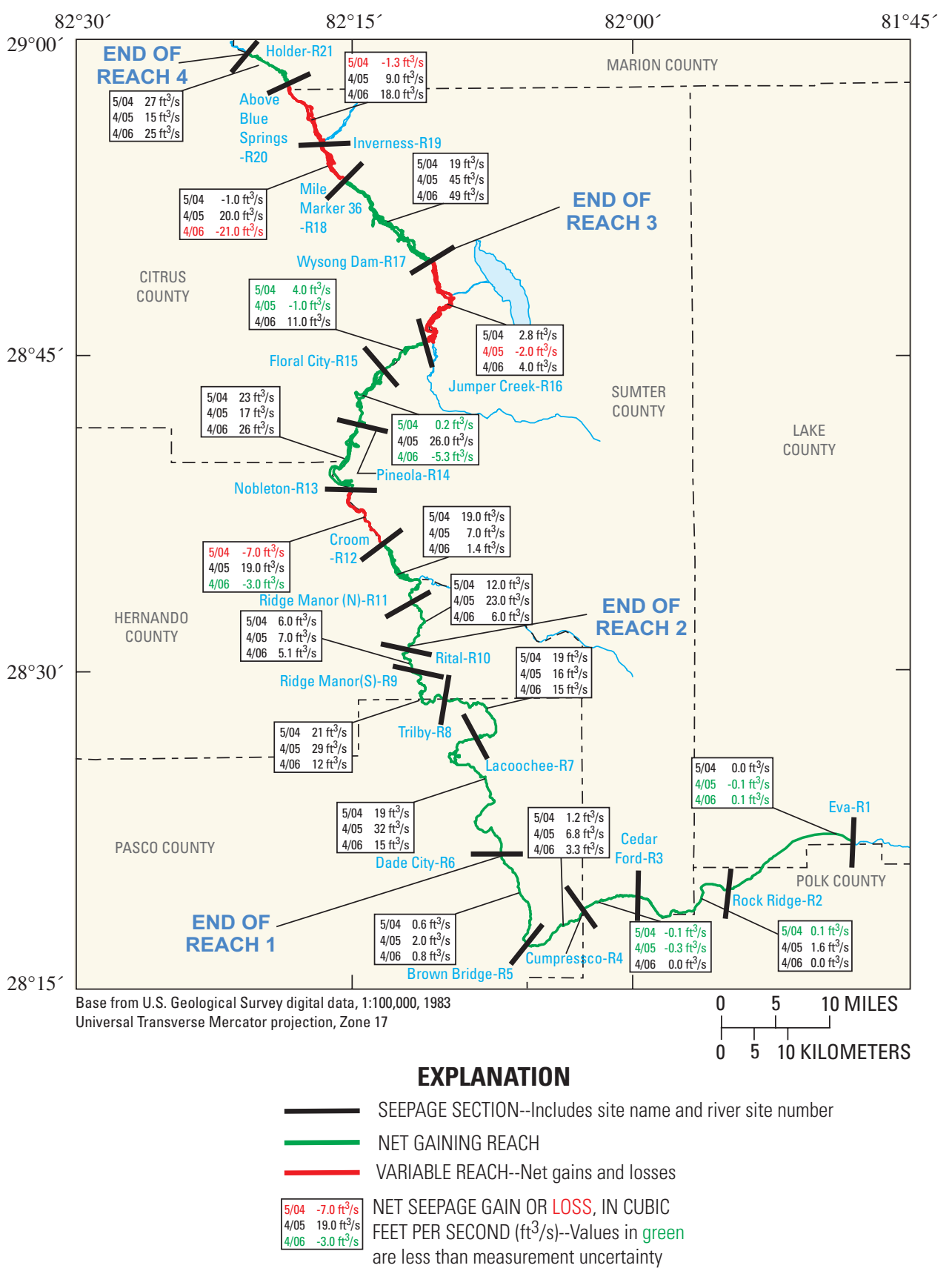

Figure 17. Generalized patterns of river and aquifer interaction, and net seepage gains and losses for each subreach along the Withlacoochee River. 
Measurements were made at five USGS gaging stations (sites R10, R12, R13, R15, and R17, fig. 15 and table 3), three ungaged sites (sites R11, R14, and R16, fig. 15 and table 3), four tributaries (sites T26, T27, T28, and T29, fig. 15 and table 3), and one spring (site S31, fig. 15 and table 3) during each of the seepage runs. Inflow from the tributaries averaged about $155 \mathrm{ft}^{3} / \mathrm{s}$ and was between 64 and 81 percent of the gains in this reach during seepage runs (tables 4-6). A net seepage gain was calculated for Reach 3 for all three seepage runs; however, small losses were calculated for two subreaches at least once. Losses also were calculated at two other subreaches, but these were less than the measurement uncertainty (fig. 17 and table 7). Groundwater seepage for Reach 3 averaged about $61 \mathrm{ft}^{3} / \mathrm{s}$ for the three seepage runs, which was about 13 percent of the average river flow at the Holder station (site R21, fig. 15). The largest gain calculated was about $89 \mathrm{ft}^{3} / \mathrm{s}$, or about $2.8 \mathrm{ft}^{3} / \mathrm{s} / \mathrm{mi}$, in April 2005. The smallest gain was about $40 \mathrm{ft}^{3} / \mathrm{s}$, or about $1.4 \mathrm{ft}^{3} / \mathrm{s} / \mathrm{mi}$ in April 2006 (tables 4-6). Varying releases of water from the Wysong Dam (site R17, fig. 15) in May 2004 and April 2006 were a potential source of error in the calculation of net seepage gains or losses in the subreaches adjacent to the dam. In order to reduce the effects of the variable releases, daily mean discharge for the Wysong Dam station was used for the May 2004 seepage run, and a 3-day mean discharge was used for the April 2006 seepage run.

Consistent net gains for all seepage runs were calculated for the 3.8-mi subreach between Rital and Ridge Manor (N) (sites R10 and R11, fig. 15). Gains ranged from $6.0 \mathrm{ft}^{3} / \mathrm{s}$ in April 2006 to $23 \mathrm{ft}^{3} / \mathrm{s}$ in April 2005, averaging about $13.7 \mathrm{ft}^{3} / \mathrm{s}$, or about $3.6 \mathrm{ft}^{3} / \mathrm{s} / \mathrm{mi}$ (fig. 17 and tables $4-6$ ). The highest gain coincided with the highest flow in the river. Consistent net gains for all seepage runs also were calculated for the 4.6-mi subreach between Ridge Manor (N) and Croom (sites R11 and R12, fig. 15). Groundwater seepage for this subreach ranged from about $1.4 \mathrm{ft}^{3} / \mathrm{s}$ in April 2006 to $19 \mathrm{ft}^{3} / \mathrm{s}$ in May 2004 (table 7 and fig. 17), averaging about $9.1 \mathrm{ft}^{3} / \mathrm{s}$, or about $2.0 \mathrm{ft}^{3} / \mathrm{s} / \mathrm{mi}$ (tables 4-6). Net seepage gains did not correlate with river discharge along this subreach, possibly due to the storage effects of Silver Lake, located about $1 \mathrm{mi}$ above Croom. The subreach between Ridge Manor (N) and Croom (sites R11 and R12, fig. 15) received inflow from the Little Withlacoochee River (site T26, fig. 15) that averaged about $11.3 \mathrm{ft}^{3} / \mathrm{s}$ for the three seepage runs.

Both gains and losses were calculated for the 5.2-mi subreach between Croom and Nobleton (sites R12 and R13, fig. 15) during the three seepage runs. A seepage loss of $7.0 \mathrm{ft}^{3} / \mathrm{s}$ was calculated for the May 2004 seepage run, whereas a seepage gain of $19 \mathrm{ft}^{3} / \mathrm{s}$ was calculated for the April 2005 seepage run. A seepage loss of $3.0 \mathrm{ft}^{3} / \mathrm{s}$ was calculated for the April 2006 seepage run; however, the gain was less than the accuracy of the measurement and was considered indeterminate (table 7). Net seepage gains/losses were positively correlated with river discharge, increasing with higher flows. Net gains were calculated for the 5.3-mi subreach between Nobleton and Pineola (sites R13 and R14, fig. 15) for all seepage runs. Groundwater seepage for this subreach ranged from about $17 \mathrm{ft}^{3} / \mathrm{s}$ in April 2005 to $26 \mathrm{ft}^{3} / \mathrm{s}$ in April 2006 (table 7, fig. 17), averaging about $22 \mathrm{ft}^{3} / \mathrm{s}$, or about $4.2 \mathrm{ft}^{3} / \mathrm{s} / \mathrm{mi}$ (tables 4-6). Net seepage gains in this subreach were inversely correlated with river discharge, increasing with decreasing river flows.

Both gains and losses also were calculated for the 4.7-mi subreach between Pineola and Floral City (sites R14 and R15, fig. 15), however, gains and losses for May 2004 and April 2005 were less than the measurement uncertainty (table 7). A seepage gain of $26 \mathrm{ft}^{3} / \mathrm{s}$ was calculated for April 2005 (table 7 and fig. 17); therefore, the subreach was considered a gaining subreach. The operation of control structures for the Lake Tsala Apopka Chain-of-Lakes is a source of uncertainty and may have affected the April 2005 seepage run results for this subreach. This subreach received an average of about $6 \mathrm{ft}^{3} / \mathrm{s}$ of inflow from Spring Run (site S31, fig. 15) during the seepage runs. Similar to the Pineola to Floral City subreach, both gains and losses were calculated for the 2.8-mi subreach between Floral City and Jumper Creek (sites R15 and R16, fig. 15). The seepage gain of $4.0 \mathrm{ft}^{3} / \mathrm{s}$ calculated for May 2004 and the seepage loss of $1.0 \mathrm{ft}^{3} / \mathrm{s}$ calculated for April 2005 were less than the measurement accuracy. The seepage gain of $11 \mathrm{ft}^{3} / \mathrm{s}$ calculated for April 2006 (table 7) was greater than measurement accuracy; therefore, the subreach was considered a gaining subreach. Net seepage in this subreach was inversely correlated with river discharge, increasing with decreasing river flows.

Seepage results for the 6.0-mi subreach between Jumper Creek and Wysong Dam (sites R16 and R17, fig. 15) were mixed during the three seepage runs. A net seepage gain of $2.8 \mathrm{ft}^{3} / \mathrm{s}$ in May 2004, a net seepage loss of $2.0 \mathrm{ft}^{3} / \mathrm{s}$ in April 2005, and a net seepage gain of $4.0 \mathrm{ft}^{3} / \mathrm{s}$ in April 2006 (table 7) were calculated for this subreach. All calculated gains and losses were greater than measurement accuracy, and the reach is shown as a variable reach in figure 17 . The highest seepage gain coincided with the lowest flow in the river and the seepage loss coincided with the highest flow in the river. Variable river flow due to the operation of Wysong Dam also may have affected the net seepage gain/loss calculations for this subreach during the May 2004 and April 2006 seepage runs. This subreach received inflow from Jumper Creek and Outlet River that averaged about $137 \mathrm{ft}^{3} / \mathrm{s}$, or about 29 percent of the average river flow at the Holder station (site 21, fig. 15). A surface-water outflow (loss) of $36 \mathrm{ft}^{3} / \mathrm{s}$ from the river to the Tsala Apopka Chain-of-Lakes was measured during the April 2005 seepage run.

\section{Reach 4}

Reach 4 is about $18 \mathrm{mi}$ long, extending from USGS gaging station 02312720 at Wysong Dam to USGS gaging station 02313000 near Holder (sites R17 and R21, fig. 15). Measurements were made at three USGS gaging stations (sites R17, R19, and R21, fig. 15 and table 3), two ungaged sites (sites R18, and R20, fig. 15 and table 3), and four springs 
(site S32-S35, fig. 15 and table 3) during each of the seepage runs. Inflow from these springs contributed about 60 to 88 percent of flow to this reach (tables 4-6). A net seepage gain was calculated for Reach 4 for all three seepage runs. Gains from groundwater averaged about $68 \mathrm{ft}^{3} / \mathrm{s}$, which was about 14.3 percent of the average river flow at the Holder station (site R21, fig. 15). The largest gain was about $89 \mathrm{ft}^{3} / \mathrm{s}$, or about $4.9 \mathrm{ft}^{3} / \mathrm{s} / \mathrm{mi}$, in April 2005. The smallest gain was about $44 \mathrm{ft}^{3} / \mathrm{s}$, or about $2.4 \mathrm{ft}^{3} / \mathrm{s} / \mathrm{mi}$, in May 2004. Most estimates for the subreaches in Reach 4 were net gains; however, the direction of exchange was mixed in two subreaches.

Net gains were calculated for all seepage runs for the 7.3-mi subreach between Wysong Dam and mile marker 36 (sites R17 and R18, fig. 15). Gains ranged from $19 \mathrm{ft}^{3} / \mathrm{s}$ in May 2004 to $49 \mathrm{ft}^{3} / \mathrm{s}$ in April 2006, averaging about $37.7 \mathrm{ft}^{3} / \mathrm{s}$, or about $5.1 \mathrm{ft}^{3} / \mathrm{s} / \mathrm{mi}$ (tables $4-7$ and fig. 17). This subreach received inflow from Nichols Spring, located about $1 \mathrm{mi}$ downstream of Wysong Dam, which averaged about $14 \mathrm{ft}^{3} / \mathrm{s}$, or about 3 percent of the river's volume. Seepage gains correlated with river discharge and generally increased with increasing river flows. Seepage calculated for the 2.1-mi subreach between mile marker 36 and Inverness (sites R18 and R19, fig. 15), however, was mixed. A net seepage gain of $20 \mathrm{ft}^{3} / \mathrm{s}$ in April 2005, and a net seepage loss of $21 \mathrm{ft}^{3} / \mathrm{s}$ in April 2006 (table 7) were calculated for this subreach. A net seepage loss of $1.0 \mathrm{ft}^{3} / \mathrm{s}$ calculated in May 2004 was less than the accuracy of the measurement and considered indeterminate. The net seepage gain coincided with the highest flow in the river, whereas the net seepage loss correlated with the lowest flow in the river. Similarly, both gains and losses were calculated for the 5.0-mi subreach between Inverness and Blue Spring (site R19 and R20, fig. 15). The subreach lost $1.3 \mathrm{ft}^{3} / \mathrm{s}$ in May 2004, but gained 9.0 and $18 \mathrm{ft}^{3} / \mathrm{s}$ in April 2005 and April 2006, respectively (table 7). Inflow from Gum Slough Springs (site S33, fig. 15) averaged about $88 \mathrm{ft}^{3} / \mathrm{s}$, or about 18.5 percent of the average river flow at the Holder station (site R21, fig. 15). Discharge from these springs contributed between 80 and 100 percent of gains calculated for this subreach during the seepage runs (tables 4-6). A relation between river flow and seepage rate was not apparent; however, during the May 2004 seepage run, seepage loss coincided with the lowest flow in the river.

Net gains were calculated for all seepage runs for the 3.6-mi subreach between Blue Spring and Holder (sites R20 and R21, fig. 15), and ranged from $15 \mathrm{ft}^{3} / \mathrm{s}$ in April 2005 to about $27 \mathrm{ft}^{3} / \mathrm{s}$ in May 2004, averaging about $22.3 \mathrm{ft}^{3} / \mathrm{s}$, or about $6.2 \mathrm{ft}^{3} / \mathrm{s} / \mathrm{mi}$ (tables 4-7 and fig. 17). This subreach received inflow from Blue Spring and Wilson Head Spring (sites S34 and S35, fig. 15), that averaged about $23.6 \mathrm{ft}^{3} / \mathrm{s}$, or about 4.9 percent of the average river flow at the Holder station (site R21, fig. 15). Discharge from these springs contributed about 41 and 70 percent of gains calculated for this subreach (tables 4-6). A relation between river flow and seepage rate was less clear for this subreach than for other subreaches where the river consistently gained water. Interestingly, the lowest net seepage gain in this subreach correlated with the highest river discharge.

\section{Water Chemistry}

Dry season and wet season samples were collected in March and October 2004 to characterize the water quality in the Withlacoochee River watershed and to evaluate the spatial and temporal factors influencing streamflow, such as groundwater discharge and runoff. Isotopic data also were used to gain insight into the groundwater flow system. These data have been published in the annual Water-Data Reports for the year the samples were collected, and are stored in the USGS NWIS database. Data can be accessed from the Internet at http://waterdata.usgs.gov/nwis.

Sources of water to the Withlacoochee River include springs, tributaries, and the surficial and Upper Floridan aquifers, and all affect the water chemistry of the river. Water in the upper reaches of the Withlacoochee River originates mostly from rainfall, flowing to the river through tributary streams and as water seeping from the surficial aquifer. In the middle and lower reaches, water in the river is primarily from springs and groundwater seepage from the Upper Floridan aquifer.

Water in samples collected from the upper reaches of the Withlacoochee River was slightly acidic as the river emerged from its headwaters in the Green Swamp. At the Cumpressco station (site $\mathrm{SW} 2$, fig. 2), measured $\mathrm{pH}$ values averaged about 6.2 (table 8). Calcium, magnesium, sulfate, alkalinity, and strontium concentrations and specific conductance were less than at downstream sites (fig. 18). Chloride, sodium, potassium, and organic carbon concentrations were greater than at downstream sites. Increases in $\mathrm{pH}$ and specific conductance, alkalinity, calcium, magnesium, sulfate, and strontium concentrations and decreases in chloride, sodium, potassium, and dissolved organic carbon concentrations indicate increasing influence from groundwater on the river chemistry and a decreasing influence from surface-water sources in the downstream direction. Chloride, sodium, potassium and dissolved organic carbon concentrations at the Holder station (site SW13, fig. 2) were 40 to 80 percent lower than concentrations at the Cumpressco station. Increasing contribution of groundwater to the river also is indicated by the increasing specific conductance values measured at downstream stations. For example, specific conductance measured at the Cumpressco station in 2004 was $99 \mu \mathrm{S} / \mathrm{cm}$, and increased to $315 \mu \mathrm{S} / \mathrm{cm}$ at the Holder station (table 8). Increases in specific conductance were observed in the downstream direction along tributaries, indicating groundwater seepage also contributes to these streams.

The effect of increasing groundwater discharge in the downstream direction on the chemistry of water in the Withlacoochee River is shown in figure 19. Water types are described by the relative percentage of cations and anions (Hem, 1985). The chemical composition of river water in the downstream direction has a linear trend suggesting a simple mixing model (fig. 19). Near the headwaters of the river, the water is dominated by sodium, calcium, and chloride ions (Na-Ca-Cl), resulting in a $\mathrm{Na}-\mathrm{Ca}-\mathrm{Cl}$ water type. The source of the sodium and chloride ions may be the accumulation of marine aerosols 


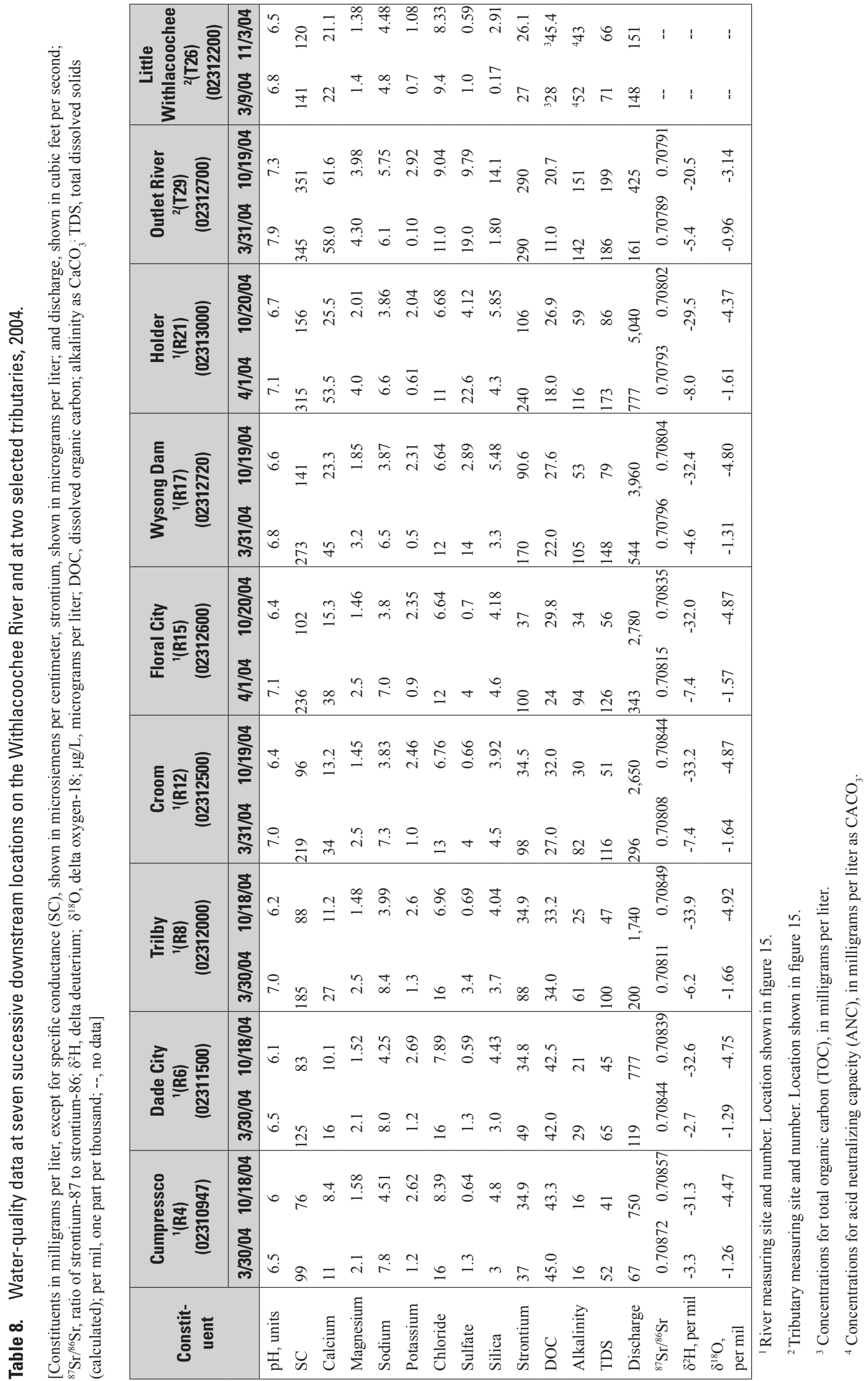



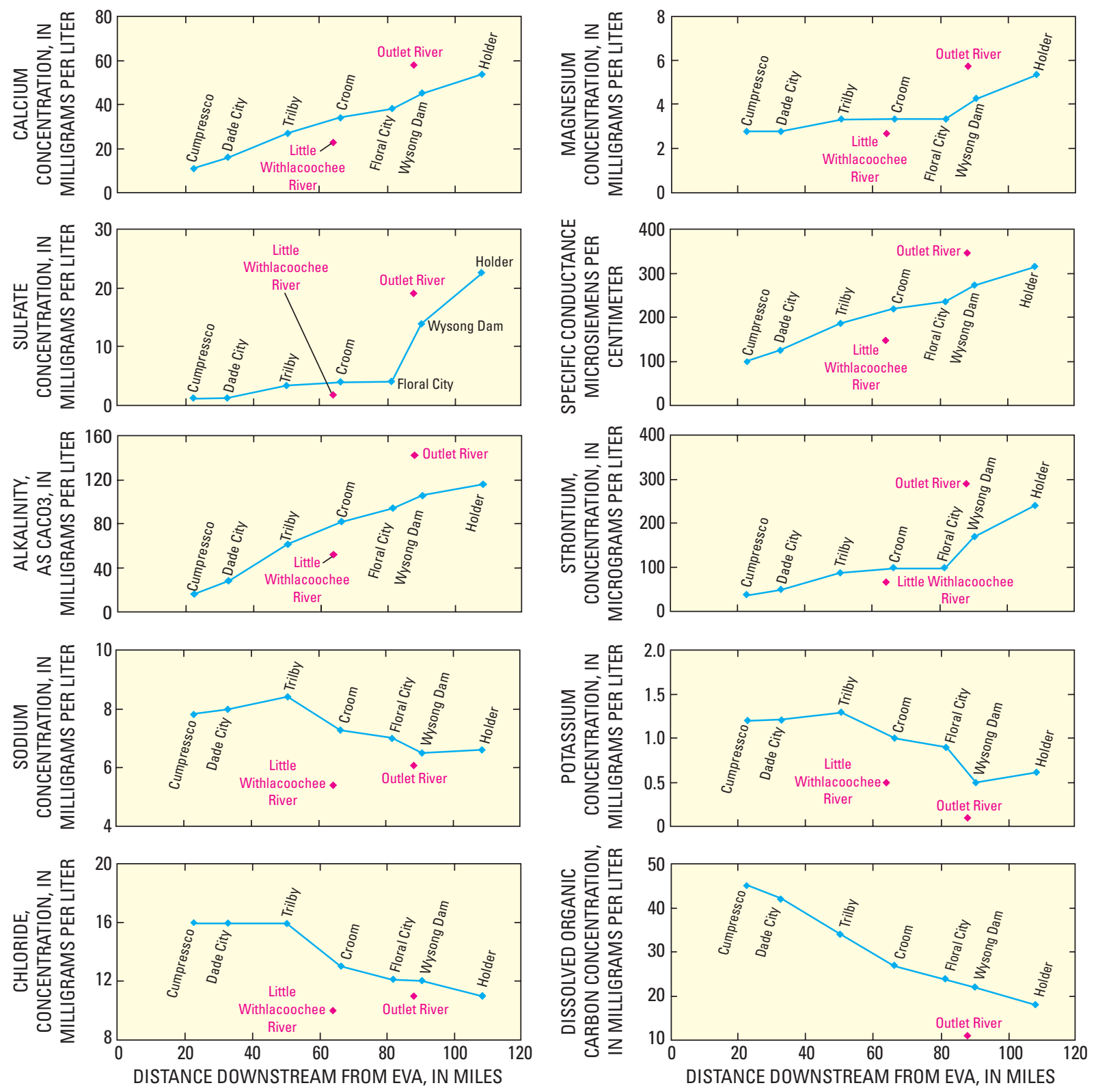

Figure 18. Downstream change in water chemistry along the Withlacoochee River during dry conditions, March 2004 


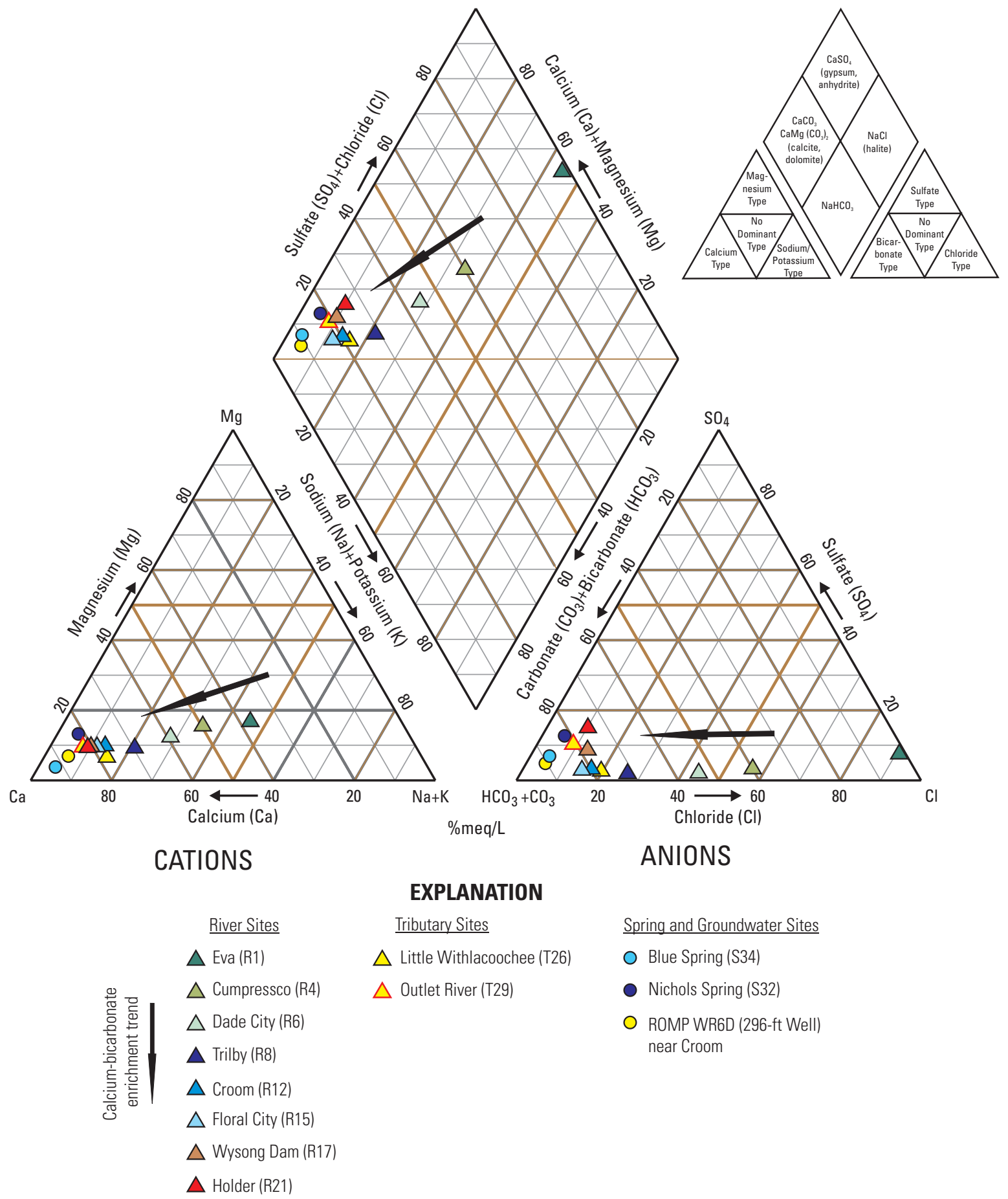

Figure 19. Water chemistry at eight river sites, two tributary sites, two springs, and one Upper Floridan aquifer groundwater reference site in the Withlacoochee River watershed during low flow conditions in 2004. At Eva, the mean concentration is shown for the years 1956-93. Location of river, tributary, and spring sites shown in figure 15. 
Table 9. Water-quality data for groundwater sites.

[Concentrations in milligrams per liter, except for specific conductance, shown in microsiemens per centimeter, and strontium, shown in micrograms per liter; alkalinity as $\mathrm{CaCO}_{3} ;{ }^{87} \mathrm{Sr} /{ }^{86} \mathrm{Sr}$, ratio of strontium-87to strontium-86; $\delta^{2} \mathrm{H}$, delta deuterium; $\delta^{18} \mathrm{O}$, delta oxygen-18; per mil, one part per thousand;--, no data]

\begin{tabular}{|c|c|c|c|c|c|}
\hline $\begin{array}{l}\text { Property or } \\
\text { constituent }\end{array}$ & $\begin{array}{c}\text { Nichols Spring } \\
\text { (S32) }^{1} \\
(285022082121000) \\
3 / 11 / 04\end{array}$ & $\begin{array}{c}\text { Blue Spring } \\
\text { (S34) }^{1} \\
(285809082185200) \\
3 / 11 / 04\end{array}$ & $\begin{array}{c}\text { Wysong Dam } \\
\text { (GW17) }^{2} \\
\text { 89-ft well } \\
\text { (284924082105501) } \\
12 / 15 / 04\end{array}$ & $\begin{array}{c}\text { Wysong Dam } \\
\text { (GW17)² } \\
\text { 13-ft well } \\
\text { (284924082105502) } \\
12 / 15 / 04\end{array}$ & $\begin{array}{c}\text { ROMP WR6D } \\
\text { (GW11) } \\
296-f t \text { well } \\
(283623082132601) \\
12 / 14 / 04\end{array}$ \\
\hline $\mathrm{pH}$, units & 7.3 & 7.4 & 7.2 & 7.3 & 7.4 \\
\hline Specific conductance & 375 & 335 & 411 & 459 & 383 \\
\hline Calcium & 63 & 62 & 79 & 102 & 75 \\
\hline Magnesium & 5.9 & 2.3 & 4.6 & 0.96 & 4.5 \\
\hline Sodium & 4.6 & 3.0 & 6.2 & 1.5 & 4.2 \\
\hline Potassium & 0.40 & 0.20 & 0.48 & 3.9 & 0.30 \\
\hline Chloride & 8.1 & 5.5 & 11 & 1.7 & 6.6 \\
\hline Sulfate & 25 & 11 & 9.5 & 11 & 1.1 \\
\hline Silica & 8.3 & 5.9 & 9.2 & 7.1 & 8.3 \\
\hline Strontium & 270 & 130 & 212 & 196 & 136 \\
\hline $\begin{array}{l}\text { Dissolved organic } \\
\text { carbon }\end{array}$ & 2.5 & 0.60 & 2.9 & 1.7 & 1.2 \\
\hline Alkalinity & 160 & 155 & 194 & 238 & 198 \\
\hline Total dissolved solids ${ }^{3}$ & -- & -- & 236 & 275 & 219 \\
\hline${ }^{87} \mathrm{Sr} /{ }^{86} \mathrm{Sr}$ & 0.70787 & 0.70795 & -- & -- & -- \\
\hline$\delta^{2} \mathrm{H}$, per mil & -16.6 & -19.1 & -- & -- & -- \\
\hline$\delta^{18} \mathrm{O}$, per mil & -3.28 & -3.72 & -- & -- & -- \\
\hline
\end{tabular}

${ }^{1}$ Spring sites shown in figure 15 and described in table 3.

${ }^{2}$ Well sites shown in figure 7 and described in table 2.

${ }^{3}$ Calculated value of total dissolved solids.

entrained in rainfall or deposition by wind in the upper reaches of the watershed (Hem, 1985). Agricultural fertilizers and other human activities also may contribute to the accumulation of sodium and chloride in the headwater areas. The low $\mathrm{pH}$, low dissolved solids, and relatively high concentrations of organic carbon in the river water indicate substantial contributions of water originating in wetlands and swamps. Farther downstream, calcium and bicarbonate $\left(\mathrm{Ca}-\mathrm{HCO}_{3}\right)$ were the dominant ions in the river water, resulting in a $\mathrm{Ca}-\mathrm{HCO}_{3}$ water type similar to groundwater. The change in river water from a Na-Ca-Cl to a $\mathrm{Ca}-\mathrm{HCO}_{3}$ water type indicates the increasing influence of groundwater from the Upper Floridan aquifer. Downstream from Dade City, the similarity of samples from the river and groundwater is shown in figure 19. Water-quality data collected during this study from springs and groundwater sites within the watershed are presented in table 9 for comparison. River water samples collected between the Dade City and Holder stations generally were of the same ionic composition as groundwater: predominately calcium bicarbonate, varying only in ionic strength. While groundwater and river water were similar during low flow conditions, river-water chemistry was more variable during high flow conditions because of dilution by storm runoff. The variability in constituent concentrations is greater in the upper reach of the river than in the middle and lower reaches because of the greater influence of surface runoff.

Strontium concentrations in surface water are directly correlated to groundwater inflow and are inversely correlated to streamflow. Strontium concentrations in water increase as carbonate rock containing strontium dissolves. Because groundwater is in contact with aquifer material for a relatively long time compared to river water, concentrations in groundwater are usually greater than in river water. During low-flow conditions, strontium concentrations increased in the Withlacoochee River in a downstream direction, ranging from $37 \mu \mathrm{g} / \mathrm{L}$ at the Cumpressco station to $240 \mu \mathrm{g} / \mathrm{L}$ at the Holder station (table 8), further indicating that groundwater was a major source of inflow to the river. 


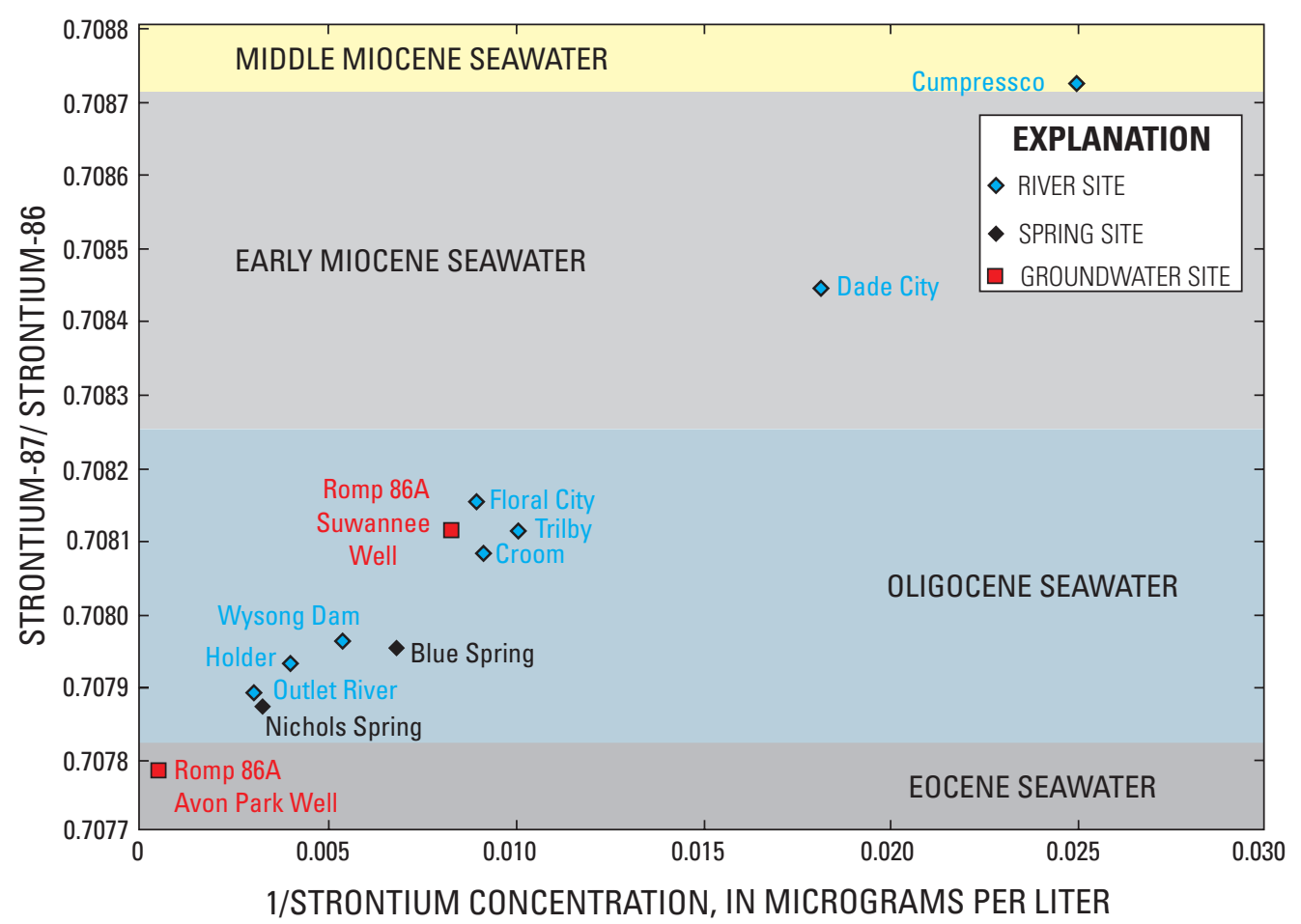

Figure 20. Relation between the ratio of strontium- 87 to strontium- 86 and the inverse of the concentration of strontium in samples from the Withlacoochee River sites, springs, and groundwater reference wells. Seawater boundaries are from Howarth and McArthur (1997).

The strontium isotope ratio $\left({ }^{87} \mathrm{Sr} /{ }^{86} \mathrm{Sr}\right)$ can be used to indicate the age of the rock that the groundwater has been in contact with because ${ }^{87} \mathrm{Sr} /{ }^{86} \mathrm{Sr}$ ratios varied in seawater during the time the rocks in the study area were deposited (DePaolo and Ingram, 1985; Hess and others, 1986; Howarth and McArthur, 1997; Kendall, 1998). Therefore, waters that have geochemically evolved in marine deposits of differing age will have differing ${ }^{87} \mathrm{Sr} /{ }^{86} \mathrm{Sr}$ ratios, and the ratio increases as the age decreases. Water from shallow parts of the aquifer system has higher ${ }^{87} \mathrm{Sr}{ }^{86} \mathrm{Sr}$ ratios compared to water from deeper parts of the aquifer system. In the Withlacoochee River watershed, ${ }^{87} \mathrm{Sr} /{ }^{86} \mathrm{Sr}$ ratios in river water decreased from 0.70872 to 0.70793 in the downstream direction (table 8), indicating that the source of the groundwater flowing to the river was from older deposits farther downstream. The ${ }^{87} \mathrm{Sr} /{ }^{86} \mathrm{Sr}$ ratios were plotted against the inverse of strontium concentration in figure 20 , so that resulting values would plot along a straight line. The ${ }^{87} \mathrm{Sr}{ }^{86} \mathrm{Sr}$ ratios of samples collected during a previous study from wells completed into the Suwannee Limestone of Oligocene age and the Avon Park Formation of Eocene age at the ROMP 86A site near Zephyrhills were included to compare with ratios from the surface-water and spring sites (Trommer and others, 2007). At the Dade City and Cumpressco gaging stations, ${ }^{87} \mathrm{Sr} /{ }^{86} \mathrm{Sr}$ ratios indicated that the water in the river had been in contact with deposits of Miocene age (fig. 20 and table 8). Deposits of Miocene age are almost non-existent along the river channel and are absent in upgradient parts of the aquifer near these stations. Water from the upgradient, near-surface Cypresshead Formation of Pliocene age (figs. 5 and 6) is most likely mixing with water from the deeper Ocala Limestone of Eocene age, resulting in ${ }^{87} \mathrm{Sr} /{ }^{86} \mathrm{Sr}$ ratios that are similar to ${ }^{87} \mathrm{Sr} /{ }^{86} \mathrm{Sr}$ ratios of deposits of Miocene age. The ${ }^{87} \mathrm{Sr} /{ }^{86} \mathrm{Sr}$ ratios in samples from the Trilby, Croom, and Floral City gaging stations were similar to the ratio from the Suwannee Limestone ROMP 86A well, indicating the source of the river water was from the Suwannee Limestone of Oligocene age; however, these deposits also are absent along the river channel and in upgradient parts of the aquifer near these stations. The observed ${ }^{87} \mathrm{Sr} /{ }^{86} \mathrm{Sr}$ ratios, indicating water from deposits of Oligocene age, most likely result from 
Table 10. Mean concentration of selected water-quality constituents at eight Withlacoochee River gaging stations for the period of record.

[Conc., concentration in milligrams per liter, except for specific conductance (SC), shown in microsiemens per centimeter, and iron and strontium, shown in micrograms per liter; $\mathrm{n}$, number of samples; TOC, total organic carbon; TDS, total dissolved solids]

\begin{tabular}{|c|c|c|c|c|c|c|c|c|c|c|c|c|c|c|c|c|}
\hline $\begin{array}{l}\text { Property or } \\
\text { constituent }\end{array}$ & \multicolumn{2}{|c|}{$\begin{array}{c}\text { Eva }^{1} \\
\text { (SW1) } \\
(02310800)\end{array}$} & \multicolumn{2}{|c|}{$\begin{array}{c}\text { Cumpressco } \\
\text { (SW2) } \\
\text { (02310947) }\end{array}$} & \multicolumn{2}{|c|}{$\begin{array}{c}\text { Dade City } \\
\text { (SW3) } \\
(02311500)\end{array}$} & \multicolumn{2}{|c|}{$\begin{array}{c}\text { Trilby } \\
\text { (SW4) } \\
(02312000)\end{array}$} & \multicolumn{2}{|c|}{$\begin{array}{c}\text { Croom } \\
\text { (SW7) } \\
(02312500)\end{array}$} & \multicolumn{2}{|c|}{$\begin{array}{l}\text { Floral City } \\
\text { (SW9) } \\
(02312600)\end{array}$} & \multicolumn{2}{|c|}{$\begin{array}{c}\text { Wysong Dam } \\
\text { (SW11) } \\
(02312720)\end{array}$} & \multicolumn{2}{|c|}{$\begin{array}{c}\text { Holder } \\
\text { (SW13) } \\
(02313000)\end{array}$} \\
\hline $\mathrm{pH}$, units & 4.9 & 227 & 6.4 & 257 & 6.6 & 173 & 6.9 & 137 & 7.1 & 172 & 7.2 & 154 & 7.2 & 106 & 7.5 & 384 \\
\hline $\mathrm{SC}, \mu \mathrm{S} / \mathrm{cm}$ & 86 & 253 & 148 & 330 & 175 & 212 & 245 & 214 & 230 & 251 & 233 & 241 & 280 & 178 & 280 & 419 \\
\hline Sodium & 7.0 & 82 & 8.1 & 29 & 7.2 & 83 & 6.6 & 19 & 6.3 & 143 & 6.6 & 126 & 5.6 & 8 & 5.1 & 297 \\
\hline Potassium & 0.70 & 82 & 1.2 & 29 & 0.70 & 83 & 0.70 & 19 & 1.0 & 143 & 1.0 & 126 & 0.60 & 8 & 0.50 & 295 \\
\hline Chloride & 13 & 81 & 16 & 29 & 14 & 82 & 10 & 19 & 11 & 144 & 11 & 126 & 9.2 & 8 & 9.1 & 347 \\
\hline Sulfate & 4.2 & 81 & 4.6 & 28 & 2.7 & 82 & 5.8 & 19 & 6.4 & 143 & 11 & 124 & 17 & 8 & 27 & 317 \\
\hline TDS & 116 & 75 & 163 & 26 & 137 & 78 & 143 & 15 & 168 & 138 & 175 & 138 & 173 & 5 & 187 & 291 \\
\hline $\begin{array}{r}\text { Period of } \\
\text { record }\end{array}$ & \multicolumn{2}{|c|}{$1956-1983$} & \multicolumn{2}{|c|}{ 1961-2007 } & \multicolumn{2}{|c|}{ 1958-2004 } & \multicolumn{2}{|c|}{ 1956-2007 } & \multicolumn{2}{|c|}{ 1956-2007 } & \multicolumn{2}{|c|}{ 1966-2007 } & \multicolumn{2}{|c|}{ 1966-2007 } & \multicolumn{2}{|c|}{ 1950-2007 } \\
\hline
\end{tabular}

${ }^{1}$ Surface-water sites shown in figure 2 and described in table 1.

the mixing of water from deposits of Pliocene and Eocene age. A larger amount of water from deposits of Eocene age appears to be present in samples from these stations than from samples at the upstream Dade City and Cumpressco stations. The ${ }^{87} \mathrm{Sr} /{ }^{86} \mathrm{Sr}$ ratios from the Holder, Wysong Dam, and Outlet River sites and Nichols and Blue Springs plotted between the ${ }^{87} \mathrm{Sr} /{ }^{86} \mathrm{Sr}$ ratios from the ROMP 86A Suwannee and Avon Park wells (fig. 20). The source of the water also appears to be from deposits of Oligocene age that are deeper and older than at the upstream stations; however these deposits also are absent in the river channel or aquifer in this area. Mixing of water from deposits of Pliocene and Eocene age also are the most likely source of water in the river at these stations. Most of the water appears to be from deposits of Eocene age.

Cation and anion concentrations in water samples collected from the Withlacoochee River during this study were more dilute than the mean concentrations of samples for the period of record. The dilution was probably the result of greater surface runoff and/or higher than normal shallow groundwater contributions to the river from the surficial aquifer, which has low concentrations of ions. Cation concentrations during this study were about 30 percent lower than the mean cation concentrations of historical data. Anion concentrations during this study were between 20 and 32 percent lower than historical data. Table 10 provides the mean concentration of selected constituents for the period of record for eight Withlacoochee River gaging stations.

\section{Hydrograph Separation}

Base flow is that part of streamflow usually attributed to groundwater discharge (U.S. Geological Survey, 1989). The standard assumptions are that base flow equals groundwater discharge, and that groundwater discharge is about equal to groundwater recharge over the watershed. During periods of little or no rainfall, streamflow is assumed to be composed entirely of groundwater (base flow), allowing the amount of streamflow contributed by groundwater to be estimated. According to Kinzelbach and others (2002), recharge estimates using hydrograph separation may be accurate within a factor of 2 , and this can be one of the best methods for estimating long-term average regional recharge. However, two basin characteristics can affect the accuracy of the base-flow estimates: relatively low topographic relief and potentially slow drainage of surface water from wetlands (Halford and Mayer, 2000). Both of these basin characteristics exist in the Withlacoochee River watershed. Hydrograph separation base-flow estimates using the standard assumptions tend to overestimate groundwater discharge to rivers in west-central Florida (Halford and Mayer, 2000).

A conductivity mass-balance (CMB) method developed by Stewart and others (2007) was used to calibrate the hydrograph separation method in this study to increase accuracy. The CMB method was applied to approximately 2 years of continuous streamflow and conductivity data collected during the study to calculate base flow. The hydrograph separation 
method was then calibrated to the CMB method by varying the time parameter. A spreadsheet, rather than the USGS HYSEP computer program, was used so the time could be varied easily (Stewart and others, 2007). The sliding interval solution to the hydrograph separation method provided the "best fit" calibration. Base flow was then calculated for the 1983-2006 period using the calibrated hydrograph separation method. Figure 21 shows cumulative base flow hydrographs from the three uncalibrated hydrograph separation methods, the CMB method, and the calibrated hydrograph separation method.

Base flow was estimated for the Withlacoochee River at the Cumpressco, Dade City, Croom, and Holder gaging stations. Mean annual base flow calculated using the standard procedures recommended in the HYSEP program (Sloto and Crouse, 1996) for each of these stations was $35,238,47,688$, 109,748 , and $251,940 \mathrm{ft}^{3} / \mathrm{s}$, or 4.7, 4.6, 5.0, and $5.1 \mathrm{in} / \mathrm{yr}$ over the individual drainage areas, respectively. Mean annual streamflow for these stations was 48,046, 62,628, 124,887, and $274,266 \mathrm{ft}^{3} / \mathrm{s}$, or $6.4,6.0,5.7$, and $5.6 \mathrm{in} / \mathrm{yr}$, respectively (table 11). The percentage of mean annual streamflow that was estimated as base flow (the base-flow index) ranged from 73 to 92 percent. The low topographic relief and presence of large wetland areas affect the accuracy of these estimates, and base flow appears to be overestimated using the standard procedures of the HYSEP program. When the hydrograph separation method was calibrated using available specific conductance data (about 2 years), mean annual base-flow estimates were considerably lower. Estimates were 5,005, 13,648, 32,905 , and $130,349 \mathrm{ft}^{3} / \mathrm{s}$, or $0.6,1.3,1.5$, and $2.7 \mathrm{in} / \mathrm{yr}$ for the Cumpressco, Dade City, Croom, and Holder stations, respectively. Corresponding base-flow indexes were 1.04, 21.8, 26.3 , and 47.5 percent, respectively (table 11 ). The increasing base-flow index in the downstream direction provides further evidence of increasing groundwater discharge to the river.

\section{Groundwater Levels and Flow Direction}

Five of the paired or nested well sites (sites GW1, GW6, GW12, GW17, and GW18) and the ROMP WR6 Withlacoochee Transect wells (sites GW8-11) shown in figure 7 and described in table 2 are located near the Withlacoochee River and were used to evaluate groundwater flow near the river channel. Single Upper Floridan aquifer wells located near the Dade City and Floral City gaging stations (sites SW3 and SW9, fig. 2) were included in this analysis. All wells and gaging stations were leveled to NGVD 29. Hydrographs of groundwater levels and river stage constructed from measurements made during the study period (October 2003 to September 2006) were compared to determine potential flow direction. A hydrogeologic cross section also was constructed for the ROMP WR6 Withlacoochee River well transect (fig. 22).

The Cumpressco well site (site GW1, fig. 7) is located near the Cumpressco gaging station (site SW2, fig. 2). River stage was consistently below groundwater heads in both the shallow and deep Upper Floridan aquifer at this site.
Water-level altitudes in the deep Upper Floridan aquifer well were consistently higher than in the shallow Upper Floridan aquifer well, indicating upward potential for flow to the shallower deposits and discharge to the river. Conditions were similar for the single Upper Floridan aquifer well located near the Dade City gaging station (site SW3, fig. 2); river stage was consistently lower than groundwater heads in the Upper Floridan aquifer, indicating potential discharge to the river.

Water-level altitudes in the shallow Upper Floridan aquifer well were higher than in the deeper Upper Floridan aquifer well at the Peterson Park well site (site GW6, fig. 7) located near the Trilby gaging station (site GW4, fig. 2). River stage at the Trilby station was below groundwater heads except during wet conditions when river stage was higher. The potential for both recharge and discharge, primarily between the shallower deposits within the Upper Floridan aquifer and the river, exists at this site. Similarly, there was an upward gradient in the Upper Floridan aquifer at the Canoe Outpost wells (site GW12, fig. 7) located near the Nobleton gaging station (site SW8, fig. 2) except during wet periods. Groundwater discharged to the river during most of the study period. Potential for the river to recharge the aquifer exists only during high streamflow events. Conditions also were similar for the single Upper Floridan aquifer well located near the Floral City gaging station (site SW9, fig. 2). River stage was generally lower than groundwater heads in the Upper Floridan aquifer at this site except during periods of high streamflow, indicating long periods of groundwater discharge to the river and shorter periods of recharge to the aquifer from the river.

Upward head gradients were consistently observed in the surficial and Upper Floridan aquifers at the well site (site GW17, fig. 7) located at the Wysong Dam gaging station (site SW11, fig. 2), and in the Upper Floridan aquifer at the Potts Preserve well site (site GW18, fig. 7) near the Inverness gaging station (site SW12, fig. 2). The potential for aquifer discharge to the river at these sites was consistent throughout the study period.

The ROMP WR6 Withlacoochee River transect is located near the USGS gaging station at Croom (SW7, fig. 2). The well transect consists of four nested sites. A surficial aquifer well and shallow and deep Upper Floridan aquifer wells are located at each site. Well sites WR6A and WR6B are on the west side of the river and sites WR6C and WR6D are on the east side (fig. 22). During wet conditions, river stage was lower than groundwater heads, and head gradients in the Upper Floridan aquifer were toward the river. This pattern is consistent with groundwater discharge (fig. 22A). During dry conditions, water levels in the Upper Floridan aquifer wells at the western WR6A and WR6B Upper Floridan aquifer wells were lower than river stage, indicating potential recharge to the aquifer. However, upward head gradients existed in the Upper Floridan aquifer at WR6C and WR6D Upper Floridan aquifer wells on the east side of the river, indicating discharge to the river from this side. The Withlacoochee River may receive groundwater inflow from the east and lose water to the underlying aquifer to the west (fig. 22B) in this area during dry conditions. 

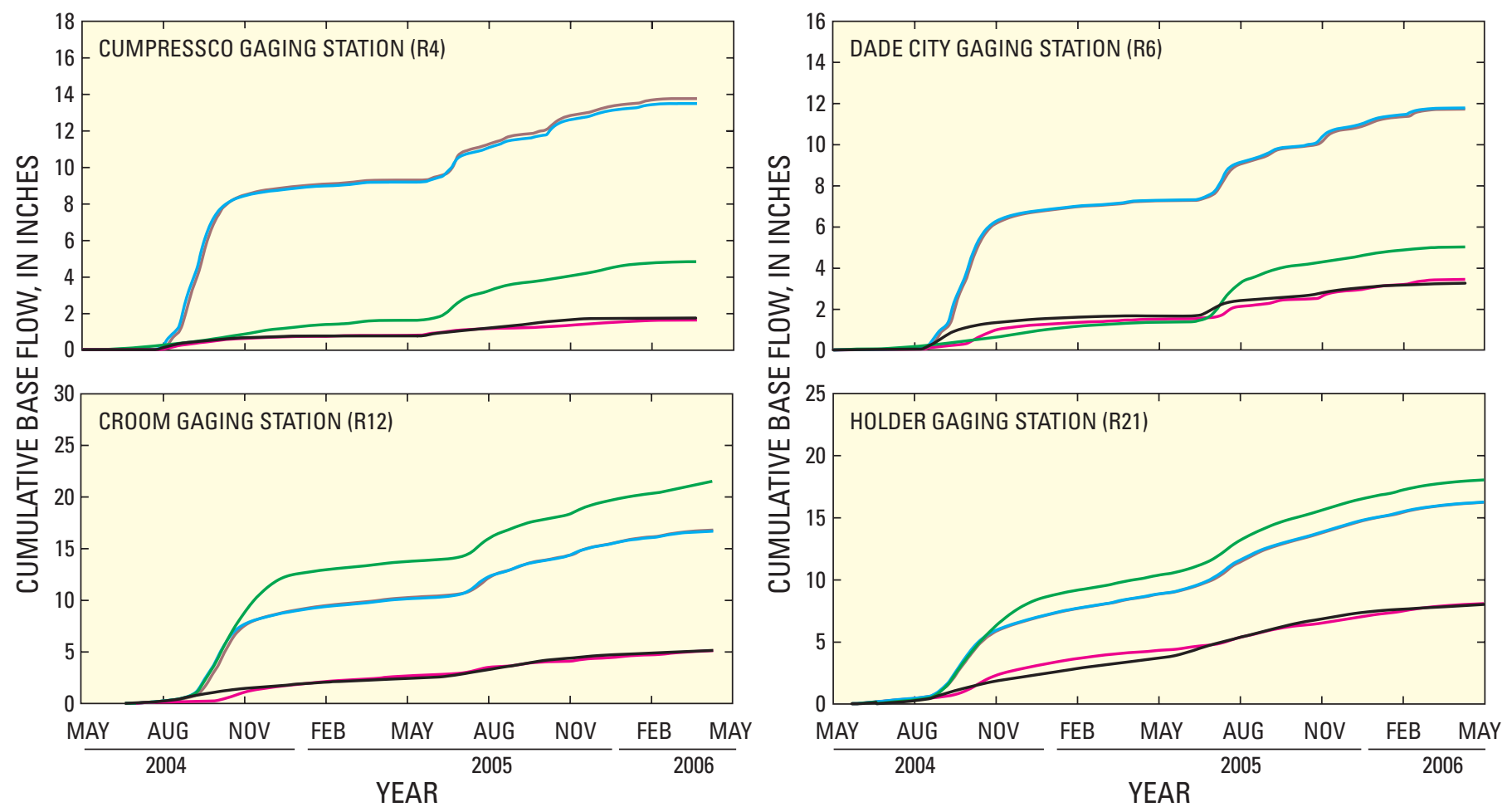

\section{EXPLANATION}

CONDUCTIVITY MASS-BALANCE METHOD

HYDROGRAPH SEPARATION - FIXED INTERNAL METHOD

HYDROGRAPH SEPARATION - SLIDING INTERNAL METHOD

— HYDROGRAPH SEPARATION - LOCAL MINIMUM METHOD

— CALIBRATED HYDROGRAPH SEPARATION METHOD

Figure 21. Base flow calculated using the hydrograph separation (HYSEP) method with the fixed interval, sliding interval, and local minimum solutions; the conductivity mass-balance method; and the calibrated HYSEP method at the Cumpressco, Dade City, Croom, and Holder gaging stations. Station locations are shown in figure 15.

Table 11. Base flow estimated by hydrograph separation methods for 1983-2006

$\left[\mathrm{mi}^{2}\right.$, square mile; $\mathrm{ft}^{3} / \mathrm{s}$, cubic feet per second; in/yr, inches per year]

\begin{tabular}{|c|c|c|c|c|c|c|c|c|c|c|}
\hline \multirow{2}{*}{$\begin{array}{c}\text { Map } \\
\text { number } \\
\text { (fig. 15) }\end{array}$} & \multirow[t]{2}{*}{ Station description } & \multirow{2}{*}{$\begin{array}{c}\text { USGS } \\
\text { identification } \\
\text { number }\end{array}$} & \multirow{2}{*}{$\begin{array}{c}\text { Drainage } \\
\text { area } \\
\left(\mathrm{mi}^{2}\right)\end{array}$} & \multicolumn{2}{|c|}{$\begin{array}{l}\text { Mean annual } \\
\text { streamflow }\end{array}$} & \multicolumn{2}{|c|}{$\begin{array}{c}\text { Uncalibrated } \\
\text { mean annual } \\
\text { base flow }\end{array}$} & \multicolumn{2}{|c|}{$\begin{array}{l}\text { Calibrated mean } \\
\text { annual base flow }\end{array}$} & \multirow{2}{*}{$\begin{array}{l}\text { Calibrated } \\
\text { base flow } \\
\text { index } \\
\text { (percent) }\end{array}$} \\
\hline & & & & $\mathrm{ft}^{3} / \mathrm{s}$ & in/yr & $\mathrm{ft}^{3} / \mathrm{s}$ & in/yr & $\mathrm{ft}^{3} / \mathrm{s}$ & in/yr & \\
\hline R4 & Withlaco & 02 & 280 & 48,046 & 6.4 & 35,238 & 4.7 & 5,005 & 0.6 & 1.04 \\
\hline R6 & Withlacoochee River near Dade City & 02311500 & 390 & 62,628 & 6.0 & 47,688 & 4.6 & 13,648 & 1.3 & 21.8 \\
\hline R12 & Withlacoochee River at Croom & 02312500 & 810 & 124,887 & 5.7 & 109,748 & 5.0 & 32,905 & 1.5 & 26.3 \\
\hline R21 & Withlacoochee River near Holder & 02313000 & 1,825 & 274,266 & 5.6 & 251,940 & 5.1 & 130,349 & 2.7 & 47.5 \\
\hline
\end{tabular}



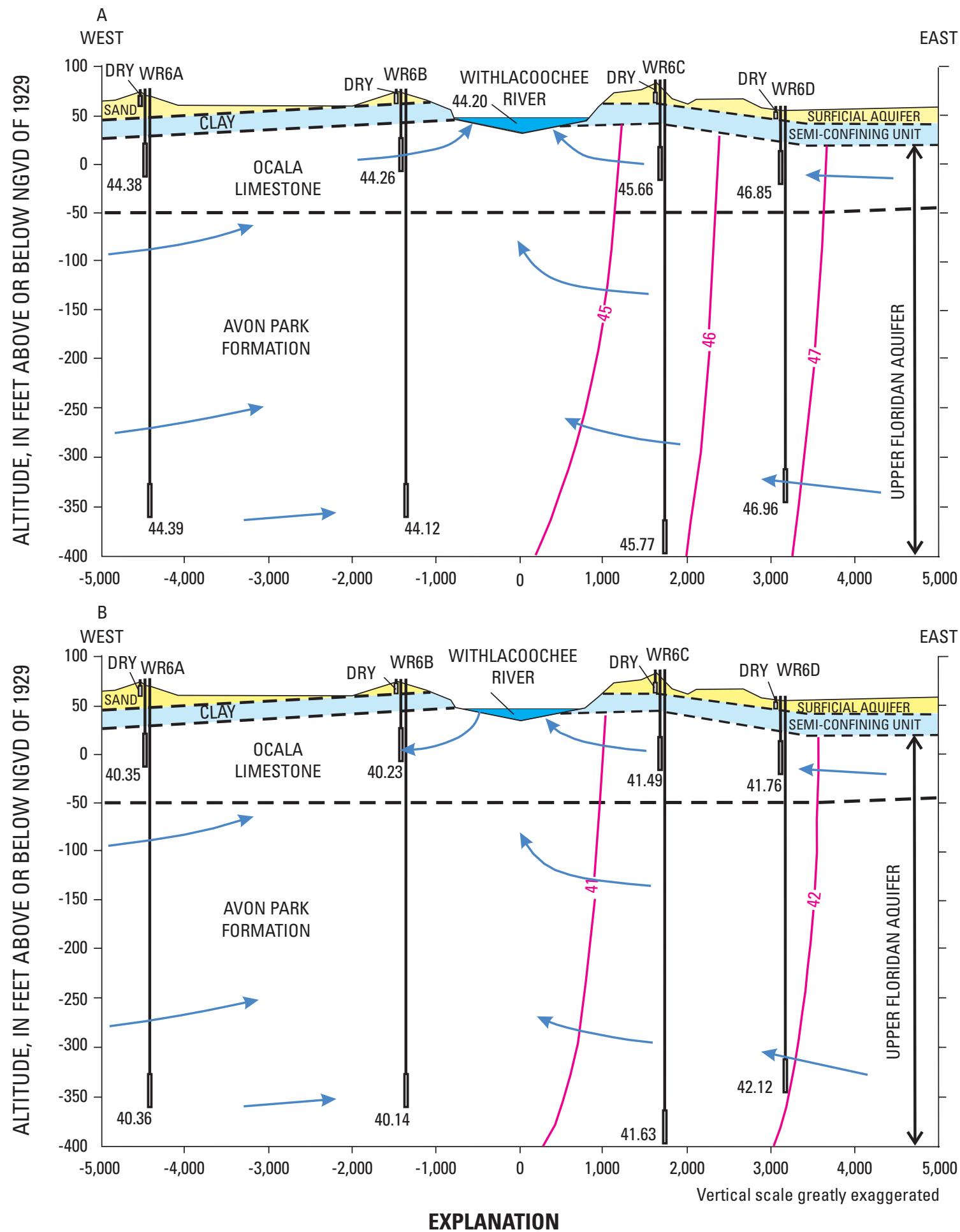

\footnotetext{
— 41- LINE OF EQUAL HYDRAULIC HEAD--In feet above NGVD 29 Contour interval is 1 foot

$\longleftarrow$ GROUNDWATER FLOW DIRECTION

42.12 HYDRAULIC HEAD - In feet above NVGD 29
}

Figure 22. Groundwater flow at the ROMP WR6 Withlacoochee River transect during the $A$, wet season, September 2005, and B, dry season, May 2006. Modified from Mallams (2007). 


\section{Summary}

The Withlacoochee River originates in the Green Swamp Area in north-central Polk County and flows northerly through seven counties, emptying into the Gulf of Mexico near Yankeetown, Florida. The river is one of only two rivers in the State that flow from south to north. This study does not include the entire Withlacoochee River watershed, it includes only the part of the watershed located between the headwaters in the Green Swamp and the USGS gaging station near Holder. The Holder station was chosen as the end of the study area because it is the farthest downstream gaging station where streamflow is not affected by fluctuating water levels from Lake Rousseau. The Withlacoochee River within the study area is about $108 \mathrm{mi}$ long and drains about $1,820 \mathrm{mi}^{2}$.

The hydrogeology of the Withlacoochee River watershed is relatively simple. A veneer of clastic material of variable thickness overlies a thick, near-surface sequence of carbonate rock. The most recent sediments are terrace deposits of Holocene and Pleistocene age consisting primarily of quartz sand. Where present, the surficial aquifer is located within these deposits. Sands, clayey sands, and clays of the Hawthorn Group of early Miocene age underlie the terrace deposits forming the intermediate confining unit. The intermediate confining unit separates the surficial aquifer from the Upper Floridan aquifer. Because of the karst nature of the underlying limestone, the confining unit is breached in many places and the degree of confinement between the Upper Floridan aquifer and the surficial aquifer is highly variable throughout the watershed. The underlying carbonate units that form the Upper Floridan aquifer can include the Suwannee Limestone of Oligocene age and the Ocala Limestone and Avon Park Formation of Eocene age.

The potential for the movement of water from the surface or shallow deposits to deeper deposits, or from deeper deposits to the shallow deposits exists throughout the Withlacoochee River watershed. During the study period, from October 2003 to March 2007, water-level altitudes in the deep Upper Floridan aquifer wells were higher than in the shallow Upper Floridan aquifer wells or surficial aquifer wells at 11 of the 19 paired or nested well sites included in the study, indicating potential for upward discharge. During most of the study, the surficial aquifer was dry. During a wet condition that occurred in March 2005, the surficial sediments at some sites became saturated, and the observed water table was higher than the potentiometric surface of the Upper Floridan aquifer, resulting in a temporary potential for recharge to the Upper Floridan aquifer. The transient reversal in head gradient also was observed at a site with paired shallow and deep Upper Floridan aquifer wells. Water-level altitudes in the shallow Upper Floridan aquifer or surficial aquifer wells were higher than in the deeper Upper Floridan aquifer wells at five other sites, indicating potential for recharge to the Upper Floridan aquifer. Water-level altitudes in the surficial and Upper Floridan aquifer wells at the remaining three sites were virtually the same, indicating little or no confinement at these sites and that the Upper Floridan aquifer was under water-table conditions.
Analysis of cumulative groundwater levels with time indicate a change in slope around 1983. An increase in slope indicated higher water levels after 1983. Analysis of cumulative water-level and cumulative rainfall data also show a change in slope around 1983, indicating groundwater levels are related to rainfall within the watershed.

Potentiometric-surface maps of the Upper Floridan aquifer for September 2005 and May 2006 indicate the pattern of groundwater flow in the aquifer did not vary greatly from season to season during the study. Hydraulic gradients are toward the river, and potentiometric contours bent upstream near the river from Dade City northward to Rital during September 2005, and from Dade City to Croom during May 2006 , indicating groundwater discharge to the river. Potentiometric contours also bent upstream near the river along the Outlet River from Lake Panasoffkee, indicating groundwater discharge to the surface water system. The slope of the potentiometric surface cuts across the river north of Croom, south of Dade City, and in the part of the Green Swamp within the basin, indicating little or no groundwater discharge from the Upper Floridan aquifer to the river in these areas.

Streamflow was observed in the lower sections of the Withlacoochee River from the Trilby station to the Holder station during the entire study period. During wet periods, direct runoff and input from tributaries contributed to streamflow in this part of the river. During dry periods, groundwater from the underlying Upper Floridan aquifer contributed substantially to the flow in the river. Streamflow at the upstream Dade City and Cumpressco stations was less constant, with no-flow days occurring periodically during dry periods. During wet periods, runoff causes streamflow peaks and recessions at upstream stations to be more rapid and extreme than at the downstream Trilby and Holder stations. Confinement between surficial deposits and the Upper Floridan aquifer is greater in the Green Swamp area than in areas farther downstream in the watershed.

Analysis of cumulative streamflow with time indicates a change in slope around 1970 for the Withlacoochee River at the Cumpressco, Trilby, and Holder stations. A second slope change is evident around 2000 at the Cumpressco and Trilby stations. The slope for the 1970-2000 period indicates a trend toward lower streamflow and coincides with the wetter pre- and drier post-1970 rainfall cycles related to the Atlantic Multidecadal Oscillation (AMO). The slope for the 2000-06 period is steeper than the slope for the 1970-2000 period, indicating a trend toward higher streamflow. Previous studies have examined rainfall and streamflow in Florida rivers in relation to the AMO, and also found them to be directly correlated.

Duration curves for the Withlacoochee River indicate that high flow events during the study period (2003-06) occurred less often than during the period between 1967 and 2006. However, discharge occurred in the mid- to low-flow range more frequently during the study period.

Synoptic streamflow measurements (seepage runs) were made along the Withlacoochee River during base-flow conditions in May 2004, April 2005, and April 2006. During most 
of the seepage runs, net seepage gains were identified for 16 of the 20 subreaches analyzed. The direction of exchange was mixed in the remaining four subreaches. River water recharged the groundwater system at these four subreaches during at least one seepage run.

The Withlacoochee River is generally a gaining stream. Groundwater discharges along most of the river channel, with total flows in the downstream direction increasing at greater rates than can be explained by tributaries or springflow contributions. Groundwater originates from shallower (younger) rocks in the upper reaches of the river and from deeper (older) rocks in the lower reaches of the river. Greater than 40 percent of the total river flow exiting the study area during seepage runs was from groundwater seepage. Tributary flow averaged about 30 percent, and spring flow averaged a little less than 30 percent of total river flow exiting the study area during seepage runs.

Water in the Withlacoochee River is slightly acidic in the headwater area in the Green Swamp, indicative of surface-water contributions. Specific conductance and $\mathrm{pH}$ as well as the concentrations of calcium, magnesium, sulfate, alkalinity, total dissolved solids, and strontium increase in the downstream direction, while the concentrations of chloride, sodium, potassium, and organic carbon decrease in the downstream direction, indicating an increasing influence of groundwater and a decreasing influence of surface water. River water changes from a sodium-calcium-chloride type to a calcium-bicarbonate type downstream from the Dade City station, and during low flow conditions, is similar to groundwater. Strontium isotope ratios indicate groundwater originates from shallower parts of the aquifer in the upper reaches of the river and from deeper parts of the aquifer in the downstream direction.

Mean annual base-flow estimates also indicate increasing groundwater discharge to the river in the downstream direction. Mean annual base flow estimated using standard hydrograph separation method assumptions ranged from about 4.7 to $5.1 \mathrm{in} / \mathrm{yr}$ or about 73 to 92 percent of total river flow; however, the standard assumptions may overestimate base flow because of low topographic relief and extensive wetlands located in the watershed. When the USGS HYSEP computer program was calibrated using a conductance mass-balance procedure, mean annual base flow estimates ranged from 0.6 to $2.7 \mathrm{in} / \mathrm{yr}$, or from 1.04 to 47.5 percent of total river flow.

Nine paired or nested and two single Upper Floridan aquifer wells were used to evaluate groundwater flow patterns near the river channel. River stage was consistently lower than groundwater heads in the Upper Floridan aquifer near the Cumpressco, Dade City, Wysong Dam, and Inverness gaging stations, indicating potential aquifer discharge to the river. The potential for both recharge and discharge between the Upper Floridan aquifer and the river exists at the Trilby, Nobleton, and Floral City gaging stations, where river stage was generally lower than groundwater heads except during periods of high streamflow. Four of the nested well sites make up the ROMP WR6 Withlacoochee transect, located near the Croom gaging station. During wet conditions, river stage was lower than groundwater heads and head gradients in the Upper Floridan aquifer were toward the river, indicating groundwater discharge to the river. During dry conditions, heads in the Upper Floridan aquifer wells were lower than river stage on the western side of the river, but were higher than river stage on the eastern side of the river. The Withlacoochee River may receive groundwater inflow from the east and lose water to the underlying aquifer to the west at this transect site during dry conditions.

\section{References Cited}

Anderson, W., 1980, Hydrology of Jumper Creek Canal, Sumter County, Florida: U.S. Geological Survey Water Resources Investigation Open-File Report 80-208, 41 p.

Anderson, W., and Laughlin, C.P., 1982, Geohydrology of the Floridan aquifer in the Withlacoochee Basin of the Southwest Florida Water Management District: U.S. Geological Survey Water Resources Investigation Open-File Report 82-331, 4 sheets.

Barry, R.M., Cavers, D.A., and Kneale, C.W., 1985, Recommended standards for digital tape formats: Geophysics, v. 40, p. $344-352$.

Basso, R., and Schultz, R., 2003, Long term variation in rainfall and its effect on Peace River flow in West-central Florida: Brooksville, Florida, Southwest Florida Water Management District, $33 \mathrm{p}$.

Bradner, L.A., 1988, Hydrology of the Floral City pool of Tsala Apopka Lake, west-central Florida: U.S. Geological Survey Water-Resources Investigations Report 88-4024, 44 p.

Calderon, Karynna, Dadisman, S.V., Yobbi, D.K., McBride, W.S., Flocks, J.G., and Wiese, D.S., 2006, Archive of digital boomer seismic reflection data collected during USGS field activities 04SGI01 in the Withlacoochee River of westcentral Florida, March 2004: U.S. Geological Survey Data Series 119.

Camp, S.C., and Barcelo, M.D. 1988, Wysong-Panasoffkee ground-water/surface-water project, Southwest Florida Water Management District, Brooksville, Florida, Resource Management Department, 112 p.

Cherry, R.N., Stewart, J.W., and Mann, J.A., 1970: General hydrology of the middle gulf area, Florida: Tallahassee, Florida Bureau of Geology Report of Investigations 56, $96 \mathrm{p}$.

Cooke, C.W., 1939, Scenery of Florida interpreted by a geologist: Florida Geological Survey Bulletin 17, 118 p.

Cooke, C.W., 1945, Geology of Florida: Florida Geological Survey Bulletin 29, 342 p. 
DePaolo, D.J., and Ingram, B.L., 1985, High-resolution stratigraphy with strontium isotopes: Science, v. 227, p. 938-941.

Enfield, D.B., Mestas-Nuñez,, A.M., and Trimble, P.J., 2001, The Atlantic Multidecadal Oscillation and its relation to rainfall and river flows in the continental U.S.: Geophysical Research Letters, v. 28, p. 2077-2080

Florida Department of Environmental Protection, 2005: Water Quality Status Report, Withlacoochee: Tallahassee, Florida, $227 \mathrm{p}$.

Ford, D.C., and Williams, P.W., 1989, Karst geomorphology and hydrology: London, Great Britain, Unwin Hyman Ltd., 601 p.

German, E.R., 1978, The hydrology of Lake Rousseau, westcentral Florida: U.S. Geological Survey Water Resources Investigations Open-File Report 77-126, 1 sheet.

Grubb, H.F., 1977, Potential for downward leakage to the Floridan aquifer, Green Swamp area, central Florida: U.S. Geological Survey Water Resources Investigations Report $77-71,1$ sheet.

Grubb, H.F., and Rutledge, A.T., 1978, Long-term water supply potential, Green Swamp area, Florida: U.S. Geological Survey Water-Resources Investigations Report 78-99, 78 p.

Halford, K.J., and Mayer, G.C., 2000, Problems associated with estimating ground water discharge and recharge from stream-discharge records: Ground Water, v. 38, no. 3, p. $331-342$.

Hem, J.D., 1985, Study and interpretation of the chemical characteristics of natural water ( $3 \mathrm{~d}$ ed.): U.S. Geological Survey Water-Supply Paper 2254, 263 p.

Hess, J., Bender, M.L., and Schilling, J.G., 1986, Seawater ${ }^{87} \mathrm{Sr} /{ }^{86} \mathrm{Sr}$ evolution from Cretaceous to present: Science, v. 231, p. 979-984.

Howarth, R.J., and McArthur, J.M., 1997, Statistics for strontium isotope stratigraphy: A robust LOWESS fit to the marine Sr-isotope curve for 0-206 Ma, with look-up table for the derivation of numerical age: Journal of Geology, v. 105, p. $441-456$.

Karst Underwater Research, Inc., 2006, Dobes Hole Springreconnaissance, discharge evaluation and preliminary exploration: Consultant's report prepared for the Southwest Florida Water Management District, Brooksville, Florida, 10 p.

Kelley, M., 2004, Florida river flow patterns and the Atlantic multidecadal oscillation: Ecologic Evaluation Section, Southwest Florida Water Management District, Brooksville, Florida.
Kendall, C., 1998, Tracing nitrogen sources and cycling in catchments, in Kendall, C., and McDonnell, J.J., eds., Isotope Tracers in Catchment Hydrology: Amsterdam, Elsevier Science B.V., p. 519-576.

Kerr, R.A., 2000, A North Atlantic climate pacemaker for the centuries: Science, v. 288, no. 5473, p. 1984-1986.

Kimrey, J.O., and Anderson, W., 1987, Reconnaissance of geohydrologic areas and 1981 low-flow conditions, Withlacoochee River basin, Southwest Florida Water Management District: U.S. Geological Survey Water-Resources Investigations Report 86-4203, 53 p.

Kinzelbach, W., Aeschbach, W., Alberich, C., Goni, I.B., Beyerle, U., Brunner, P., Chiang, W-H., Rueedi, J., and Zoellmann, K., 2002, A survey of methods for groundwater recharge in arid and semi-arid regions: Early Warning and Assessment Report Series, United Nations Environmental Program, Nairobi, Kenya, UNEP/DEWA/RS.02-2, 101 p.

Mallams, J.L. 2007, The geology, hydrology, and water-quality of the ROMP WR6-Withlacoochee transect well sites, Hernando and Sumter Counties, Florida: Southwest Florida Water Management District, Brooksville, Florida, Resource Conservation and Data Department, 290 p.

Metz, P.A., and Sacks, L.A., 2002, Comparison of the hydrology and water quality of a ground-water augmented lake with two non-augmented lakes in northwest Hillsborough County, Florida: U.S. Geological Survey WaterResources Investigations Report 02-4032, 74 p.

Miller, J.A., 1986, Hydrogeologic framework of the Upper Floridan aquifer system in Florida, and in parts of Georgia, South Carolina, and Alabama: U.S. Geological Survey Professional Paper 1403-B, 91 p.

Miller, R.A., Anderson, W., Navoy, A.S., Smoot, J.L., and Belles, R.G., 1981, Water-resources information for the Withlacoochee river region, west-central Florida: U.S. Geological Survey Water-Resources Investigation Report, 81-11, $130 \mathrm{p}$.

Oberg, K.A., Morlock, S.E.., and Caldwell, W.S., 2005, Quality-assurance plan for discharge measurements using acoustic Doppler current profilers: U.S. Geological Survey Scientific Investigations Report 2005-5183, 35 p.

Ortiz, A.G., 2005, Potentiometric surface of the Upper Floridan aquifer, west-central Florida, September 2005: U.S. Geological Survey Open-File Report 2006-1128, 1 sheet.

Ortiz, A.G., 2006, Potentiometric surface of the Upper Floridan aquifer, west-central Florida, May 2006: U.S. Geological Survey Open-File Report 2007-1032, 1 sheet. 
Pride, R.W., Meyer, F.W., and Cherry, R.N., 1961, Interim report on the hydrologic features of the Green Swamp Area, in central Florida: Tallahassee, Florida Geological Survey Informational Circular no. 26, 96 p.

Pride, R.W., Meyer, F.W., and Cherry, R.N., 1966, Hydrology of the Green Swamp Area in central Florida: Tallahassee, Florida Geological Survey Report of Investigations no. 42, $137 \mathrm{p}$.

Puri, H.S., and Vernon, R.O., 1959, Summary of the geology of Florida and a guidebook to the classic exposures: Florida Bureau of Geology Special Publication 5, 255 p.

Rabon, J.W., 1967, Inflow-outflow characteristics of Lake Rousseau (Inglis Reservoir) on the Withlacoochee River: U.S. Geological Survey Water-Resources Open-File Report $77-88,39 \mathrm{p}$.

Rantz, S.E., and others, 1982, Measurement and computation of streamflow: U.S. Geological Survey Water-Supply Paper 2175, 2 v., 631 p.

Rutledge, A.T., 1977, hydrologic reconnaissance of Tsala Apopka Lake, Citrus County, Florida: U.S. Geological Survey Water-Resources Open-File Report 77-89, 1 sheet.

Sacks, L.A., 1996, Geochemical and isotopic composition of ground water with emphasis on sources of sulfate in the Upper Floridan aquifer in parts of Marion, Sumter, and Citrus Counties, Florida: U.S. Geological Survey WaterResources Investigations Report 95-4251, 47 p.

Scott, T.M., 1988, The lithostratigraphy of the Hawthorn Group (Miocene) of Florida, Florida Geological Survey Bulletin 59, 148 p.

Scott, T.M., Campbell, K.M., Rupert, F.R., Arthur, J.D., Green, R.C., Means, G.H., Missimer, T.M., Lloyd, J.M., Yon, J.W., and Duncan, J.G., 2001, Geologic map of the State of Florida: Florida Geologic Survey Map Series 146.

Searcy, J.K., 1959, Flow duration curves-Manual of hydrology, part 2, low-flow techniques: U.S. Geological Survey Water-Supply Paper 1542-A, 33 p.

Searcy, J.K., and Hardison, C.H., 1960, Double-mass curves-Manual of hydrology, part 1, general surface-water techniques: U.S. Geological Survey Water-Supply Paper 1541-B, 65 p.

Sloto, R.A., and Crouse, M.Y., 1996, HYSEP: A computer program for streamflow hydrograph separation and analysis: U.S. Geological Survey Water-Resources Investigations Report 96-4040, 46 p.

Southwest Florida Water Management District, 1994, Final Report of the Withlacoochee River Work Group, Brooksville, Florida 289 p.
Southwest Florida Water Management District, 2001a, Withlacoochee River Watershed Plan 2001: Brooksville, Florida, $107 \mathrm{p}$.

Southwest Florida Water Management District, 2001b, Withlacoochee River Comprehensive Watershed Atlas: Brooksville, Florida.

Stewart, Mark, Cimino, Joseph, and Ross, Mark, 2007, Calibration of base-flow separation methods with streamflow conductivity: Ground Water, v. 45, no. 1, p. 17-27.

Stringfield, V.T., 1966, Artesian water in Tertiary limestone in the Southeastern States: U.S. Geological Survey Professional Paper 517, $226 \mathrm{p}$.

Taylor, G.F., 1977 Hydrology of Lake Panasoffkee, Sumter County, Florida: U.S Geological Survey Water-Resources Investigation Open-File Report, 77-88, 1 p.

Tetra Tech, Inc., 2004, Withlacoochee River Basin Feasibility Study: Hydrology and Hydraulics Data Collection and Review Final Report: Jacksonville, Consultants report prepared for the U.S. Army Corps of Engineers, 255 p.

Trommer, J.T., Sacks, L.A., and Kuniansky, E.L., 2007, Hydrology, water quality, and surface- and ground-water interactions in the upper Hillsborough River watershed, west-central Florida: U.S. Geological Survey Scientific Investigations Report 2007-5121, 73 p.

U.S. Geological Survey, variously dated, National field manual for the collection of water quality data: U.S. Geological Survey Techniques of Water-Resources Investigations, book 9, chap. A1-A9, available online at http://pubs.water. usgs.gov/twri9a

U.S. Geological Survey, 1989, Federal Glossary of Selected Terms-Subsurface-water flow and solute transport: U.S. Geological Survey Office of Water Data Coordination, Ground Water Subcommittee of the Federal Interagency Advisory Committee on Water Data, 38 p.

Vernon, R.O., 1951, Geology of Citrus and Levy Counties, Florida: Tallahassee, Florida Geological Survey Bulletin 33, $256 \mathrm{p}$.

White, W.A., 1958, Some geomorphic features of central peninsular Florida: Tallahassee, Florida Geological Survey Bulletin 41, 92 p.

White, W.A., 1970, The geomorphology of the Florida Peninsular Florida: Tallahassee, Florida Geological Survey Bulletin 51, $164 \mathrm{p}$.

Yon, J.W., and Hendry, C.W., Jr., 1972, Suwannee Limestone in Hernando and Pasco Counties, Florida: Tallahassee, Florida Geological Survey Bulletin 54, part I, 42 p. 